\title{
Edition and translation
}


[0] siddhaṃ namo ratnatrayāya |

[1.1] atha bhagavān vārāṇasyāṃ mahānagaryāṃ viharati sma | mahatārthakaraṇena sattvānāṃ dharmaṃ deśayati sma | yad uta sarvāśāmanorathaparipūrṇakalyāṇakārakam | mahatā parṣatsaṃnipāte takṣakapūrvaṃgamanāgarājaparṣadā | mahatā devamānuṣaparṣadā |

[1.2] atha navanagare viṣnudatto nāma brāhmaṇa āḍhyo mahādhano mahābhogaḥ prabhūtavittopakaraṇasaṃpanno vedavedāngapāragaḥ | mantrapravartako mantrasādhakaḥ | sa punaḥ punar nāgān āvāhayanti | agnihotraṃ juhoti | tasya brāhmaṇasya sasyakāle udakakșayamati prādurabhūt | sa cāhaṃkāraśabdena mantrapadānumatena evaṃ kathayati | varṣadhārā-mutș̣jāmy aham | nāgān āvāhayiṣyāmi | tenāgnihotraṃ prajñaptaṃ tilataṇụulasarṣapakațutailābhyaktam juhoti | tena kasyacid dușțanāgasya pratikṛtirūpaṃ kṛtam | tenāyomayaṃ kỉlakaṃ parijapya tatas tasya nāgasya mūrdhni dattam | sa ca nāgo mūrdhānaṃ sphuțati | mahatīṃ vedanām anubhavati | sa ca nāgo mahatā krodhena kruddhatarạ̣ | tatạ̣

kṣaṇalavamuhūrtena svaśarīraṃ nāgaplavanavegena mahāpị̄ānvitạ̣ | tatas tai raśmayo svaśarīrād utșrșțās tena tasya brāhmaṇasya kṣetrāṇi dagdhāni mahāpịdena saṃchādya tasya mahatī agnivarṣadhārā brāhmaṇasya śarīre nipātitā | sa ca brāhmaṇa agnihotrāṇy utș̣jya atrāṇo aśaraṇa aparāyaṇo na kaścit trāâ̄sti | sa ca bhagavantạ̣ śaraṇaṃ trāṇam parāyaṇaṃ gaveșya vipralāpaṃ kartum ārabdhạ̣ | bhagavato 'ntikam anudhāvati | yena bhagavāṃs

1 siddham] B; om $\mathrm{AD}\langle\mathrm{A} 28 \mathrm{v}\rangle\langle\mathrm{B} 25 \mathrm{r}\rangle\langle\mathrm{D} 25 \mathrm{r}\rangle \quad 3$ mahatārthakaranena...sma] B omits this sentence. - mahatārthakaraṇena] D; mahatā karaṇena A, om. B • sma] D; om. AB 4 -manoratha-] AB; -manortha- D •-kārakam] conj.; -kārakāḥ ABD 5 -rāja-] AB; -rājya- D, om. Tib • mahatā] AD; mahatyā B • -mānuṣaparșadā] corr.; -mānuṣapadā A, -mānuṣoparṣadā B, -mānuṣāparṣadā D 6 navanagare] $\langle\mathrm{D} 25 \mathrm{v}\rangle \quad$ • āḍhyo] AB; ājño D • mahādhano] BD; mahādhana- A 7 mahābhogaḥ] AB; mahābhaḥ D • -samppanno] <A29r> 8 nāgān] corr.; nāgā A, nāgam BD • āvāhayanti] BD; vāhayanti A 10 evaṃ] BD; traca A • kathayati] D; kathayanti A, kathayet B 11 utș̣jāmy] BD; utș̣jy A • nāgān] AD; nāgānām B 12 -tailābhyaktaṃ] corr.; -trailābhyaktvā $\mathrm{A}$, tailābhyuktaṃ $\mathrm{B}$, -tailābhyuktā D • kasyacid] D; kasyaci $\mathrm{A}$, kasyacit $\mathrm{B}$ 13 parijapya] $\mathrm{BD}$; parijapet $\mathrm{A} \bullet$ tatas] $\mathrm{BD}$; om. $\mathrm{A} 14$ dattam] $\mathrm{AD}$; ++ $\mathrm{B}\langle\mathrm{B} 25 \mathrm{v}\rangle \bullet$ sa ca] $\mathrm{AD}$; ++ B • mūrdhānaṃ] B; mūrdhā A, mūrdhāṃ D • sphuțati] D; sphoțati A, sphațati B <A29v > • mahatīm] BD; mahati A 15 anubhavati] D; anabhavati A, anubhavanti B • sa ca nāgo] BD; sarvanāgo A • mahatā] D; mahāntā A, mahato B • krodhena] BD; krodhenu A <D26r $>$ • kruddhatarah] D; kruddhatara A, krudhanarah B 16 -plavanavegena] BD; -praveśena A • mahāpị̄̂ānvitaḥ] AB; -tāḥ D • tai] BD; yai A 18 mahāpị̣ena] em.; mahāpītena $\mathrm{AD}$, mahāyitena B 19 utsṛjya] AB; utș̣ D • atrāṇo] BD; atrāṇai A • aparāyaṇo] D; aparāyaṇaị A, aparāyaṇaudha B 20 kaścit] BD; kaścin A • trātāsti] BD; trātānti A • gaveșya] B; gaveșye A, gaveșā D 21 ārabdhaḥ] AB; ārapno $D$ • anudhāvati] <A30r> 
[0] Veneration to the Three Jewels

[1.1] The Bhagavān was dwelling in the great city of Vārāṇasī. Providing great benefits he was teaching the Dharma to beings, namely the producer of virtue, fulfilling ${ }^{1}$ all hopes and wishes. ${ }^{2}$ [He was] in an assembly-gathering, with a great assembly of Nāgas lead by Takșaka. ${ }^{3}$ With a great assembly of Devas and humans.

[1.2] Now there lived a Brahmin called Viṣnudatta in Navanagara. ${ }^{4} \mathrm{He}$ was wealthy with great riches, great revenues; he was endowed with copious acquisitions and means of subsistence. He had mastered the Vedas and Vedāngas. ${ }^{5}$ He was a mantra-reciter and mantra-practitioner. He summoned Nāgas again and again. He sacrificed fire oblations. In the crop-growing season he experienced a lack of water. With words of self-conceit, [possessing] approval [to use] mantrapadas he said, "I am going to send forth rain showers and summon Nāgas." He sacrificed the prescribed fire oblation with sesame seed, ${ }^{6}$ rice grain and mustard seed anointed with pungent oil. He prepared an image-form ${ }^{7}$ of a certain harmful Nāga. He enchanted an iron stake and placed it on the head of that Nāga. The head of the Nāga burst and it felt great pain. The Nāga became extremely angry with great fury. Then in a moment, an instant, a short time, the Nāga's body was overcome with great pain by the intensity of swaying. ${ }^{8}$ Then because of this rays came forth from its body and the fields of the Brahmin were burnt. The Nāga in great pain threw a great fire rain shower upon the Brahmin's body enveloping it. The Brahmin discontinued the fire oblation, became defenceless, deprived of a refuge and last resort and there was nobody to save him. He started to cry out seeking refuge, defence and a last resort at the Bhagavān. He ran to the

1 Paripūrṇa, "full of", seemingly stands for paripūraka, "fulfilling", as also supported by the Tibetan translation.

2 This compound, if emended to -kārakah, may also refer to the Bhagavān.

3 For Takșaka, see Vogel (1926: 203-07).

4 It is unclear whether Navanagara or "New Town" is a suburb of Vārānasīi or a place further away. I have not been able to locate this settlement in other sources. The Tibetan translation does not mirror this name.

5 I.e. śikṣā, chandas, vyākaraṇa, nirukta, jyotișa and kalpa.

6 Sesamum indicum.

7 The words pratikrti, pratima and rūpa are translated as "image" throughout the text, referring most likely to a three-dimensional representation which may also be called a statuette or effigy. Often there is no word given for such an object; the text simply states that, for example, a Garuda should be made. The verb likh, on the other hand, clearly refers to painting a twodimensional image.

8 It is not completely clear whether this sentence refers to the body of the Nāga or the Brahmin. 
tenopasaṃkrānto bhagavatạ̣ pādayor nipatyaivam āha | trāyatu bhagavān trāyatu sugatah | tcatuṣugata† caṇḍanāgo mama jīvitavināśaṃ kartukāmo na kaścit trātāsti |

[1.3] atha bhagavāṃs taṃ mahābrāhmaṇaṃ samāśvāsyaivam āha | mā bhayaṃ hi mahābrāhmaṇa ahạ̣ te śarạ̣aṃ gatị̣ parāyaṇaṃ bhaviṣyāmīti | tūṣṇīm 5 āsthitạ̣ |

[1.4] atha khalu vajrapāṇir mahāyakṣasenāpatir bhagavantam etad avocat | paśya bhagavan pratyakṣībhāvena dușțanāgena sarvasasyāni vināśitāni | tat katham paścime kāle paścime samaye tvayi nirvṛte sarvasattvānāṃ gatih syād iti | tad bhagavān bhāṣantu atha sasyaparipālanam | nāganivāraṇaṃ sarvasasyārtham | sarvasasyāni samarpitāni bhaviṣyanti | saṃrakṣitāni pravardhitāni bhaviṣyanti |

[1.5] atha bhagavān vajrapāṇim guhyakādhipatim etad avocat | asti vajrapāṇe nāgapratisarikāvagṛhītavajrā nāma dhāraṇi tathāgatahṛdayamudrā pūrvakais tathāgatair arhadbhị̣ samyaksaṃbuddhair bhāṣitā | aham apy etarhi bhāṣiṣye | yena śīghraṃ pị̣̂apratiṣedhanārthāya sarvasasyapratipālanaṃ bhaviṣyati | svārakṣitāni bhaviṣyanti | sarvanāgānāṃ sīmābandho bhaviṣyati | mahāgniparvataprāgbhārāḥ samantena caturdiśạ̣ mahāgnijvālāpațalameghagaruḍavegapakṣivijṛmbhitam nāmātra pațalam ākāśam saṃchādayanti | sarvapuṣpaphalasamrakṣaṇāya tiṣthati | yena sarvanāgādayaḥ samprajvalitā bhaviṣyanti | sarvaduṣṭanāgā vinaśyanti |

1 bhagavatah] AB; -toḥ D • trāyatu] BD; -antu A 2 trāyatu] BD; -antu A • catuṣugata] A; caturṣugata $\mathrm{BD}$, om. Tib • mama jīvitavināśaṃ] BD; sama jivināśaṃ A • -kāmo] ABDpc; -mokā Dac 3 trātāsti] AD; trātā nāsti $\mathrm{B}<\mathrm{D} 26 \mathrm{v}\rangle \quad \mathbf{4}$ bhagavāṃs] $\mathrm{D}$; -vaṃs $\mathrm{AB}$ • samāśvāsyaivam] $\mathrm{AD}$; samāśvāsevam B • mā] <B26r> $\quad 5$ śaraṇaṃ] BD; laraṇa A $\quad 8$ pratyakṣî̉bhāvena] D; prakṣībhāvena $\mathrm{A}$, pratyakșīnubhāvena $\mathrm{B} \quad \mathbf{9}$ paścime $\left.\left.^{1}\right]<\mathrm{A} 30 \mathrm{v}\right\rangle \quad$ • sarvasattvānāṃ] $\mathrm{AB}$; sattvānāṃ D • gatiḥ] D; śayati A; śayatiḥ B • syād] AD; tasyād B 10 bhagavān] BD; bhagavan A • bhāṣantu atha] B; māmantra A, bhāṣanta D nāganivāraṇaṃ] B adds: sarvasasyāni vināśitāni | tat kathaṃ paścime kāle paścime samaye tvayi nirvṛte sarvasattvānā śayatị̣ syād iti | tad bhagavān bhāṣantu atha sasyaparipālanam | nāganivāraṇaṃ (dittography) 11 sarvasasyārtham] AD; sarvasasyāthā B • samarpitāni] D; sarpitāni A, -m-atapitāni B 12 bhavișyanti] BD; bhavanti A 14 -vagṛhīta-] AD; -ca++īta- B $\langle$ B26v $\rangle$ • dhāraṇī] $\langle$ D27r $\rangle$ 15 bhāșișye] BD; bhāṣișyate A 16 śīghraṃ] D; śrīrgha A, śīpra B • -pratipālanaṃ] D; -patimālanaṃ A, -pratipālanaḥ B <A31r $>17$ svārakṣitāni] B omits a longer part from here and continues at [3.8] • sīmābandho] D; sīmāba A • bhavișyati] D; -anti A 19 -vij̣̣mbhitaṃ] em. Szántó; -vișambhitam A, -vihyambhitaṃ D • nāmātra pațalam] D; nānātrayasam A 20 saṃchādayanti] A; -ati D • -rakṣaṇāya] D; -vakṣaṇāya A 21 sarvanāgādayaḥ] D; -yai A • -nāgā] A; -nān D 
Bhagavān, went up to him and having bowed down at his feet said, "May the Bhagavān save me, may the Sugata save me. A fierce Nāga is desirous of destroying my life and there is nobody to save me."

[1.3] Then the Bhagavān comforted the Great Brahmin and said, "Fear not, Great Brahmin, I shall be a refuge, shelter and last resort for you." Then he remained silent.

[1.4] Then Vajrapāṇi, the great leader of Yakṣas, addressed the Bhagavān, "Look, Bhagavān, clearly all crops have been destroyed by the harmful Nāga. How will there be shelter for all beings in the last time, in the last age, ${ }^{9}$ after you have departed? Therefore let the Bhagavān speak about the protection of crops and the averting of Nāgas for the sake of all crops. [Thus] all crops will be provided, protected and increased."

[1.5] Then the Bhagavān addressed Vajrapāni, the Lord of the Guhyakas, ${ }^{10}$ "Vajrapāṇi, there is the dhāraṇi called the Nāga Assailing and Impeding Vajra, that is the seal of the heart of the Tathāgatas, uttered by former Tathāgatas, Arhats and Perfectly Awakened Ones. ${ }^{11}$ I will also utter it now. By this there will be a rapid guarding of all crops for the sake of warding off damage. They will be well protected. There will be a sealing of the boundaries for all Nāgas: the slopes of the great fire-mountain ${ }^{12}$ will completely cover the four directions and the great fire blaze mass cloud that is the expanded [wings] of the Garuda speed bird, called a great mass, ${ }^{13}$ will cover the sky. It is there for the protection of all flowers and fruits. All Nāgas and so on will be burnt by that. All harmful Nāgas will be destroyed."

9 For references to discussions of the decline of the Dharma, see Hidas (2012: 218).

10 Guhyakas are a class of Yakșas. See Raven (1988) and DeCaroli (2004).

11 For an elucidation of this seal, see Harrison (1990: 191-92).

12 This is unlikely to refer to the mountain around the edge of the universe as it is made of iron and called Cakravāḍa; the other, inner seven ranges are made of gold (Sadakata 1997: 26; Kloetzli 1983: 24).

13 "Called a great mass" looks superfluous and may reflect textual corruption. 
[1.6] atha vajrapāṇir mahāyakṣasenāpatir bhagavantam etad avocat | nirdiśatu bhagavān mahādhāraṇīmantrapadaṃ sarvasattvānāṃ hitaṃ kuru iti |

\section{[1.7] atha bhagavān idaṃ hṛdayaṃ bhāṣate sma |}

namo bhagavate buddhānām | namo bhagavate saākyamunirājāya | oṃ jvala jvala giri bhavanaṃ dīptavega mahācaṇḍahṛdayasphālani | huru huru hana hana daha daha paca paca pācaya sarvasasyanāśakanāgakulavaṃśam | dhara dhara pravaracaṇḍavega mahābalaparākrama sphūriitaraudravaktra | matha matha jvālāmālādhāriṇi caṇdavegavati pravaravimānadhāraṇi hūṃ hūṃ balavati vegavati visara visara visaranti sarvasasyatṛnagulmoṣadhivanaspatipuṣpaphalapatrasaṃdhāraṇi | apasarantu sarvanāgadoṣāh | sarvabhavanavigatavegavati svāhā | hūṃ hūṃ phaṭ | nāgavidāriṇi phaț | jvālāmālini phaṭ svāhā |

\section{[1.8] samanantarabhāṣitā bhagavatā iyaṃ vidyā}

sarvanāgasarvaduștopadravanāśakā | mahānāgāḥ sarve śīrṣarogāḥ samvṛttāḥ | klinnakāyā durgandhapūtikakāyāḥ saṃvṛttāḥ | bhagavataḥ pādayor nipatyaivam āhuh | atidāruṇāni bhagavan mantrapadāni bhāṣitāni | mama bhagavann aparādhaṃ jānīte | api tu bhagavan dușțavidyādhareṇāhaṃ paribhūyāmi | tāḍayāmi visarjayāmi | tadā bhagavan dușțanāgāḥ kṣubhanti | tadā sasyāni nāśayanti | puṣpaphalāni nāśayanti | aśaniṃ pātayanti | šitavātān saṃkṣobhayanti | ativṛștim anāvṛ̦țịm akālavṛștịm pātayanti | api tu bhagavan maitrīvihāriṇā vidyādhareṇa mantravādinā bhavitavyam | maitrīsattvasaṃn̄hena bhavitavyam | maitrīkhaḍgahastena bhavitavyam |

1 -patir] A; -patim D • nirdiśatu] em.; dvir dvekșatu A, nirdakṣatu D 2 iti] <A31v> 3 bhagavān] D; bhagavānn A $\langle$ D27v $>\quad 4$-munirājāya] A; -rājāya DTib 5 bhavanaṃ] D; bhagavan A • -caṇda-] D; -candra- A 6 pācaya] D; pāraye A, om. Tib • -sasya-] DTib; -śalya- A • -nāśaka-] conj.; -nāśāye A, -nāśaya D 7 -caṇḍavega] A; -ṇdavega D 8 -inị] D; -aṇi A 10 -saṃdhāraṇi] <A32r> 12 -vidāriṇi] D; -dāriṇi A $\bullet \quad$ phaț²] <D28r $>13$ bhagavatā] D; om. A 14 -opadravanāśakā] D; -opadranāśakā A 16 atidāruṇāni] A; atidaruṇāṇani D • bhagavan] ApcD; bhagavan duștavidyāparaṇaṃ Aac 17 aparādhaṃ] A; aparāddhaṃ D • jānīte] D; jāte A • -vidyādhareṇāhaṃ] D; -vidyāparaṇaṃhaṃ A <A32v> 18 -bhūyāmi] D; -bhūyāni A • tāọayāmi] D; tāḍayogi A • visarjayāmi |] AacD; visarjayāmi | atimabhi+phayāśrayāguṇa Apc (marginal addendum) • bhagavan] D; bhagan A • kṣubhanti] D; kṣubhavanti A 21 mantravādinā] D; mantrapadāni $\mathrm{A}<\mathrm{D} 28 \mathrm{v}>\bullet$ bhavitavyam] D; bhāṣitavyam A 
[1.6] Then Vajrapāṇi, the great leader of Yakṣas, addressed the Bhagavān, "Let the Bhagavān teach this great dhāraṇi-mantrapada and do a service for all people."

[1.7] Then the Bhagavān spoke this heart[-mantra],

"Veneration to the glorious Buddhas. Veneration to the glorious king Śakyamuni. Om flame, flame, giri the dwelling, O Blazing Speed, $O$ the One who Shakes the Heart of the Greatly Fierce One, huru, huru, kill, kill, burn, burn, roast, roast, bake all crop-destroying lineages of the Nāga family, hold, hold, O Best Fierce Speed, $O$ the One of Great Strength and Courage, $O$ the One with a Throbbing and Wild Face, stir, stir, $O$ the One who Wears a Flame Garland, $O$ the One with Fierce Speed, $O$ Holder of the Best Flying Palace, hūm, hūm, O Powerful One, O Swift One, spread, spread, $O$ the One who Spreads, O Preserver of All Crops, Grass, Bush, Herbs, Trees, Flowers, Fruits and Leaves, may all harm caused by Nāgas retreat, O Swift One who has Gone from all Residences svāhā, hūm hūm phaț, O the One who Tears Nāgas Apart phaț, $O$ the One with a Flame Garland phaț svāhā."

[1.8] Immediately after the Bhagavān had uttered this spell, the destroyer of all Nāgas and all malefactors and calamities, all the great Nāgas got headaches, their bodies became putrid, stinking and foul-smelling. They fell at the feet of the Bhagavān and said, "O Bhagavān, extremely dreadful mantrapadas have been uttered. O Bhagavān, my offence is known. ${ }^{14}$ But, O Bhagavān, I was overpowered by the hostile spell-master and I stroke back and emitted [the fire]. Then, O Bhagavān, the hostile Nāgas become agitated and destroy crops. They destroy flowers and fruits. They send down thunderbolts. They stir up cold winds. They send down excessive rain, a lack of rain and untimely rain. However, O Bhagavān, the spell-master, the reciter of spells, should abide by friendliness. He should have the armour of a friendly being. He should have the sword of friendliness in his hand. ${ }^{15}$ [For] friendliness pacifies the hostile.

14 The syntax of this sentence is somewhat problematic. Bhagavann could perhaps be emended to bhagavān with jānite. Or should jāte be corrected to jātam? While this paragraph refers back to the opening narrative featuring only one Nāga, note the fluctuation between the use of the first person singular and plural.

15 For another reference to "the sword of friendliness", see Mahāpratisarā [37]. 
maitryā sarvaduṣṭā niśāmyanti | api tu bhagavann adyaprabhṛty ahạ̣ tathāgatasya purataḥ pratijñāṃ kariṣyāmi | yatrāyaṃ vidyādhararājā pracariṣyati na tatra bhagavan bhūyo nāgā upadravaṃ kariṣyāmaḥ | yatrāyaṃ hṛdayadhāraṇi rakṣāyāṃ kṛtāyāṃ paritrāṇaṃ parigrahaṃ paripālanam sīmābandham maṇḍalabandham pratisarāyāṃ kṛtāyāṃ tasya vayam bhagavan satatasamitam sarvopadravān nivārayiṣyāmah |

[1.9] atha bhagavāṃs teșāṃ nāgādhipatīnāṃ sādhukāram adāt | sādhu sādhu bhujagādhipatayaḥ | evaṃ yuṣmābhị̣ karaṇiyam | surakṣitair yuṣmābhir jambudvīpam anurakṣitavyam iti |

[1.10] athāta upacāravidhim pravakṣyāmi sarvakarmakaraṃ śubham | sasyapị̣ākāle kṣubhanti | tadā vidyādhareṇa kṣetramadhye 'raṇye vā caturasraṃ mạ̣ḍalakam kartavyam | catvāraḥ pūrṇakumbhāḥ sthāpayitavyāḥ | puṣpāvakīrṇam kartavyam | sapta rūpakavalayaḥ kartavyāḥ | tạ̣ḍulavalayạ̣ | ekaikarūpakam ekaviṃśatirūpakaṃ kartavyam | bhaktapāyasakṛsaradadhikṣiraṃ saṃsthāpayitavyam | phalapuṣpaṃ sthāpayitavyam | catvāro ghațikāḥ sthāpayitavyāḥ | saktupramukhā mahābalipūrvam sthāpayitavyā | madhye mạ̣ḍalake kuṇḍạ sthāpayitavyam | pañcagavyaṃ kṣīram udakam pūrayitavyam | sarṣapalājā prakṣeptavyā | ṣaștivārān mantraḥ parijaptaḥ khadirakīlakāni catvāri ayomayāni | ekakīlakam așțāṅgulapramāṇam sarveșāṃ kartavyam | caturṣu koṇeṣu maṇụalakasya kapilagomayā catvāro nāgāḥ kartavyāḥ | khadirakīlakā ca hṛdayasthā sakalaṃ nikhantavyam | aștottaraśatam mantram parijaptavyam | pūrvasyāṃ

\footnotetext{
1 maitryā] D; sarvai maitryā A • bhagavann] D; -van A 2 puratah] $<$ A33r $>$ • karișyāmi] D; kariṣyati A $\quad 3$-yāmaḥ] D; -yāme A $\quad 4$ hṛdayadhāraṇī] D; hṛyadhāraṇī A • -pālanaṃ] A; -pālanāyāṃ D 5 maṇụalabandhaṃ] D; om. A 6 sarvopadravān] D; sarvopadra A • nivārayișyāmaḥ] D; vārayișyāmaḥ A $\quad \mathbf{8}$ bhujagādhipatayaḥ] D; bhujaṃgādhipatayaḥ A • karaṇiyam] <D29r $>10$ athāta] D; athāca A • -vidhiṃ] ADpc; -vidhaṃ Dac <A33v > 11 -kāle kṣubhanti] D; kāleșu bhavanti ATib 12 kartavyam] D; -vyā A 13 rūpakavalayaḥ] A; rūpaṃkamvalayaḥ D • taṇdulavalayaḥ] D; taṃțaravayoḥ A 14 -rūpakaṃ] D; -pakaṃ A 15 -kṛsara-] D; -vṛsara- A, om. Tib • -sthāpayitavyam] Dpc; -sthāpayetavyam A, -sthāpayivyam Dac 16 ghațikāḥ] A; -āṃ D • saktu-] A; sahyu- D 17 madhye] <A34r> 18 pūrayitavyam] D; pūvayitavyam A • -lājā] D; -lājākṣata A • prakṣeptavyā] A; kṣeptavyāḥ D 19 -kīlakāni] A; -kirakīlakāni D • catvāri] <D29v> 20 caturṣu koṇeșu] D; catukoṇeșu A 21 -kīlakā] A; -kīlakam D • sakalam] D; sasakara A
} 
However, O Bhagavān, from today on I make a vow in the presence of the Tathāgata. Wherever this spell-holder king will circulate, ${ }^{16}$ there, 0 Bhagavān, the Nāgas will not make calamities again. Wherever this heart-dhāraṇi is used for protection, [there is] rescue, shelter, safeguard and the sealing of the boundaries and sealing of the mandala. Where an amulet-cord ${ }^{17}$ is made, for that person, $\mathrm{O}$ Bhagavān, we will constantly ward off all calamities.”

[1.9] Then the Bhagavān praised those Nāga chiefs, "Well done, well done, $O$ Serpent chiefs. You should act like this. You should protect Jambudvipa with good protection.

[1.10] "Now I shall teach the offering manual which is auspicious and can bring about any effect. At the time of crop damage the [Nāgas] are agitated. Then the spell-master should prepare a square mandalaka in the middle of the field or forest. Four filled jars should be placed [in the four directions]. Flowers should be scattered. Seven coiling figures ${ }^{18}$ should be made and rice spirals. Twenty-one figures should be prepared one after the other. Boiled rice, milk rice, a dish of rice and peas, ${ }^{19}$ yoghurt and thickened milk should be placed. Fruits and flowers should be placed. Four jars ${ }^{20}$ should be placed. Preceded by a great offering barley-meal should be placed as foremost. A bowl should be placed in the middle of the mandalaka. It should be filled with the five products of the cow, ${ }^{21}$ thickened milk and water. Mustard seeds and parched grain should be cast. Four stakes made of khadira $\operatorname{wood}^{22}$ and iron ${ }^{23}$ [should be placed] after they have been enchanted with the mantra sixty times. All stakes should measure eight angulas. $^{24}$ There should be four Nāgas made of brownish cow dung in the four corners of the mandalaka. Stakes made of khadira wood should be driven into the ground over their heart completely. The mantra should be recited 108 times. A seven-headed Nāga should be placed in the eastern direction. An eight-headed

16 For occurrences of this stock phrase, see Hidas (2012: 144).

17 For pratisarā, see Hidas (2012).

18 Note that rūpaka also means coin.

19 Monier-Williams (1899: 308) (henceforth MW): “a dish consisting of sesamum and grain (mixture of rice and peas with a few spices)."

20 Note that the Tibetan version reflects a variation between "jars" and "bells" ghața and ghanțāa in Sanskrit. Cf. [6.5].

21 MW 575: "milk, coagulated or sour milk, butter, and the liquid and solid excreta."

22 Khadira wood (Acacia catechu) is often used for stakes, as attested in various texts. See also Klein (2018: 243).

23 There is also mention of iron stakes in section [1.2].

24 MW 8: "a finger's breadth, a measure equal to eight barleycorns.” 
saptaśīrṣakaṃ nāgaḥ sthāpayitavyaḥ | paścimāyāṃ diśi așțaśīrṣakam | dakṣiṇasyāṃ pañcaśīrṣakam | uttarasyāṃ triśīrṣakam | madhye maṇḍale navaśīrṣako nāgaḥ sthāpayitavyaḥ | catvāro dhūpakaṭacchukāḥ sthāpayitavyāḥ | pañcamo madhyamaṇụale | lājāsarṣapamiśrena ekaviṃśati vārān parijapya caturdiśam prakṣeptavyāḥ | iyam dhāraṇī likhya caturṣu mạ̣ḍalakoṇeṣu dhvajāgre 'varopayitavyāḥ | kṣetramadhye ca sthāpayitavyāh | ārāmamadhye ca sthāpayitavyāḥ | sahasthāpitamātreṇa samantāc caturdiśam mahāparvataprāgbhārasīmābandhaḥ kṛto bhavati |

[1.11] yāvat kīlakaṃ noddhriyate tāvat mahāsīmābandho bhavati | sarvasasyāni sarvapuṣpaphalāni svārakṣitāni bhaviṣyanti | antaśa ekapatram api na śuṣyanti | 10 kiṃ punạ̣ śākhāntāḥ śuṣyanti | sarvaprāṇakajātayaḥ mrgapakṣī tāni sarvāṇi tụ̣ḍe bandham bhaviṣyati | na śakyam vināśayitum | nașțā te 'pi punar api tejāḥ pratilabhante | punar api balapuștitejā upasaṃkrāmanti | sa ca kuṇụạ̣ samantāc caturdiśaṃ kṣetrārāmasahitāni siñcitavyāni | sarvaprāṇakā vinaśyanti | sarpamūṣikānakulasūcīromajațilamaṇụūkadaṃśamaśakaśalabhādipakṣigaṇā vinaśyanti | sarve krimiyo vinaśyanti | antaśah patamgaprabhṛtayo na bhavanti | kadācana na śakyaṃ vināśayitum | yāvat saṃsvedajā upapādukā aṇḍjā-m-api śilāpuṣpasamudbhūtāḥ prāṇakajātayo na prabhavanti yāvat kīlakạ̣ noddhriyate | na ca vividhanāgadoṣā bhūyah prasahiṣyanti | yāvat kīlakaṃ noddhriyate | kṣemasubhikṣāni sarvasasyā puṣpaphalāni pariniṣpadyante | surasāni mṛdūni bhaviṣyanti | sarvanāgāḥ satatasamitaṃ rakṣāvaraṇaguptaye samvidhāsyanti |

\footnotetext{
1 -vyaḥ] D; -vyam A • aștaśīisṣakam] <A34v> 3 -śīrṣako] A; -śīrṣo D • -vyaḥ] D; -vyam A 4 -miśreṇa] D; -miśraveṇa A • parijapya] A; pavijapya D 5 prakṣeptavyāh] A; kṣeptavyāḥ D 6 ca $\left.^{1}\right]$ D; om. A • sthāpayitavyāḥ] $<$ D30r $>\bullet$ ārāma-] conj. Tib; sahāna- A, sāhīna- D • -madhye] D; -mane A 8 -bandhah] D; -bandham A • bhavati] <A35r $>9$ noddhriyate] corr.; nodhriyate AD 10 svārakṣitāni] D; svarakhitāni A • ekapatram api] D; ekapatra A 12 tuṇ̣̣e] D; kuṇụaA • vināśayitum] D; vināśansitum A 13 pratilabhante] D; -ate A • kuṇụaṃ] A; kuṇ̣ạ̣ D 14 samantāc] D; samantā A • sarva-] D; sarve A 15 -jațila-] A; -jațāla- D $\langle$ A35v $\rangle\langle$ D30v $\rangle$ • -śalabhādi-] D; -śarerabhādi- A 16 sarve krimiyo vinaśyanti] A omits this sentence 17 -yitum] D; -yatum A • saṃsvedajā] D; -jāte A • upapādukā] D; upādukā A 18 prabhavanti] D; bhavanti A 19 noddhriyate] corr.; dedhriyate A, nodhriyate D • vividha-] D; vividhā A 20 noddhriyate] D; nodhriyate A • kșemasubhikṣāni] D; kṣemasuṣpāni A 22 samvidhāsyanti] ApcD; simvidhāsyanti Aac <A36r>
} 
one in the western direction. A five-headed one in the southern direction. A three-headed one in the northern direction. A nine-headed Nāga should be placed in the middle of the mandala. Four ladles ${ }^{25}$ with frankincense should be placed [in the four directions] and a fifth in the middle of the mandala. Mixed parched grain and mustard seeds should be enchanted twenty-one times and thrown in the four directions. This dhärañi should be written down and mounted at the top of a flagstaff ${ }^{26}$ in the four corners of the mandala. These should be placed in the middle of the field. These should be placed in the middle of the garden. Immediately after these have been placed, the great mountain slope sealing of the boundary is completely established in the four directions.

[1.11] "The great sealing of the boundary is present until the stake is drawn out. All crops, all flowers and fruits will be well protected. Furthermore, not even a single leaf will wither. How much less the ends of branches will become dry. All kinds of pests, wild animals and birds will be bound in the beak. They cannot cause destruction. Even if perished they ${ }^{27}$ gain vital power again. They reach vigour, growth and power again. The [contents of the] bowl should be sprinkled all around in the four directions in the fields and gardens. ${ }^{28}$ All pests will be destroyed. Snakes, mice, mongooses, porcupines, ${ }^{29}$ goats, ${ }^{30}$ frogs, ${ }^{31}$ stinging insects, mosquitos, locusts and so on, flocks of birds will perish. All worms will be destroyed. Furthermore, flying insects and so on do not occur. They are never able to destroy. Until the stake is driven out all kinds of pests, produced from moist heat, self-produced and egg-born, arisen from rocks or flowers, do not prevail. ${ }^{32}$ Harm of various sorts caused by Nāgas will not be victorious again. Until the stake is drawn out there will be comfort and plenty, and all crops, flowers and fruits develop. They will be juicy and tender. All Nāgas will constantly provide protection, shelter and safeguard.

25 For kațacchu(ka) see Edgerton (1953: 164) (henceforth BHSD).

26 For references to mounting spells at the top of a flagstaff, see Hidas (2012: 25-26, 223-24).

27 I.e. crops, etc.

28 This is the first mention of a pesticide in the text. See the next section [1.12] for the second one and [1.19] as well.

29 This animal with "needle-like bristles" is more likely to be a crop-eating porcupine than a hedgehog, which feeds primarily on small animals.

30 MW 409 lists goat and lion for jațila, "hairy one."

31 Remarkably, frogs are not treated as animals enhancing precipitation in this text.

32 For this stock list: cf. e.g. Kriyāsamgraha 6: yāvantạ̣ sarvasattvāḥ sarvasaṃraheṇa saṃgṛhītā aṇḍajā vā jarāyujā vā saṃsvedajā vā aupapādukā vā rūpiṇo vā arūpiṇo vā saṇgino vā asaṇgino vā naiva saṇgino vā nāsaṇgino vā sarve te sattvā mayā mahāmudrāpade pratișṭhāpayitavyāḥ. See also Saṃvarodayatantra 2.1-5 and Sādhanamālā 6 among other texts. 
[1.12] sikatām ekaviṃśati vārān parijapya sarvasasyapuṣpaphalapatravṛkṣeșu okiratavyāḥ | sarvaprāṇakā patanti vinaśyanti | sarvaśambūkatrailāțakāśíviṣā śatapadā anyāś ca vividhāḥ prāṇakajātayo vinaśyanti | yāvat kīlakaṃ noddhriyate na bhavișyanti |

[1.13] caturṣu sthāneṣu kṣetrasya śāntikaṃ karma kartavyam | yavatilasarṣapataṇụulāni ghṛtāktāni juhuyāt mahāśāntir bhaviṣyati | antaśa tiryagyonigatānām api na śakyaṃ vināśayitum | iyaṃ dhāraṇī sakalopacāravidhinā likhitavyā | buddhaṃ ca bhagavantam agastyaṛ̦i vajradharaś ca likhya uccasthāne dhvajāgrāvaropitaṃ kartavyam | balipuṣpadhūpaṃ ca dātavyāḥ | khadirakīlakaṃ aștāñgulapramāṇaṃ sahasravārā śaraṇamūrdhni nikhantavyam | sarvavātaśītameghāśani stambhitā bhaviṣyati | sarvasasyapuṣpaphalapatravināśakāḥ prāṇakā vinaśyanti | daṃśamaśakapipīlikāpataṃgamakṣikāsphuramakṣikābhramarakṛmiṣ́ṇngalikāvātālika-ulūkamūṣikadīrghamukhīprabhṛtayaḥ prāṇakajātāḥ sarve vinaśyanti | na prabhavișyanti | sarve pralayā bhavișyanti | kākavāyasacațakacañcațikakapotasurika-ulūkakhañjanakaśukaśārikādayah sarve vinaśyanti |

2 okiratavyāḥ] D; ovirataḥvyāḥ A • sarva-] D; sarvai A •-prāṇakā] D; -ko A <D31r • patanti] D; payanti A • sarva-] D; sarvai A • śambūka-] conj. Balogh; traimbūka AD $\mathbf{3}$-padā] D; -vyadā A • -jātayo] D; -jātiyo A 4 noddhriyate na] conj.; noddhriyatāni AD 7 tiryagyonigatānām] D; -nāp A 8 sakalopacāra-] D; sakalāpalo- A $\langle\mathrm{A} 36 \mathrm{v}\rangle$ • likhitavyā] D; likhitvāḥ A • agastyaṛ̣i] ] em.; āgatyaṛ̦i AD 9 dhvajāgrāvaropitaṃ] ] D; dhvajāgre 'varopitaṃ A 11 sahasravārā] D; -vāro A • -mūrdhni] corr.; -mūrdhi A, -mūrthi D • sarva-] D; sarvai A 12 bhavișyati] <D31v> 13-14 -sphura-] D; -sphara- A • -kṛmiśrṇngalikā-] em.; -kṛklilika- A, -kṛ+liș̣ngalikā- D • -yaḥ] corr.; -yoḥ AD <A37r> 15 pralayā] D; parayā A 16 -ulūka-] D; -ulū- A • -khañjanaka-] D; -șañjanaka- A 
[1.12] "Having enchanted sand ${ }^{33}$ twenty-one times it should be scattered ${ }^{34}$ on all crops, flowers, fruits, leaves and trees. All pests fall down and perish. All snails, horse flies, venomous snakes, centipedes and other pests of various kinds will be destroyed. Until the stake is drawn out they will not appear.

[1.13] "A pacification rite should be performed at four places in the field. One should offer barley, sesame, mustard seed and rice grain anointed with ghee; there will be great peace. Furthermore, even animals are unable to cause harm. This dhäraṇi should be written down according to the complete offering manual. One should paint the glorious Buddha, Agastya ${ }^{35}$ Rși and Vajradhara and it should be mounted at the top of a flagstaff in an elevated place. ${ }^{36}$ Flowers and incense of offering ${ }^{37}$ should be given. A stake made of khadira wood measuring eight angulas should be [enchanted] a thousand times and driven into the ground on the top of a dwelling. ${ }^{38}$ All winds, cold spells, clouds and thunderbolts will be stopped. All pests destroying crops, flowers, fruits and leaves will perish. All stinging insects, mosquitos, ants, flying insects, bees, quivering bees, bumble bees, worms, ones with a sting, ${ }^{39}$ vātālikas ${ }^{40}$ owls, mice, long-mouthed ones $^{41}$ and so on and various sorts of pests perish. They will not appear. They will be destroyed. All crows, large birds, sparrows, cañcațikas, ${ }^{42}$ pigeons, surikas, ${ }^{43}$ owls, wagtails, ${ }^{44}$ parrots, mynas ${ }^{45}$ and so on perish.

33 For empowered sand, see Sanderson (2015: 7).

34 Cf. Pali okirati.

35 Agastya is the son of Varuna (and Mitra) and thus connected to waters. See Bolon (1991); Bühnemann (2017).

36 Compare uccasthāna [1.13] [3.15] [5.6] with śaraṇamūrdhan [1.13], bhavanasara, uccasara [2.27], uccaśarasi, ūrdhvasarasi [4.1] and uccaśarana [6.7]. The main point is likely to be the proximity to the sky. Cf. Amoghapāśakalparāja 26a vidyādhareṇa mūrddhaśarane gandhamaṇḍa[la]kam karttavyam, 28b gṛhe mūrddhaśaraṇam sthāpya, 61a mūrddhaśaraṇe mandalakam karttavyam; and 20a, 22b bhavanavare. See also Klein (2018: 248): "while in retreat on the highest point of the property he protects, the hailmaster (...).”

37 Cf. balipuṣpa in Mahāpratisarā [49].

38 Compare śaranamūrdhan with bhavanasara, uccasara [2.27], uccaśarasi, ūrdhvasarasi [4.1], uccaśaraṇa [6.7] and uccasthāna [1.13] [3.15] [5.6].

39 This is probably a corrupt part. Is śrngalika perhaps an alternative form for śrngin (horned animal) or perhaps related to śrgāla (jackal)?

40 It is unclear what kind of animal a vātālika is.

41 It is unclear what animal a dirghamukhi is. In the Tibetan version the list is quite different and contains altogether roughly thirty kinds of animals.

42 It is unclear what kind of bird a cañcațika is. Read cañcuțika?

43 It is unclear what kind of bird a surika is.

44 Motacilla maderaspatensis.

45 Common myna or Indian myna (Acridotheres tristis). 
[1.14] anena mantreṇa diśābandhakīlakaṃ parijapyam |

namo buddhasya | ili mili caṇḍo micili caṇḍa caṇ̣a caṇ̣e bandhaya svāhā |

[1.15] athāgastyamaharṣir bhagavato nātidūre niṣaṇṇa imāṃ dhāraṇị̣̄ śrutvā utthāyāsanād bhagavataḥ pādayor nipatya bhagavantam etad avocat | aham bhagavan sarvaprāṇakajātīnāṃ dușțapradușțānāṃ viṣadhāriṇāṃ sasyapuṣpaphalapatragaṇ̣amūlakavināśakānāṃ tụ̣ḍabandhaṃ kariṣyāmi nivārayiṣyāmi tarjayiṣyāmi | mahatā samantād yojanaṃ caturdiśaṃ sīmāṃ dāsyāmi | saṃrakṣayiṣyāmi | bhagavan paścime kāle paścime samaye sarvadușțaparamapradușțān nivārayișyāmi | mantrapadān tava pradāsyāmi | tad bhagavan sarvasattvānām arthāya hitāya sasyapușpaphalapatraparirakșaṇārtham |

[1.16] atha sa maharṣir bhagavataḥ purataḥ sthitvā imāṃ dhāranīm bhāṣate sma |

namo bhagavate śākyamunaye tathāgatāya | namo agastyāya maharṣaye | tadyathā | kṛmi | cūri | cameli | vara vara | he vila | bandhani nāśani | daha daha | sumuri | cari | sarvadușțabandhane tuṇdabandhani sarvasaraṇi | kṣa kṣa kṣa | maṇi | kṣariși vasari | phuli phuṭi phuṭi samariṭi | sarantu sarvapāpaprānajāḥ | kṣadhili svāhā |

[1.17] samanantarabhāṣitā agastinā maharṣiṇā bhagavataḥ purataḥ iyaṃ vidyā | atha te sarvadușțanāgā yakṣā rākṣasā adhomukhair nipatitāḥ | bhagavantam uccasvareṇākrandaṃ kurvate sma | nașțā vayaṃ bhagavann ṛ̣iśāpena śapitā dagdhā vayaṃ bhagavan ṛ̣iśāpāgninā saṃdagdhāḥ | na vayaṃ bhagavan bhūyo

1 parijapyam] D; paritajapyam A 2 micili] D; micile A • caṇḍe] D; caṇdai A • bandhaya] D; -ye A 3 athāgastya-] D; atha tathāgatasya $A \bullet$-maharșir] D; -mahārșa A 4 -āsanād] D; āsanā A • nipatya] D; -tye A $\langle$ D32r $>\quad 5$ bhagavan] $\langle\mathrm{A} 37 \mathrm{v}\rangle \quad \mathbf{9}$-parama-] corr.; -prama- A, -prasama- D • -duștān] D; -duștānāṃ A 10 bhagavan] A; bhagan D 12 bhagavataḥ] D; -ntaḥ A • purataḥ] $<$ A38r $>14$ namo agastyāya] D; anāstyāya A <D32v> 15 cameli] D; camari A • vara²] D; vare A • vila] D; vina A • bandhani] D; -ini A 16 sarvasaraṇi] D; sarvesaraṇi A 17 vasari] D; vasa A - phuli] D; phali A • sarvapāpa-] D; sarvapāya- A 19 purataḥ] D; om. A 20 -dușțanāgā] D; -duștāā nāgā A <A38v> • -mukhair] D; -mukhau A 21 -ākrandaṃ] A; -ākrandana D • kurvate] D; kurvati A • bhagavann] D; bhagavata A • ṛ̣iśāpena] D; ṛ̣iṇārșyaṇam A 22 bhagavan ${ }^{1}$ em.; bhavan AD • -dhāḥ | na] A; -dhāni D 
[1.14] "The stake for sealing the boundary should be enchanted by the following mantra:

“Veneration to the Buddha. Ili mili caṇdo micili caṇda caṇda caṇ̣e seal svāhā."

[1.15] Then Agastya, the Great R̦̣ii, sitting not too far from the Bhagavān, having heard this dhärañi, arose from his seat and falling at the feet of the Bhagavān addressed the Bhagavān, "O Bhagavān, I will make a beak-sealing for pests of all sorts, malevolent and hostile, poison-holders, destroyers of crops, flowers, fruits, leaves and the best roots; I will keep them off and threaten them. I will provide a great $^{46}$ boundary measuring a yojana ${ }^{47}$ all around in the four directions. I will provide protection. O Bhagavān, in the last time, in the last age, I will keep off all the malevolent and extremely hostile. I will give you the mantrapadas. 0 Bhagavān, that is for the advantage and benefit of all people, for the sake of protecting crops, flowers, fruits and leaves."

[1.16] Then the Great Ṛși uttered this dhāraṇi standing in front of the Bhagavān,

"Veneration to the glorious Śākyamuni Tathāgata, to Agastya, the Great Rṣi. Namely, krmi, cūri, cameli, O Best One, O Best One, he vila, O the One who Binds, $O$ the One who Destroys, burn, burn, sumuri, cari, $O$ the One who Binds all the Hostile, $O$ the One who Binds with the Beak, $O$ the One who Goes Everywhere, kșa kṣa kṣa, maṇi, kṣuriși, vasa, phali, phuți, phuți, samariți, let all harmful pests go away, kṣadhili svāhā.”

[1.17] Immediately after this spell had been uttered in front of the Bhagavān by Agastya, the Great R̦și, then all the hostile Nāgas, Yakṣas and Rākṣasas fell with their face downwards. They called the Bhagavān for help in a loud voice, "O Bhagavān, we are destroyed, we are cursed by the curse of the Rși, we are burnt, O Bhagavān, we are consumed by the fire of the curse of the R̦̣i. O Bhagavān, we

46 Cf. Amoghapāśakalparāja 6a: śramaṇabrāhmaṇebhyo mahatā amoghasiddhim pratilabhate.

47 A yojana equals a few miles, varying in different sources (see Fleet [1906]). 
jāmbudvīpe sattvān vihețhayāmaḥ | na ca bhagavan bhūyaḥ sasyapatrapuṣpaphalāni vināśayiṣyāmaḥ | sarvaprāṇaka iti nivārayiṣyāmaḥ |

[1.18] tad bhagavān uvāca | evaṃ bhujagādhipataye yuṣmābhị̣ karaṇiyam | anurakșadhvaṃ jambudvīpakā sarvasattvān sarvasasyapatrapuṣpaphalapalāśasukhasaṃvardhikā bhaviṣyāmaḥ |

[1.19] atha sa maharṣir upacāravidhiṃ vakṣyati | asya bhagavan vidyā maharṣihṛdayam udakabhājanām așțottaraśatavārān parijapya pūrvābhimukhaṃ sthitvā ṛ̣imaunayā caturdikșu prakșeptavyam |

ara sara śara pāśa saptaṛ̣ihṛdayakrodhāc ca mukhaṃ bandhaya prāṇavara ghumuru cale svāhā |

evaṃ sapta vārān parijaptavyam | sahaprayuktamātreṇa sarvadușțanāgās taptā bhavanti | sarvaprāṇakajātayaḥ yāvad dvipadacatuṣpadāḥ śāpataptā bhavanti | sarve apasaranti | na ca bhūyas tatra pradeśe sasyapị̄ā nātikramiṣyanti | sarvaprāṇakajātayo vinaśyanti | na ca bhūyaḥ puṣpaphalapatraṃ sasyāni vinaśyanti |

[1.20] atha bhagavāṃs tasya maharṣeh sādhukāram adāt | sādhu sādhu maharṣe evaṃ te karaṇiyaṃ yathā sarvasattvāḥ svārakṣitā bhaviṣyanti | sarvasasyapuṣpaphalāni svārakṣitāni bhaviṣyanti |

[1.21] atha vajrapāṇir mahāyakṣasenāpatir bhagavantam etad avocat | adhitișthatu bhagavan paścime kāle paścime samaye anurakșayiṣyāmi paripālayiṣyāmi |

1 jāmbudvīpe] em.; -dvīpī AD 2 sarvaprāṇaka] conj.; saprāṇaka AD $\mathbf{3}$ tad] D; ten A • bhujagādhipataye] D; bhujaṃādhipatiye A • karaniiyam] D; -ye A 4 anurakṣadhvaṃ] corr.; amuṃrakșadhvaṃ A, anurakșyadhvam D • sarvasattvān] $\langle$ D33r $><$ A39r $>\quad 5$-phalapalāśa-] conj.; -phalāsā- AD •-sukhasaṃvardhikā] D; -sukhaṃbharvardhikā A $\mathbf{6}$ vakșyati] D; vakṣati A 7 udakabhājanām] conj. Tib; udakābhyangaṇāṃ A, udakābhyunganāṃ D • parijapya] A; pavijapya D 8 caturdikșu] D; cakșudikșu A • prakșeptavyam] A; kṣeptavyam D 9 ara] A; atha D • sara] D; om. A • bandhaya] D; -ye A 10 cale] D; casa A 11 vārān] D; vāraṃ A • -duștanāgās] A; -duștā nāgās D 12 yāvad] D; yāva A <A39v> • -catuṣpadāḥ] D; -catupadāḥ A 13 sarve] A; sarva D • nātikramișyanti] D; nītikramișyanti A 14 sarva-] D; sarve A 16 bhagavāṃs] D; bhagavān A • maharșeh] D; maharșa A 17 maharșe] D; maharṣa A • sarvasattvāḥ] $\langle\mathrm{D} 33 \mathrm{v}\rangle$ • -rakșitā] corr.; -rakși AD 19 bhagavantam etad] D; bhagavantad A 20 adhitișțhatu] corr.; adhișțhatu A, adhișțhantu D • paścime $\left.{ }^{1}\right]<$ A40r $>$ 
shall not hurt the beings in Jambudvīpa again. O Bhagavān, we will not destroy crops, leaves, flowers and fruits again. We will ward off all pests.”

[1.18] Then the Bhagavān said, "O Serpent chiefs, you should act like this. Protect all beings on Jambudvipa, increase ${ }^{48}$ all crops, leaves, flowers and fruits with ease.”

[1.19] Then the Great R̦̣̦i taught the offering manual. "O Bhagavān, having recited the Great R̦și heart[-mantra] spell into a water-pot 108 times facing east, one should scatter [the water] in the four directions with R̦și-silence.

Ara sara śara pāsa because of the wrath of the heart[-mantra] of the Seven R̦̣is close the mouth, O Best Pest, ghumuru cale svāhā.

One should recite thus seven times. Upon reciting this all hostile Nāgas become inflamed. All pests, bipeds and quadrupeds become inflamed by the curse. They all retreat. There will be no harm for crops in that province again. All pests will perish. They will not destroy flowers, fruits, leaves and crops again.”

[1.20] Then the Bhagavān praised the Great R̦și, "Well done, well done, Great Rși, you should act thus so that all beings shall be well protected. All crops, flowers and fruits will be well protected."

[1.21] Then Vajrapāni, the great leader of the Yakșas, addressed the Bhagavān thus, "May the Bhagavān give his empowerment so that I shall provide protection and safeguard in the last time, in the last age."

48 Note the peculiar verb-form. Cf. utșjāmah in [3.2]. 
54 — Vajratuṇ̣̣asamayakalparāja

[1.22] sādhu sādhu vajrapāṇe parirakṣasva sarvasattvān iti |

[1.23] nāgahṛdayasya sasyapīịākalpaḥ samāptaḥ |

1 -rakṣasva] A; -rakṣyasva D • -sattvān] A; -sattvāv D 2 -kalpah] D; -kalpo A 
[1.22] "Well done, well done, O Vajrapāṇi, protect all beings."

[1.23] The Nāga heart[-mantra] ritual manual for crop damage has ended. 
[2.1] atha bhagavān mahatā parivāreṇa mahatā parṣatsaṃnipātena mahatā vyūhena mahatā ṛddhyanubhāvena mahatā prātihāryasaṃdarśanena vaiśravaṇasya mahārājasya bhavanam agacchat |

[2.2] atha bhagavān nātidūre vaiśravaṇasya bhavanam anuprāptaḥ | tatra pṛthivīpradeśe vișavakaṃ nāma-m-ațavīvaram | tatra vanavivaramadhye puṣkariṇy asti | tasyāḥ puṣkariṇyāś cānubhāvenāọakavatyāṃ rājadhānyāṃ kṣetrārāmavanopavanāni puṣpaphalāni saṃtarpitāny abhūvan | sarvajanastrīpuruṣadārakadārikāgo'śvavaḍavāmahișahastyușțragardabhādayaḥ sukhasaṃtarpitā abhūvan | sā ca puṣkirinịi dve yojanapramāṇaṃ vistārā vyāmacaturdiśo samantataḥ | sā ca puṣkiriṇī nānotpalapadmakumudapuṇụarīkasaṃchannā| nānāmatsyamakaratimingilaśiśumārabhramaranānājalajādirūpā|

[2.3] atha sā puṣkiriṇī anāvṛștipatite kāle sarvavanapușpaphalapatrapalāśāḥ śuṣkās tāni ca puṣpāṇi parimlānāni | tena matsyamakaratimingilaśiśumārabhramaranānājalajādirūpā udakaparihīnāḥ kiṃcinmātrāvaśiște udake daśadiśi dhāvanti saṃdhāvanti jīvitavirodhaṃ jīvitanāśaṃ ca ārtahṛdayā dhāvanti |

[2.4] atha bhagavān tatra puṣkiriṇīsare 'ntikam anuprāptaḥ | mahatā parivāreṇa tatrāpaśyad anekaśatasahasramatsyamakaraśiśumārabhramarā jīvitasaṃrakṣaṇāya daśadiśo dhāvanti karuṇaṃ prekṣyanti | bhagavāṃś ca samāśvāsya maitryālambanayācchațikāśabdaṃ dattavān | nāgān āhvayan dvir

2 mahatāī] A; mahatyā D • ṛddhy-] D; nāndy- A • -anubhāvena] D; -anumatena A • pratihārya-] D; pratihāryeṇa A - -darśanena] D; -darśantena A 3 bhavanam] corr.; bhagavannam A, bhavanas D $\mathbf{4}$ bhagavān] D; -vā A $\quad \mathbf{5}$ pṛthivīpradeśe] <A40v> • viṣavakaṃ nāma-m-] D; viṣavakā nāma-m- Aac, viṣavanākāma-m- Apc • -ațavīvaram] D; -ațavīraveram A 6 puṣkariṇy] A; puṣkiriṇy D • puṣkariṇyāś] A; -yā D • cānu-] A; -nu- D • -āḍakavatyāṃ] D; -āḍakatyāṃ A 7 puṣpaphalāni] $<$ D34r $>\bullet$-tarpitāny] D; -tarpittāny A $\mathbf{8}$ sarva-] D; sarve A • -dāraka-] ADpc; -dāra- Dac 9 ca puṣkiriṇī] ADpc; pucașkirinịi Dac 11 nānotpala-] D; nāmotpala- A • -saṃchannā] A; -saṃnāchạ̣ Dac, -saṃchannāḥ Dpc 12 -matsya-] D; -matsa- A <A41r> 13 sarva-] D; sarve A 14 parimlānāni] corr.; parilānāni A, parimlānina D 15 -jalajādirūpā] D; -jalādirūpā A 16 daśadiśi] ADpc; śadadiśi Dac • saṃdhāvanti] A; satvavanti D 17 ārtahṛdayā] conj.; ātuhṛ̣dayā A, āttuhṛdayī D $<\mathrm{D} 34 \mathrm{v}>$ • dhāvanti] ADpc; +++ Dac 18 tatra] ADpc; trata $\mathrm{D} a c$ • 'ntikam] D; tikam A • anuprāptaḥ] $<\mathrm{A} 41 \mathrm{v}\rangle$ - parivāreṇa] ApcD; rivāreṇa Aac 19 tatrāpaśyad] D; tatrād A • -bhramarā] A; -bhrama D 20 -saṃrakșaṇāya] corr.; -saṃlakṣaṇāpā A, -saṃrakṣyaṇāyā D 21 nāgān āhvayan] conj. Tib; anāgāhvanayaṃ A anāgāṃkanaya D 
[2.1] Then the Bhagavān went to the residence of Vaiśravana, ${ }^{49}$ the Great King, with a great retinue, a great assembly-gathering, a great host, an indication of great supernatural power, displaying great miracles.

[2.2] Then the Bhagavān reached the vicinity of the residence of Vaiśravaṇa. In that region there was a choicest forest called Vișavaka. ${ }^{50}$ There was a lotus lake in the middle of an opening of the forest. By the power of that lotus lake the fields, gardens, forests, groves, flowers and fruits in the capital of Adakavati ${ }^{51}$ became refreshed. All people, women, men, boys and girls, cattle, horses, mares, buffaloes, elephants, camels, donkeys and so on became delighted by comfort. That lotus lake had an expansion of two yojanas and [a depth of] a fathom ${ }^{52}$ all around in the four directions. That lotus lake was covered by various blue lotuses, lotuses, white water-lilies and white lotuses. It contained various fish, Makaras, ${ }^{53}$ Timingilas, ${ }^{54}$ alligators, bees and various other water-born beings.

[2.3] Then at the time of drought [at] the lotus lake, all forest flowers, fruits, leaves and foliage were dry, the flowers withered. The fish, Makaras, Timingilas, alligators, bees and various other water-born beings were deprived of water, and when only little water remained they fled in the ten directions, dashed, ran with pained hearts because their lives were obstructed and ruined.

[2.4] Then the Bhagavān reached the vicinity of that lotus lake with the great retinue and saw that many hundred thousand fish, Makaras, alligators and bees were fleeing in the ten directions to protect their lives, looking around in distress. Having comforted them with friendliness as a foundation the Bhagavān snapped his fingers. ${ }^{55} \mathrm{He}$ summoned the Nāgas even two and three [times]. Having

49 Vaiśravana, one of the Four Great Kings, is the lord of wealth in Buddhism, comparable to Kubera.

50 No mention of this forest is known to me elsewhere.

51 For a note on Aḍakavatī, see Hidas (2012: 205).

52 MW 1038: "the measure of the two extended arms (= 5 Aratnis), a fathom."

53 Makara is a kind of sea-monster.

54 For Timingila, see BHSD 253.

55 For acchațā see BHSD 7. 
api trir api | acchațikāṃ dattvā trisāhasramahāsāhasre lokadhātau śabdaṃ śrūyate | kenacit pūrvakena karmapratyayena teșām prāṇināṃ jīvitavirodham | tena mahānāgāḥ śabdaṃ na șrṇvanti | na ca bhagavantam anusmaranti |

[2.5] atha vairambhako nāma mārakāyiko yakṣasenāpatis trisāhasramahāsāhasre lokadhātau śabdam udīrayan ghoșam anuśrāvayan | mahānti bhayāni loke utpadyante saptame divase kalpoddāhah pravartate | nātra kiṃcid bhaved yat sarva na dahyate | bhavāgrād yāvad avīciparyantam iti |

\section{[2.6] atha te}

sarvadevanāgayakṣagandharvāsuragaruḍakiṃnaramahoragamanuṣyāmanuṣyā evaṃ śabdaṃ śrutvā hā hā kaștataraṃ mahākașțaṃ loke vināśakā utpannā iti |

[2.7] atha bhagavān jānāti ca karmapratyayād etad anubhūyate | api tu samanvāhartavyam iti | bhagavatā ūrṇākośād raśmiḥ pramukteti| te ca raśmayaḥ sarvanāgabhavanāni avabhāsayanti | avabhāsya punar eva nivartya ūrdhvata uṣnīṣe 'ntardhìyante sma |

[2.8] atha samantākāracchatracandrākaraparikaro nāgarājā sarvanāgān saṃnipatyaitad avocat | kiṃ bho nāgā raśmīnāṃ prādurbhāva iti | kim pratyayeti loke 'tpannaḥ |

[2.9] atha sāgaro nāgarājā pratyādhyāyan bhagavato 'nubhāvena raśmayo vinirmitā iti |

[2.10] atha sāgaro nāgarājā anyaiś ca maharddhikena nāgarājena yena bhagavāṃs tenopasaṃkrāmann upasaṃkramya bhagavatạ̣ pādayor

2 -pratyayena] conj. Tib; -ṣuvyāyena AD 3 bhagavantam] D; bhavantam A. Ms E begins here with -vantam <E47(17)r> 4 -kāyiko] AE; -yiko D <A42r> 4-5 yakșasenāpatis trisāhasra-] em.; yakșasenāpatimantrī sāhasra- A, yakșasenas trisāhasra- DE $\quad \mathbf{5}$-dhātau] DE; -dhātyai A • anuśrāvayan] AD; anuśrāvayananta E 6 utpadyante] $<$ D35r $>\bullet$ kalpoddāhaḥ] corr.; kalpodāhah ADE 7 nātra] D; nītra AE • bhaved] conj. Tib; bhayam ADE • dahyate] DE; dahate A 10 hā hā] DE; hā A • -kașțaṃ] DE; -kaște A 11 ca] <A42v> • anubhūyate] DETib; anuśrūyate A

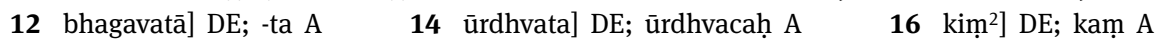
18 pratyādhyāyan] AE; -yet $\mathrm{D} \quad \bullet \quad$ bhagavato 'nubhāvena] AE; bhagavatānubhāvena $\mathrm{D}$ 18-19 atha...iti] This sentence is a marginal addendum in $\mathrm{D}<\mathrm{A} 43 \mathrm{r}>\mathbf{2 0}$ maharddhikena] DE; -ke A $\langle\mathrm{D} 35 \mathrm{v}\rangle$ • nāgarājena] AE; -rājai D • yena] D; om. AE 21 tenopasaṃkrāmann] DE; tenopakrāmann $\mathrm{A} \bullet$ bhagavataḥ] $\mathrm{AD}$; bhagavataṃ $\mathrm{E}$ 
snapped his fingers the sound could be heard in the Triple Thousand Great Thousand Universe. ${ }^{56}$ [But] the life of these beings was obstructed because of some previous deed. Therefore the great Nāgas did not hear this sound and did not recollect the Bhagavān.

[2.5] Then Vairambhaka, ${ }^{57}$ a Yakșa leader belonging to the retinue of Māra, uttered a voice and sounded a cry in the Triple Thousand Great Thousand Universe, "Great dangers have arisen in the world, there is the conflagration of the aeon in seven days. There is nothing here that will not burn completely from the highest point of the universe to Avici." ${ }^{58}$

[2.6] Then, having heard this voice, all the Devas, Nāgas, Yakșas, Gandharvas, Asuras, Garuḍas, Kimnaras, Mahoragas, humans and non-humans said, "Alas, alas, woe, woe, so bad that destroyers have arisen in the world."

[2.7] Then the Bhagavān knew that this is experienced because of a cause of action. Still one should have mercy on them. The Bhagavān released rays from the treasure of hair. These rays illuminated all the Nāga residences. Having illuminated them, they turned back and disappeared up in the topknot.

[2.8] Then the Nāga king Samantākāracchatracandrākaraparikara ${ }^{59}$ having summoned all Nāgas said, "O Nāgas, why is the appearance of rays? Is there a cause arisen in the world?"

[2.9] Then Sāgara, the Nāga king, ${ }^{60}$ having contemplated this [realized] that the rays were created by the power of the Bhagavān.

[2.10] Then Sāgara, the Nāga king, together with other Nāga kings of great supernatural power, approached the Bhagavān, went up to him and having

56 See Kloetzli (1983); Sadakata (1997).

57 Is this leader of the Yakșas connected to the Vairambha winds referred to in [5.6] and the Vairambha great ocean?

58 The Avici hot hell is the lowest point of the universe. See Sadakata (1997: 47-52).

59 Little is known about this Nāgarāja. Note the variations of this name throughout the text: Samantākāracchatracandrākaraparikara, Samantākāracchatrākaraparikaro, Samantākāracchatraparikara, Samantākāraparikaracchatra and Samantākāraparikaracchatrākara.

60 For Sāgara, a sea-god converted into a Nāgarāja, see Vogel (1926: 32, 191). 
nipatyaitad avocat | kiṃ bhagavan raśmipramuñcahetuh pravartate | kiṃ kāraṇam iti | raśmipramuñcanena sarvabhavanāny avabhāsya punar eva nivartāḥ |

[2.11] bhagavān evam āha | bho bhujagādhipate | bahūni prāṇiśatasahasrāṇi jīvitavirodhena virudhyante |

[2.12] atha sāgaro mahānāgarājā tatkṣaṇalavamuhūrtena puṣkiriṇiṃ varṣadhārābhiḥ pūrayitvā saṃtarpitam akārṣīt |

[2.13] atha tatra pṛthivīpradeśe mahān avakāśah prādurbhūtah | tatra pṛthivīpradeśe bhagavān niṣaṇnah | mahatparṣanmadhye pariṿ̛tah puraskṛto mahānāgaparṣatsaṃvṛta iti | yad utāśítināgasahasrāṇi mahānāgarājānāṃ saṃnipatitāni | sāgaranāgarājapramukhānām |

[2.14] atha samantākāracchatrākaraparikaro mahānāgarājā utthāyāsanād ekāṃsam uttarāsaṅgam kṛtvā dakṣiṇaṃ jānumaṇḍalaṃ pṛthivyāṃ pratișțhāpya yena bhagavāṃs tenopasaṃkramya bhagavataḥ pādau śirasābhivandya tripradakṣinịikṛtya bhagavantaṃ nānāpuṣpair gandhamālyavilepanābharaṇavastraih pūjayām āsa | pūjayitvā purato niṣaṇṇah |

[2.15] atha catvāro mahārājāno yena bhagavāṃs tenāñjaliṃ praṇamya bhagavantam etad avocat | atidāruṇāni bhagavan mahābhayāni loke utpannāni | yad utānāvṛ̦țidurbhikṣakāntārāḥ | anayā bhagavan vyasanayā sarvasattvā atrāṇā aśaraṇā abhūvan | bhagavāṃs tathārūpān mantrapadān bhāṣantu yena paścime kāle paścime samaye nānāvyasanasaṃnipāto lokaṃ samuttāraṇāya | ativṛștyanāvṛ̦țti-m-aśaniśîtoṣnavināśanārthāya | durbhikṣakāntārapraśamanārthāya | nivāraṇārthāya | paripālanārthāya | dhāranīimantrapadān bhāṣantu |

1-2 kim ${ }^{2}$...iti] A omits this sentence 2 -muñcanena] ADpcE; -muñcane Dac • avabhāsya] AD; avabhāsa E 3 nivartāḥ] DE; -varta A <E47(17)v> 4 evam] DE; om. A • bhujagādhipate] D; bhujaṃgādhipate AE 6 -lava-] AE; -la- D 7 -dhārābhị̣] DE; -dhārāhiṃ A • akārṣīt] DE; akārșitaḥ A <A43v> 8 -deśe] AE; -desye D • mahān avakāśaḥ] D; mahāvanakālaḥ AE • prādurbhūtaḥ] DE; prādur abhūt A 10 -vṛta] corr.; -vartta A, -vṛtta DE 11 saṃnipatitāni] DE; sampatitāni A 12 samantākāra-] AD; samantākā- E • utthāyāsanād] D; utthāsanād AE <D36r> 14 śirasābhivandya] <A44r> 16 -vilepanābharaṇa-] ApcDE; -vilepabharaṇa- Aac 18 mahābhayāni] DE; mehobhayāni A 20 aśaraṇā] DE; om. A • bhāṣantu] DE; -atu A 21 samuttāraṇāya] $<\mathrm{A} 44 \mathrm{~V}\rangle$ E continues later at [3.10] 22 -vināśanārthāya] A; -vināśanāśanārthāya D <D36v> 
bowed down at his feet said, "O Bhagavān, what is the reason for emitting rays? What is the cause? Having emitted them, they illuminated all residences, and then returned again.”

[2.11] The Bhagavān said, "Listen Serpent chief. Many hundred thousand beings are obstructed by life-obstruction.”

[2.12] Then Sāgara, the great Nāga king, filled the lotus lake with rain showers in a moment, an instant, a short time and refreshed [it].

[2.13] Then in that region a great opportunity occurred. The Bhagavān sat down in that region, in the middle of a great assembly he was surrounded and honoured, there was a great assembly of Nāgas, namely 80,000 great Nāga kings gathered, having Sāgara, the Nāga king, as their foremost.

[2.14] Then the great Nāga king Samantākāracchatrākaraparikara arose from his seat, arranged his outer robe on one shoulder, placed his right knee on the ground, approached the Bhagavān and, having bowed down at his feet, circumambulated him three times, and worshipped the Bhagavān with different flowers, fragrances, garlands, ointments, ornaments and cloths. Having worshipped him, he sat down in front of him.

[2.15] Then the Four Great Kings bowed to the Bhagavān with their hands put together and addressed him, "O Bhagavān, extremely frightening great dangers have arisen in the world. Namely, drought, famine, calamities. O Bhagavān, all beings have become defenceless and refugeless because of this misfortune. Let the Bhagavān utter such mantrapadas which deliver the world under destruction by various sorts of misfortune in the last time, in the last age, which eliminate excessive rain, drought, thunderbolts, cold spells and heatwaves, which alleviate, ward off and protect from famine and calamities. Utter the dhärañimantrapadas." 
[2.16] atha bhagavān vaiśravaṇaṃ mahārājaṃ dhṛtarāștraṃ mahārājaṃ virūụhakaṃ mahārājaṃ virūpākṣaṃ ca mahārājam etad avocat | asti mahārājan samantajvalitavidyun nāma saṃcodanīhṛdayadhāranīmantrapadā yena sahaśravaṇamātreṇa sarvanāgabhavanāni sarvanāgaśarīrāni jvalitāni bhaviṣyanti | sarvadușțanāgahṛdayāni kṣubhyanti | sarvanāgaśîrṣāṇi saptadhā sphuṭitāni bhaviṣyanti | akṣimūrdhāni sphuṭanti | khaṇḍakhaṇụāni viśīryante | tān mahārājāno g̣̣hṇata duṣțapraduṣṭānāṃ nāśanārthāya sarvasattvānāṃ paripālanārthāya |

[2.17] atha catvāro mahārājāno bhagavataḥ pādayor nipatyaivam āhuh | bhāṣatu bhagavan samantajvalitavidyun nāma saṃcodanīnāgahṛdayadhāraṇīmantrapadān |

[2.18] atha bhagavān nāgāvalokitena sarvatathāgatāvalokitena vyavalokya sarvanāgaparșan saṃnipātyaivam āha | śṛ̣vantu ime bhujagādhipataye dhāraṇimantrapadān |

tadyathā | oṃ vipulapravare | nāge mahānāge nāgahṛdayāvarte | jvala jvala sarvanāgahṛdayāni | kimi kimi | nāgakulavidhvaṃsani | hana hana sarvadușțanāgahṛdayāni | daha daha sarvanāgabhavanāni | paca paca pācaya pācaya sarvadușțanāgānām | ākrama ākrama sarvasamudrasāgaravimalavikrame mahānāgatejavare svāhā |

[2.19] sahabhāṣitamātrayā bhagavatā anayā nāgahṛdayadhāraṇīmantrapadayā atha te sarvanāgā tharatharāyamānā mlānaklinnadurgandhakāyāḥ saṃvịttāḥ | agnijvālā iva saṃdahyamānāḥ | paritaptam uccasvareṇa bhagavantam ākrandaṃ kurvanto bhagavantam evam āhuḥ | atidāruṇāni bhagavan

1 -śravaṇaṃ] D; -śramaṇaṃ A $\quad 2$ mahārājaṃ $\left.{ }^{1}\right]$ D; om. A $\quad 3$-vidyun] A; -vidyur D • -hṛdayadhāraṇīmantrapadā] D; -mantrapadā A 4 -śarīrāṇi] D; -śavirāṇi A $\mathbf{5}$ kṣubhyanti] D; śubhyanti A • -nāgaśīișāṇi] $\mathrm{AD} p c$; -nānāgaśīrșāṇi Dac <A45r> 7 nāśanārthāya] $\mathrm{D} p c$; kvāsanārthāya A, nānyaśanārthāya Dac 9 bhagavataḥ] $<\mathrm{D} 37 \mathrm{r}\rangle \quad 10$-atu] D; -antu A • bhagavan] A; -vān D • samanta-] D; saṃtānta- A • -vidyun] A; -vidyu D • nāma] D; nām A 12 -tathāgatāvalokitena] D; -tathātāvalokitena A 13 āha] $<\mathrm{A} 45 \mathrm{v}\rangle \bullet$ bhujagādhipataye] D; bhujaṃgādhipataye E 19 -vimalavikrame] A; -vimale vikrama- D 21 -nāgā] $\langle$ D37v $\rangle\langle$ A46r $>\bullet$ mlāna-] conj.; ālama- AD • -durgandhakāyāḥ] D; -dundhakāyāḥ A • saṃvṛttāḥ] D; om. A 22 iva] A; i D • saṃdahyamānāḥ] conj.; saṃdhayamānāḥ A, sanbūyamālāḥ D • paritaptam] conj.; paritārtam $\mathrm{AD} \bullet$ bhagavantam] A; bhavantam D 
[2.16] Then the Bhagavān addressed Vaiśramaṇa, the Great King, Dhṛtarāșțra, the Great King, Virūụhaka, the Great King, and Virūpākșa, the Great King, "O Great Kings, there are the impelling heart-dhäraṇi-mantrapadas called Completely Blazing Thunderbolt. Merely upon hearing, all residences and bodies of the Nāgas will be ablaze. It shakes the heart of all hostile Nāgas. The head of all Nāgas will split into seven. Their eyes and heads burst. They crumble to small pieces. O Great Kings, grasp them for the sake of destroying the hostile and malevolent and for the sake of protecting all beings."

[2.17] Then the Four Great Kings, falling at the feet of the Bhagavān, said, " $O$ Bhagavān, utter the impelling Nāga-heart-dhāraṇi-mantrapadas called Completely Blazing Thunderbolt.”

[2.18] Then the Bhagavān, having taken a look with a Nāga-look and a look of all Tathāgatas, addressed the whole Nāga assembly-gathering, "Let the Serpent chiefs listen to these dhârañi-mantrapadas.

"Namely, om O Extensive and Best One, O Nāgā, O Mahānāgā, O Nāga-heart-whirl, burn, burn the heart of all Nāgas, kimi, kimi, O Destroyer of Nāga families, kill, kill the heart of all hostile Nāgas, burn, burn all residences of the Nāgas, bake, bake, roast, roast all the hostile Nägas, attack, attack, $O$ the One with the Spotless Force of all Seas and Oceans, $O$ the One with the Choicest Power of the Great Nägas, svāhā."

[2.19] Immediately after this Nāga-heart-dhāraṇi-mantrapada had been uttered by the Bhagavān, then all Nāgas trembled, their bodies became weak, putrid and foul-smelling, and they were burning like a fire-flame. Being burnt ${ }^{61}$ they called the Bhagavān for help in a loud voice, and addressed him, "O Bhagavān, ex-

61 The Tibetan version gives "rolling on the ground" (gre ldog = àvartana/parivartana). 
mantrapadāni bhāṣitāni | sarvam asmākaṃ hṛdayāni vihețhyanti | vinașțā vayaṃ bhagavan dahyāma iti | adyaprabhṛti bhagavan sāmagrībhāvena bhagavatạ̣ puratạ̣ pratijñāṃ kariṣyāmaḥ | sarvapatrapuṣpaphalapalāśasasyāni paripālayiṣyāmaḥ | kālena kālaṃ varṣadhārā-m-utsṛjāmaḥ | sukhasaumanasyaṃ karișyāmaḥ | sarvasasyapuṣpaphalāni niṣpādayiṣyāmaḥ | tathāgatavacanāny anupālayiṣyāmah | satyapratijñena sthāpayiṣyāmaḥ | ekaputravat sarvasattvān anupālayiṣyāmaḥ | yatra yatraiva bhagavan pṛthivīpradeśe 'yaṃ vidyādhararājā pracariṣyati tatra tatra vayaṃ bhagavan sarvasāmagrībhāvena vihariṣyāmaḥ | smaraṇamātrayāpi bhagavan nitya vidyārājā vayaṃ sarve varṣadhārā-mutș̣jāmaḥ | smaraṇamātreṇāpi ativṛ̦țị̣ nivārayāmaḥ | na ca tathāgatavacanānujñātaṃ vilopayiṣyāmah | bhūyaś ca bhagavan śapathadhāraṇīmantrapadān dāsyāmaḥ |

[2.20] atha te sarvanāgarājāno bhagavataḥ pādayor nipatyaivam ūcuḥ |

tadyathā | oṃ cața cața vicața vicața śletha śletha śavari ciṭi svāhā |

durgandhā syur bhagavann asmābhị̣ | mā ca samyaksaṃbuddhā bhaveyuḥ | mā cāsmākaṃ nāgayonyā cyutiḥ syāt | yadi bhagavan na tena rātriṃdivena upacāravidhinā vidyādhareṇa kṛtena sarvajambudvīpe varṣadhārā-mutsrịāmahe sarvasattvānāṃ paripālanārtham tadā bhagavan vidyādhareṇāyaṃ śapathā dhāraṇimantrapadāḥ sapta vārān pūrvataramantram anusmārayitavyam | tataś caṇḍabījạ̣ aștotottaraśatam nāgasare juhuyāt | tadā bhagavann asmākaṃ sarvam agnijvālayā sakalabhavanāny ādīpyante | asmākaṃ śarīraṃ khaṇdakhaṇḍam višîryante | yāvad asthisaṃkalo 'vaśiș̣̦ạ̣ parimucyati | tadā vayaṃ bhagavan sarvam āśu âsu varṣadhārāḥ pramucyāmaḥ |

1 sarvam asmākaṃ hṛdayāni] conj. Szántó; sarvasasyākahṛdayāni A, sarvasasyābāhyadayāni D • vihețhyanti] em. Szántó; vipațhyanti $\mathrm{AD}$ • vayaṃ] D; vaye A 2 dahyāma] D; daddāma A • -prabhṛti] ADpc; bhṛti Dac 3 kariṣyāmaḥ] D; -yāmi A 4 paripālayiṣyāmaḥ] em.; -yāmi A, -yāmiḥ D 5 kariṣyāmaḥ] <A46v> 6 satya-] D; satyai A 7 'yaṃ] <D38r > 8-9 D includes sarvasāmagrībhāvena vihariṣyāmaḥ | smaraṇamātrayāpi bhagavan nitya vidyārājā vayaṃ as a marginal addendum 9 -mātrayāpi] A; -mātreṇayāpi D • nitya] D; aniya A 10 smaraṇa-] D; smara- A • nivārayāmaḥ] D; nirayāmaḥ A 11 -vacanānujñātaṃ] D; -vacanānajñātaṃ A • -yāmaḥ] D; -yāmi A • ca] <A47r> 12 śapatha-] em. Szántó; sa yathā AD • -padān dāsyāmaḥ] D; -padāsyāmaḥ A 14 vicața vicața] A; vicața vicața mā cāsmākaṃ nāgayonyā D 15 mā ca] conj. Szántó; sarva A, om. D 17 -dvīpe] D; -dīpe A 19 śapathā] D; sarvathā A <A47v $>\langle\mathrm{D} 38 \mathrm{v}\rangle$ 20 -bījạ̣] D; -bījā A 21 -bhavanāny] D; -bhagavanāny A $\bullet \quad$-dīpyante] D; -dīṣyante A 22 -khaṇḍam] D; -khaṇḍ̄a A 23 -mucyati] em. Szántó; -muṣyati AD 23-66,1 D includes āśu âśu varṣadhārā pramucyāmaḥ | yadi śīghraṃ varșadhān na mucyase tadā bhagavan sarve as a marginal addendum 23 âsu āśu] D; śighra śīghra A • pramucyāmaḥ] D; samucyāmaḥ A 
tremely dreadful mantrapadas have been uttered. All our hearts are tormented. $\mathrm{O}$ Bhagavān, we are ruined, we are burning. O Bhagavān, from today on we will make a vow with concord in the presence of the Bhagavān. We will protect all leaves, flowers, fruits, foliage and crops. We will send down rain showers duly at the proper time. We will provide comfort and gladness. We will ripen all crops, flowers and fruits. We will keep the orders of the Tathāgata. We will establish [ourselves] with a truth-vow. We will protect all beings like an only son. O Bhagavān, in whichever region this spell-holder king will circulate, there, O Bhagavān, we will reside with all concord. O Bhagavān, by the mere recollection of this spell-king we will all send down rain showers. By mere recollection we will keep off excessive rain. We will not break the authorization of the Tathāgata's words. Moreover, O Bhagavān, we will give the curse dhāraṇi-mantrapadas."

[2.20] Then all the Nāga kings, falling at the feet of the Bhagavān, said,

“Namely, om cața cața vicața vicața śletha śletha śavari ciṭi svāhā.

“O Bhagavān, let us be ill-smelling, let us not become perfectly awakened, let there not be a downfall from a Nāga-womb for us, ${ }^{62} \mathrm{O}$ Bhagavān, if we do not send down rain showers for the protection of all beings in the entire Jambudvipa after the spell-master has performed [rituals] according to the offering manual a night and a day. Then, O Bhagavān, the spell-master should call to mind this previous mantra and the curse dhäraṇi-mantrapadas seven times. Then he should offer caṇda ${ }^{63}$ seeds 108 times in the Nāga lake. Then, O Bhagavān, all our residences will blaze up by fire-flames. Our bodies crumble to small pieces until the skeleton remains. Then, O Bhagavān, we all release rain showers quickly and speedily. If we do not release rain showers rapidly, then, $\mathrm{O}$

62 In Mahādaṇdadhāraṇi-Sítavatī [7], fall (cyuti) from the Yakṣa-world is regarded as a punishment (Hidas 2017: 481). If the same meaning is intended here, it is unclear why the nothappening of a downfall is considered undesirable. Or does the text simply refer to birth from a Nāga-womb? Nāgayonyā is most likely an ablative here: cf. [2.28] nāgayonyāś cyutih.

63 MW 383: "a plant Andropogon aciculatus L.; Mucuna pruritus L.; Salvinia cucullata L.; white Dūrvā grass L.” 
yadi šīghraṃ varṣadhārā na mucyase tadā bhagavan sarve kālavaśagatā bhavet | saputrapautrā mariṣyāmahe |

[2.21] atha catvāro mahārājā vaiśravaṇapramukhā bhagavantam etad avocat | atidāruṇāni bhagavan nāgaśapathamantrapadāni bhāṣitāni nị̣karuṇāśapatha bhāṣitāni |

[2.22] bhagavān uvāca | paścime kāle paścime samaye mahārājānaḥ dușțâs caṇụā raudrāḥ sāhasikā vihị̣sakā nāgā bhaviṣyanti| tad anenāyaṃ śapathena bhītā bhavanti | uttrastā bhavanti | kālena kālaṃ varṣadhārā-m-utș̣janti | kālena kālaṃ sasyapuṣpaphalāni niṣpādayiṣyanti |

[2.23] atha vaiśravaṇo mahārājā bhagavantam etad avocat | brūhi bhagavann upacāravidhivistaram |

[2.24] atha bhagavān upacāravidhị̣ bhāṣate sma | anāvṛștiparigate kāle tena parvate araṇyāyatane vā vihāre vā utsahradataḍāge vā kūpe vā sare vā nāgabhavane vā trihastapramāṇamṛdgomayena maṇḍalaṃ kartavyam | madhyamaṇḍalake hastamātram khanitavyam | caturasraṃ hastapramāṇaṃ suślakṣṇasusaṃmṛțaṃ kartavyam | gandhodakena samantato okiratavyam | tatra khātamadhye catvāro nāgarājāḥ kartavyāḥ | kapilagomayamṛttikāsamanvitena navaśīrṣakaṃ phaṇi-m-ākāra ākuñcitaśarīram | sarvatra śirasi cintāmaṇiḥ kartavyāḥ | pūrvasyāṃ diśi sāgaro nāgarājā kartavyah | dakṣiṇasyāṃ diśi samantākāracchatraparikaro mahānāgarājaḥ kartavyaḥ | paścimasyāṃ diśi varuṇo nāgarājā kartavyaḥ | uttarasyāṃ diśi lambūlako nāgarājā kartavyaḥ | saptasaptaparivāāḥ kartavyāḥ | trisîirṣakaṃ vā dvisīișakaṃ vā pañcaśīrṣakaṃ vā nānāgandhena śarīrāṇi

1 śīghraṃ] D; śĩ A • -dhārān] A; -dhān D • -vaśagatā] D; -vaśatā A • bhavet] A; bhavemaḥ D 3 vaiśravaṇa-] D; vaiśramaṇa- $\mathrm{A} \bullet$ avocat] $<\mathrm{A} 48 \mathrm{r}>\mathbf{4}$-padāni] ADpc; -dāpani Dac • niḥkaruṇā-] corr.; tiḥkaruṇā- AD 8 uttrastā bhavanti] A omits this sentence • kālaṃ] $<$ D39r $>9$ sasya-] D; sa A 10 atha] A; thaa D 12 upacāravidhiṃ] <A48v> • anāvṛșți-] D; ativṛști- A 14 -bhavane] D; -bhuvane A • -mṛdgomayena] corr.; -mṛttikāmayana A, -mṛdgomayana D • maṇḍalaṃ] D; om. A 15 madhyamaṇḍalake] D; madhye maṇụalake A 16 suślakșṇa-] em. Szántó; sūmlakṣa- A; suplahle D • -susammmṛțam] em. Szántó; -sumlamṛșța A, -susnamṛțta D • okiratavyam] em.; 'karitavyam AD 18-19 A omits kapilāgomayamṛttikāsamanvitena navaśīișakaṃ phaṇim ākāra ākuñcitaśarīram | sarvatra śirasi cintāmaṇiḥ kartavyāḥ $\quad 19$ cintāmaṇị̣] Dpc; om. A, cintākāracchatramaṇiḥ Dac <D39v> 20 nāgarājā] D; mahānāgarājā A • -parikaro] <A49r> 21 -nāgarājaḥ] A; -nārājā D • nāgarājā] D; -rājo A 22 lambūlako] A; lambūluko D 
Bhagavān, all [of us] shall be subject to death. We will die with our children and grandchildren.”

[2.21] Then the Four Great Kings, led by Vaiśravaṇa, addressed the Bhagavān, "O Bhagavān, extremely frightening Nāga-curse mantrapadas have been uttered, merciless curses have been uttered."

[2.22] The Bhagavān said, "O Great Kings, Nāgas will be hostile, wrathful, fierce, ferocious and harmful in the last time, in the last age. By this curse they will become frightened. They will become scared. They will send down rain showers duly at the proper time. They will ripen all flowers and fruits duly at the proper time."

[2.23] Then Vaiśravaṇa, the Great King, addressed the Bhagavān, "O Bhagavān, teach the detailed offering manual."

[2.24] Then the Bhagavān taught the offering manual, "At the time of drought one should prepare a mandala with clay and cow dung measuring three hastas ${ }^{64}$ on a mountain, in a forest, at a monastery, a spring, a pool, a tank, a well, a lake, or the residence of the Nāgas. One should dig a hole measuring a hasta in the middle of the mandalaka. One should prepare a square [space] measuring a hasta, very smooth and well smeared. It should be sprinkled with perfumed water all around. Four Nāga kings should be prepared in the middle of the ditch. Full of brownish cow dung and clay a nine-headed [Nāga king should be prepared] with a hood and a coiled body. Wish-granting jewels should be made on the head everywhere [for all]. Sāgara, the Nāga king, should be prepared in the eastern direction. Samantākāracchatraparikara, the great Nāga king, should be prepared in the southern direction. Varuna, the Nāga king, ${ }^{65}$ should be prepared in the western direction. Lambūlaka, the Nāga king, ${ }^{66}$ should be prepared in the northern direction. Retinues of seven should be made for each.

64 MW 1294: "a measure of length from the elbow to the tip of the middle finger, = 24 Angulas or about 18 inches."

65 For Varuṇa, a sea-god converted into a Nāgarāja, see Vogel (1926: 32).

66 Little is known about this Nāgarāja. 
lepayitavyāni | candanaṃ raktacandanaṃ surabhicandanaṃ padmakạ̣ kun̉kumaṃ cūrṇayitvā vāsanair okiratavyam | puṣpamālyāni dātavyāni | lājāsarṣapāṇi tatra bhavanamadhye okiratavyāni | puṣpāvakīrṇaś caturṣu koṇeșu catvāro mahārājāḥ sthāpayitavyāḥ | caturșu dikṣu

sadhātukabuddhapratimā sadhātukacaityāni sthāpayitavyāni |

paț̣apatākālaṃkṛtaṃ kartavyam | pūjāś ca kartavyāḥ | agaruṃ candanaṃ turuṣkaṃ dhūpayata tagaraṃ naladaṃ kundurukaṃ medakaṃ lājāsarṣapaṃ sarjarasaṃ madhunā saha saṃyojyam | ekaviṃśati vārān mantreṇa parijapya nāgānāṃ dhūpo dātavyam | bahir maṇḍale samantena saktupadmena citrāpayitavyam | caturdvāraṃ vibhajya ekaikapārśve sapta sapta balipūrṇakāḥ sthāpayitavyāḥ | śuklabaliṃ nānārasavidhānaṃ yathāsaṃvidyamānaṃ sthāpayatā puṣpāvakīrṇaṃ kartavyam | nānābalinā racitavyam | phalāvakīrṇaṃ kartavyam | catvāraḥ pūrṇakumbhāḥ sthāpyāḥ | catvāro ghațapūrṇakā bali sthātavyāḥ | catvāri dhūpakațacchukāni gugguludhūpaṃ dhūpayatā | așțau dīpā jvālayitavyāḥ | vidyādhareṇa pūrvadvāre āhuti kuryāt | karavīrakāșțhaṃ sarṣapaṃ saindhavalavaṇamiśram așțottaraśatam juhuyāt | pūrṇa-maștottaraśate āhutīnāṃ sarve nāgā varṣadhārā-m-utsṛjanti | sarve jambudvīpe samantataś caturdiśaṃ varșadhārā-m-utș̣janti | sarve utsukyam āpadyante | sarve nāgā harșayanti |

eșa prathamo vidhị̣|

[2.25] sarṣapakațutailaṃ madhukaravīrapuṣpanāgapuṣpacūrṇagulikāḥ kartavyāḥ | tato gulikā nāgasare prakṣeptavyāḥ | așțaśatamantrajaptena

1 lepayitavyāni] D; sepayitavyāni A 2 vāsanair] em. Balogh; vāsener A, vāsyana D, om. Tib • okiratavyam] corr.; tokavyam A, okitavyam D 3 caturșu] <A49v> $\mathbf{6}$ paț̣a-] A; patu- D • kartavyāḥ] D; -vya A <D40r> 7 dhūpayata] A; -atāṃ D • naladaṃ] D; nadaṃ A 8 sarja-] D; sajja- A • saṃyojyam] D; saṃrokșya A • mantreṇa] D; mantraị̣ A 9 saktupadmena] D; sankupadmena A 10 citrāpayitavyam] ADpc; yitavyam Dac • balipūrṇakāḥ] <A50r> 12 -yatā] D; -yitā A • -kīrṇaṃ] A; -kīrnāa D • -balinā] conj.; -balinānā AD 13 catvāraḥ] D; -oḥ A • -kumbhāḥ] D; -kumbhaṃ A 14 -kațacchukāni] ADpc; -țakacchukāni Dac • gugguludhūpaṃ] D; gugulu- A 15 karavīra-] D; kanavira- A 16 juhuyāt] <D40v> 17 utsțjanti] <A50v $>\bullet$-dvīpe] D; -dīpya A 20 eșa] D; eșa tha A 22 kartavyāḥ] D; -vyā A 
They should be three-, two- or five-headed and their bodies should be smeared with various fragrances. Having ground sandal, red sandal, fragrant sandal, padmaka wood ${ }^{67}$ and saffron, it should be scattered along with fumigation. ${ }^{68}$ Flower garlands should be offered. Parched grain and mustard seeds should be scattered there in the middle of the [Nāga] residence. Having scattered flowers, the Four Great Kings should be placed in the four corners. Buddha images with relics, and caityas with relics should be placed in the four directions. Decorations should be made with ribbons and banners. Worship should be performed. One should perfume agaru, ${ }^{69}$ sandal and olibanum, and combine tagara, nalada, ${ }^{70}$ kunduruka, ${ }^{71}$ liquor, parched grain, mustard seed and sarja-resin ${ }^{72}$ with honey. It should be enchanted with the mantra twenty-one times and incense should be offered for the Nāgas. Decorations should be prepared with lotuses made of barley grits all around outside the mandala. Distributing four gates, seven [jars] filled with offerings should be placed on each side. Having placed a white offering of what is obtainable with an arrangement of various juices, flowers should be scattered. Various offerings should be arranged. Fruits should be scattered. Four filled jars should be placed. Four pots filled with offerings should be placed. Four ladles with frankincense and bdellium incense should be burnt. Eight lamps should be lit. The spell-master should perform oblations at the eastern gate. One should offer oleander wood, mustard seed, mixed with marine salt 108 times. After the 108 fire oblations have been completed, all Nāgas send down rain showers. They all send down rain showers in Jambudvippa, all around in the four directions. All of them become zealous. All Nāgas rejoice.

"This is the first manual.

[2.25] "Pills ${ }^{73}$ should be made of pungent mustard seed oil, honey, oleanderflower, nāgapuṣpa ${ }^{74}$ and powder. Then the pills should be thrown into the Nāga

67 MW 585: "Cerasus Puddum."

68 Vāsanair may also refer to residences or clothes.

69 MW 4: "Agallochum or Amyris Agallocha."

70 MW 530: "Nardostachys Jatamansi or Indian spikenard (...) the root of Andropogon Muricatus; the blossom of Hibiscus Rosa Sinensis L.; the honey or nectar of a flower L."

71 Note that both turuṣka and kunduruka are given as olibanum or frankincense in MW 451 and 291.

72 MW 1184: "Vatica Robusta."

73 For the preparation of pills of various substances by a Tibetan hailmaster, see Klein (2018: 243-46).

74 MW 533: "Mesua Roxburghii, Rottlera Tinctoria, and Michelia Champaka L.” 
sahaprakṣiptamātreṇa sarvanāgā hṛ̣yanti | mahāvarṣadhārā-m-utș̣janti | yadi sadyo na varșati teșāṃ nāgānāṃ śarīrāṇi viśīryante | śīrșarogā bhavanti duḥkhāni prādurbhavanti |

eșa dvitīyo vidhị̣ |

[2.26] āhutibhasmaṃ gṛhītvā kāñjikenāloḍya șaștivārān mantreṇa parijapayitavyam | bhavanamadhye prakṣeptavyam | sahakṣiptamātreṇa sarvanāgā vihvalīkṛtā bhavanti | tato varșadhārā-m-utsṛjanti | yadi sadyo na varṣati teșāṃ sarveșāṃ nāgānāṃ śarīrāṇi citrakuṣṭhī bhavanti|

eșa tṛtīyo vidhiḥ |

[2.27] padmakam arkanīlotpalaṃ haritālaṃ miśratāmracūrṇasarṣapaindrahastaṃ palāśaṃ ca guḍarasena saha bhāvayitvā guḍikāṃ kārayet prājñaḥ | aśîtivārān mantreṇa parijapya badarapramāṇāḥ gulikāḥ kartavyāḥ | nāgabhavane sapta guḍikāḥ prakṣeptavyāḥ | anāvṛ̣țikāle sapta rātridivamadhye 'vacchinna varșayanti | yadi sadyo na varșayati tato nāgabhavane sarvam ucchuṣyanti | sarvanāgabhavananivāsino bhagnā bhavanti | ekaguḍikā bhavanasare dhvajāgrāvaropayitavyā | nīlapatākā bandhayitavyāḥ | atha vā

1 saha-] D; sahasra- A 2 sadyo] D; sadya A • varṣati] -ati] A; -anti D • śīrṣarogā] D; śīrarogā A • bhavanti] <A51r> 4 eșa] D; evaṃ A $\mathbf{5}$-nāloḍya] D; -nīlāḍya A $\mathbf{6}$ prakṣeptavyam] corr.; prakșiptavyam A, prakșipitavyam D 7 sarvanāgā] $<$ D41r $>$ • bhavanti] ADpc; vabhanti Dac 8 citrakușțhi] D; ciṇitrekuṇțhi Aac, citrekuṇțhi Apc 10 arka-] D; om. ATib • miśra-] A; miśraṃ D 10-11 -sarṣapa-] A; -sahasarșapa- D 11 -indrahastaṃ] D; indrajavaṃ A • palāśaṃ] D; elosam A • guḍikāṃ] <A51v> 12 badara-] D; bațeri- A • -pramāṇāḥ] D; -pramāṇaṃ A • kartavyāḥ] D; -vyā A 13 -diva-] D; -divasa- A • -madhye] A; -manya D 14-16 A omits yadi sadyo na varșayati tato nāgabhavane sarvam ucchuṣyanti | sarvanāgabhavananivāsino bhagnā bhavanti | ekaguḍikā bhavanasare dhvajāgrāvaropayitavyāḥ | nīlapatākā bandhayitavyāh | 14-15 sarvam ucchuṣyanti] ] D; om. A 15 -nivāsino] em.; om. A, -nivāsito D 16-72,1 atha... sthāpayitavyam] D omits this sentence 
lake. After the mantra has been recited 108 times, and merely upon throwing [pills] into the lake, all Nāgas rejoice. They send forth great rain showers. If it does not rain on the same day, ${ }^{75}$ the bodies of those Nāgas will be destroyed. They will have head diseases, there will be suffering for them.

"This is the second manual.

[2.26] "Having taken ashes from oblations, it should be mixed in rice gruel enchanted sixty times with the mantra. It should be thrown into the middle of the [Nāga] residence. Merely upon throwing all Nāgas become agitated. Then they send down rain showers. If it does not rain on the same day, the bodies of all those Nāgas will have spotted leprosy. ${ }^{76}$

"This is the third manual.

[2.27] "The wise one should prepare a pill having mixed padmaka, arka, ${ }^{77}$ blue lotus, orpiment, mixed copper powder, mustard seed, indrahasta ${ }^{78}$ and palāśa ${ }^{79}$ with sugar juice. Having enchanted with the mantra eighty times, pills measuring a jujube fruit should be made. Seven pills should be thrown into the residence of the Nāgas. At the time of drought it rains for seven nights and days incessantly. If it does not rain on the same day, then the residence of the Nāgas will completely dry up. All residents of the Nāga residence will be shattered. A pill should be mounted on the top of a flagpole at the residence lake. Blue banners should be fixed. ${ }^{80}$ Furthermore, [pills at the] top of a flagpole should be

75 Or "immediately." The Tibetan version gives "at once" here and elsewhere in the text.

76 MW 396: "white or spotted leprosy."

77 MW 89: "Calotropis Gigantea (the larger leaves are used for sacrificial ceremonies)."

78 MW 167: "a kind of medicament L."

79 MW 610: "the blossom of the tree Butea Frondosa (...) the tree Butea Frondosa (...) Curcuma Zedoaria L.”

80 See section [3.16] for a blue thread. The Meghasūtra contains references to blue at many places (cf. Schmithausen [1997: 61]): "He who desires a mighty rain must perform this rite "the great-cloud-circle' in an open space, overspread by a blue canopy, shaded by a blue banner, on a clear spot of earth; (being) a prophet of the Law, seated on a blue seat, fasting according to the ashțânga, with well-washed limbs, clad in pure raiment, anointed with fragrant odour, wearing the three white stripes, he must recite it for a day and night continuously facing the east; he must place four full vessels, filled with pure blue water" and "a blue canopy and blue dress, blue banner and all the offering is to be made blue" (Bendall 1880: 303, 309). Note that an early Tibetan ritual manual from Dunhuang catalogued as IOL Tib J 401 contains references to the officiant's garments being blue (see van Schaik [forthcoming] also quoted in 5.2 of the introductory section of this volume). See also Nebesky-Wojkowitz (1956: 477). 
uccasare dhvajāgre sthāpayitavyam | aśanikāle aśaniṃ nāgā na śaktāḥ pātayitum | yathā suvarṇavarṇarūpam tasya nāgāḥ paśyanti | sarvabhayabhītā nāgāḥ saṃtișthanti | yathākāmas tāvad varṣati |

oṃ suvrate vajratuṇụe mili mili svāhā|

eșa mantra

tāțavakatpratikṛtim kṛtvā navaśīrṣakaṃ nāgam așțāngulipramāṇaṃ hingulakena śarīraṃ rañjayitavyam | patākāḥ kaṇṭhe bandhayitavyāḥ | caturasraṃ maṇḍalakaṃ kartavyam | puṣpāvakỉrṇaṃ ca kartavyam | nāgapratimā madhye kartavyā | yathāsaṃvidyamānā balir dātavyā | dāḍimalatayā ekavimiśativārān parijapya aștottaraśata vāraṃ vā sahasrajaptena vā dāḍimalatayā nāgapratimārūpakam unmārjayitavyam | yasya nāmnā kriyate sa nāga ākarșito bhavati | sa ca nāgo na bhūyaḥ svabhavane ramate | yadi śīghram varșadhārā-m-notș̣jati sadyo jīvitavināśo bhavișyati | sarṣapam ekaikaṃ parijapyāșțottarasahasraṃ pūrṇa-așțottarasahasreṇa tan nāgapratirūpaṃ prakramati | phaṇi karoti | tato dāḍimalatayā tarjayitavyam | pratișthati jihvāṃ darśayati | yāvad rātrau darśanaṃ dadāti | sarvanāgā vaśyā bhavanti | yat kathayati tat karoti | kṣirrasarṣapān așțottaraśatamantreṇa parijapitavyam | sarvatra sthānaṃ prokṣayati | sarvatra pratyānayanaḥ |

eșa caturtho vidhị̣ |

1 -āgre] corr.; -āgra A, om. D • aśanikāle] Dpc; aśatikāle A, anikāle Dac • nāgā] <D41v > 2 tasya] A; tasyā D 3 varṣati] A; -anti D $\mathbf{6}$ pratikṛtim] <A52r> • -māṇaṃ] D; -māṇā A 7 -lakena] D; -lake A • rañjayitavyam] D; vajrayitavyam A • bandhayitavyāḥ] D; -yā A 9 kartavyā] A; -yāḥ D • -vidyamānā] D; -vidyumānā A • dātavyā] A; -yāḥ D 10 dāḍimalatayā] D; tadāḍimalatayā A 11 vā] D; kā A • dāḍimalatayā] D; dāḍimalasateyā A • -rūpakam] corr.; -rūpaṃka A, -rūkampa D • unmārjayitavyam] corr.; unārjayitavyam A, umārjayitavyam D 12 yadi] <A52v> 13 -notș̣jati] D; -anti A $<$ D42r $>$ • bhavișyati] D; -anti A • sarșapam] D; varṣapam A 14 pūrṇa-așțottarasahasreṇa] corr.; pūrṇa-așțottarasahasreta A, om. D • tan] D; om. A 15 -rūpaṃ] A; -rūpakaṃ D • prakramati] D; prakamiti A • phaṇi] A; phaṇī D • dāọimalatayā] D; ḍimaletayā A • tarjayitavyam] em. Szántó; vajrayitavyam A, varjayitavyam D 17 -śatamantreṇa] D; -śamantre A 18 prokṣayati] conj. Szántó Tib; mokṣayati A, mokṣayanti D • sarvatra $^{2}$ ] D pc; sapatra sarvatra A, satrarva Dac 19 vidhiḥ] <A53r $>$ 
placed at the top of the lake. ${ }^{81}$ At the time of lightning the Nāgas are unable to hurl thunderbolts. The Nāgas see that as if golden-coloured. ${ }^{82}$ The Nāgas stand frightened by all fears and it rains as long as it is wished.

“Om O the One of Good Devotion, O Vajra Beak, mili mili svāhā.

"This is the mantra.

"Having made an image of dough, 83 the body of a nine-headed Nāga measuring eight angulas ${ }^{84}$ should be coloured by vermilion. Ribbons should be bound around the neck. A square mandalaka should be prepared. Flowers should be scattered. A Nāga image should be made in the middle. An offering of what is obtainable should be performed. A pomegranate branch ${ }^{85}$ should be enchanted twenty-one times or 108 times or reciting 1,000 times, the Nāga image-form should be purified with the pomegranate branch. In whose name it is done, that Nāga is attracted. That Nāga shall not be pleased in his own residence again. If he does not send forth rain showers quickly, his life will be destroyed on the same day. Having enchanted mustard seeds one by one 1,008 times, when the 1,008 times is completed, the Nāga image steps forward. It expands its hood. Then it should be threatened with a pomegranate branch. It rises up and shows its tongue. It appears all night long. All Nāgas become subdued. Whatever one says, it does that. Milk and mustard seeds should be enchanted with the mantra 108 times. If it is scattered everywhere, there is the restoration [of adverse effects] for all [Nāgas]. ${ }^{86}$

This is the fourth manual."

81 Compare bhavanasara, uccasara [2.27] with uccasthāna [1.13] [3.15] [5.6], śaraṇamūrdhan [1.13], uccaśarasi, ūrdhvasarasi [4.1] and uccaśaraṇa [6.7]. Would sara stand for śālā or śarana? The Tibetan translation gives "top of a house."

82 The Tibetan translation does not specify either what is golden-coloured. It is likely to be the vicinity of the flagpole. Note that in Suvarnaprabhāsottamasūtra 6.4.12,17,34 during the recitation of the text the whole universe will be adorned and lit up by golden light (Skjaervø 2004: 135, 139).

83 Ätavaka is unattested in dictionaries. The Tibetan version reflects "wheat/barley flour." Cf. Hindi $\bar{a} t \bar{a}$ "flour".

84 Note that anguli is also attested in MW 8.

85 Note that pomegranate is not a creeper, thus latā should refer to a softer branch.

86 I.e headache, etc. The Nāgas should not remain tormented or unhappy. 
[2.28] atha sāgaro mahānāgarājā anyaiś ca maharddhikair nāgarājair aśîtināgarājasahasrāṇi utthāyāsanād bhagavataḥ pādayor nipatyaivam āhuh | mahad bhagavan dāruṇāni mantrapadāni bhāṣitāni | atidāruṇāni karmasādhanāni | tad vayaṃ bhagavan na tu dhṛtyā bhaviṣyāmahe | kālena kālaṃ varșadhārā-m-utș̣jāmaḥ | na ca bhūyaḥ sattvān vihețhayāmahe | tad vayạ̣ bhagavan duștanāgānāṃ vihiṃsakānāṃ nāgānām arthāya asamayajñānīnāṃ pratisarikā mantrapadā bhāṣiṣyāmaḥ | tad bhagavann adhitișțhatu | bhujamgādhipate samayamantram adhișṭhiyāmi |

namo bhagavate śākyamunaye tathāgatāya | tadyathā | bhuje bhuje samantabhuje tattvabhuje pravarabhuje samantākārabhuje | turu turu svāhā | samayapālane svāhā | nāgasarasaṃcodane svāhā |

ayaṃ bhagavan mama nāgasamayamantraḥ | sarvadușțanāgānāṃ paścime kāle paścime samaye pratinivāraṇārthaṃ saṃcodanārthaṃ bhāṣitaḥ |

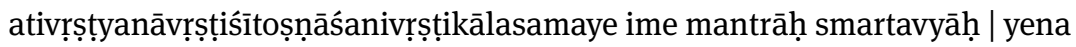
sarvanāgāḥ saṃcoditā bhaviṣyanti | tena vidyādhareṇa śucinā susnātena navacīvaraprāvṛtena nāgabhavanaṃ gantavyam | nāgabhavanasare gandhamaṇḍalakaṃ kartavyam | yathāsaṃvidyamānā bhagavatạ̣ saākyamuneḥ pratimāṃ sadhātukaṃ caityaṃ tatra maṇ̣alasyopari sthāpya gandhodakena snāpayitavyam | puṣpadhūpagandhena pūjayitavyam | caturdikṣu dhūpo dātavyam | sarvanāgāḥ saṃcodayitavyāḥ | taṃ ca snānodakaṃ aśîtivārān parijapya sarșapam tatraiva prakșipya tatra bhavanamadhye kṣeptavyam | sahakṣiptamātreṇa tasyodakasya nāgabhavanaṃ tatkṣaṇād guḍaguḍāyate | dhūmākāreṇa bhavanād utthāya mahad abhrapațalaṃ prādurbhavati |

1 -nāgarājā] A; -rājā D 3 mahad] D; maha A 4 -sādhanāni] D; -satāni A • na tu dhṛtyā] D; na tu tyā $\mathrm{A}<\mathrm{D} 42 \mathrm{v}>\quad 7$-jñānīnāṃ] A; -jñānānāṃ $\mathrm{D}$ • pratisarikā] conj.; praticāraṇā $\mathrm{AD} \quad \mathbf{8}$-atu] A; -antu D • bhujamgādhipate] A; bhujagāpate D <A53v $>$ • -yāmi] D; -yāma A 9 tathāgatāya] D; om. A - bhuje bhuje] D; bhuje A 10 tattvabhuje] D; om. A 12 bhagavan] ADpc; bhavagan Dac 14 -āśani-] D; -olani- A • yena] A; yenana D 15 bhavișyanti] $\langle$ D43r $>16$ nava-] D; naca- A <A54r> • gantavyam] D; gartavyam A 17 -maṇ̣alakaṃ] D; -maṇalaṃ A • -vidyamānā] ApcD; -vidyanānā Aac • bhagavataḥ] A; bhavataḥ D 18 sadhātukạ̣] corr.; sasadhātukaṃ A, sadhātukaṃ sadhātukaṃ D • tatra] D; tata A 19 dhūpo] D; dhūpi A 20 -nāgāḥ] D; -nāga A • -vyāḥ] D; -vyam A • snānodakaṃ] D; snātodakaṃ A 21 tatraiva] A; tastraiva D • kṣeptavyam] corr.; kṣapatavyam AD 22 tasyodakasya] D; tasyodake 'sya A • tatkṣaṇād] D; akuṇād A • guḍaguḍāyate] D; guguguḍāyate A 
[2.28] Then Sāgara, the great Nāga king, stood up from his seat along with other 80,000 Nāga kings of great supernatural power, and falling at the feet of the Bhagavān said, "O Bhagavān, greatly frightening mantrapadas have been uttered, extremely frightening ritual acts. ${ }^{87} \mathrm{O}$ Bhagavān, therefore we will not be unbending. We will send down rain showers duly at the proper time. We will not hurt beings again. $O$ Bhagavān, we will therefore utter the advancing ${ }^{88}$ mantrapadas for the sake of the hostile and harming Nāgas who do not know the vow. May the Bhagavān give his empowerment." "O serpent chief, I empower the vow mantra."

"Veneration to the glorious Śākyamuni Tathāgata. Namely, $O$ the One with Coils, $O$ the One with Coils, $O$ the One with Encompassing Coils, $O$ the One with True Coils, $O$ the One with the Best Coils, $O$ the One with Coils of Encompassing Form, turu turu svāhā. Svāhā to the One who Observes the Vow. Svāhā to the One who Impels the Nāga Lake.

"O Bhagavān, this is my Nāga vow mantra. It is uttered for the sake of warding off and impelling all hostile Nāgas in the last time, in the last age. These mantras should be called to mind at the time of too much rain, drought, cold spells, heatwaves and thunderbolt rain. By this all Nāgas will be impelled. The spellmaster, who is clean, well bathed and wears new robes $^{89}$ should go to the residence of the Nāgas. He should make a mandalaka of fragrant substances ${ }^{90}$ at the Nāga residence lake. Having placed as obtainable an image of the glorious Saakyamuni and a caitya with relics on top of the maṇdala there, these should be bathed with perfumed water. Worship should be made with flowers, incense and fragrances. Incense should be offered in the four directions. All Nāgas should be impelled. Having enchanted the bathing water eighty times, and having thrown mustard seeds into it, it should be thrown in the middle of the residence. Merely upon throwing it into the water, the residence of the Nāgas immediately rumbles.

87 I.e. the four ritual manuals.

88 Cf. [1.5] pratisarikā. The Tibetan version gives "turning-back, repelling."

89 Note the monastic reference.

90 Cf. Bühnemann (2003: 14 n. 3). 
gaganatale kṣeptavyam | sarvāśanayo na patanti | sarvavāyave baddhā bhavanti | sarvaśîtākālavāyavaḥ praśamati | arkakāșthaṃ ghṛtasarṣapaṃ karavīrapuṣpam așțottarasahasraṃ juhuyāt | nāgasare vā kūpe vā taḍāge vā puṣkiriṇyāṃ vā parvatamūrdhni vā kartavyam | sarvatra siddhyatīi | sahaprayuktamātreṇa mahatīṃ varșadhārā-m-utș̣janti | atiṿ̛șțikāle lājāsarṣapam așțottaraśatạ̣ parijapyākāśe kṣeptavyam ativṛștịm praśamayati | yadi bhagavan trirātreṇa vayaṃ varṣadhārā-m-notsṭjāmaḥ | tadā vayaṃ bhagavaṃś citrībhavemaḥ | atyantadurgandhakāyā bhavemaḥ | sarvabuddhadharmavisaṃvādakā bhavemaḥ | trailokyavisaṃvādakā mā cāsmākaṃ nāgayonyāś cyutị̣ syāt | anyāni ca bhagavan sarvakarmāṇi prayoktavyāni | sarvatropayujyante |

[2.29] atha bhagavān nāgarājānam samāśvāsya samaye pratișțhāpya vaiśramaṇo mahārājam upari 'dhyanuśāsya prakrāntaḥ |

[2.30] vaiśramaṇabhavanapraveśanāgasamaya nāma varṣaṇa-m-utsargạ̣ samāptaḥ|

1 gaganatale] $<\mathrm{A} 54 \mathrm{~V}\rangle$ • patanti] D; pātatti A • baddhā] A; ddhā D • -anti] D; -ati A 2 -ākālavāyavaḥ] D; -ākāyava A • arkakāșțhaṃ] <D43v $>$ • -puṣpaṃ] ADpc; -șpaṃ Dac 3 puṣkiriṇyāṃ] D; puṣkiṇyāṃ A 4 sahaprayukta-] D; sahasrayukta- A 6 kṣeptavyam] corr.; kṣapatavyam $\mathrm{AD} \quad$ • $\quad$-ati] A; -anti D $\quad 7$ citrïbhavemah] <A55r> 9 trai-] A; strai- D 10 sarvatropayujyante] D; sarvatopuyujyate A 11 -rājānam] D; -rājāsanam A • samāśvāsya] D; āśvāsya A • -ye] D; -yaṃ A 12 upari] A; nuparīm D <D44r> • prakrāntaḥ] em.; prakātā A, prakāntāḥ D 13 -bhavana-] D; -bhagavana- A • varșaṇa-m-utsargaḥ] em.; vavaiṇā-m-utș̣nga A, varșaṇā-m-utsargā D 
Arising from the residence in smoke form, a great cloud mass appears. Throwings should be made to the sky. No thunderbolts fall. All winds become bound. All cold spells and untimely winds calm down. One should offer arka wood, ghee, mustard seeds and oleander flowers 1,008 times. It should be performed at a Nāga lake, well, tank, lotus lake or on the top of a mountain. It will be successful everywhere. Merely upon employing, they send forth great rain showers. At the time of too much rain having enchanted parched grain and mustard seeds 108 times, these should be thrown to the sky. This will calm down excessive rain. O Bhagavān, if we do not send forth rain showers after three nights, then, O Bhagavān, we will have leprosy. We will have bodies of extremely bad smell. We will be adversary to the teaching of all Buddhas. Disappointing the Three Worlds, let there not be a downfall from a Nāga-womb for us. ${ }^{91} \mathrm{O}$ Bhagavān, [if] there are other acts to be employed, we will be to his assistance everywhere.”

[2.29] Then the Bhagavān, having encouraged the Nāga kings, and having established them in the vow, and having instructed Vaiśramaṇa the Great King, departed.

[2.30] The Sending forth of Rain called Entry into the Residence of Vaiśramana Nāga Vow has ended.

91 Cf. [2.20] for the difficulties with this sentence. The Tibetan version gives "let us depart from the Nāga birthplace." 
[3.1] athāto bhagavān brahmabhavane vijahāra | anekadevagaṇāh samāgatāḥ mahatā parṣadā bodhisattvagaṇạ̣̄ samāgatāḥ śakraś ca devānām indra brahmāviṣṇumaheśvarā nāgendrā maharddhikāḥ sarve samāgatāḥ | garuḍendro mahārājā suvarṇapakṣo vajratuṇ̣o mahātmā jvalitaśarīrạ̣ krodhano bhīmavikramạ̣ | nānāratnavicitraiś ca mauktisuvarṇarājitạ̣ | mukuṭapaț̣̄āvabaddhaśirā | suvarṇābharanavibhūṣitạ̣ | raudrarūpastabdhadṛștiś ca pannagendrakṛtāsanah | mahatā parivāreṇa sarve samāgatāḥ | vajrapāṇiś ca yakṣendro yakșakoțībhị̣ samāgatạ̣ | vidyādharaśatasahasraparivāraḥ | vajradharaś ca nānāmaṇiratnasamalaṃkṛtạ̣ | bhagavāṃś ca nānāraśmikoținniyutasahasrasamalaṃkṛtakāyạ̣ | suvarṇayūpam-iva dedīpyamānạ̣ | sūrya ivāvabhāsan dvātrimsśallakșaṇadharaḥ aśîtianuvyañjanaḥ | vyāmaprabhāsamalaṃkṛtaḥ | tathāgatakāyaṃ suviśuddham sunirmalaṃ prabhāsvaram |

[3.2] atha bhagavān mahāparṣatsaṃnipātaṃ viditvā svakāyān nānāraśmyavabhāsam utsṛjāmaḥ | yena raśmyavabhāsena samantād daśasu dikṣu vyavabhāsitāḥ |

[3.3] atha brahmāviṣnumaheśvarādayas tathāgataraśmị̣ vyavalokya jambudvīpam apaśyan | dușțanāgaị̣ šitavāyumeghāśani samutșrsțam | sarvapuṣpaphalasasyāni ye ca vṛkṣās tṛnagulmoṣadhivanaspatayạ̣ saṃdagdhā vināśitā niḥphalā iti jambudvīpaḥ kṛto 'bhūt |

[3.4] atha te sattvā mahatā duhkhhenāpagatā nānāpralāpaṃ pralapante sma |

1 bhagavān] D; bhagavat A • -gaṇāh] D; -nāgaḥ A 2 bodhisattvagaṇāḥ] <A55v> 6 -āvabaddhaśirā] D; -ābaddhaśirā A 7 -stabdhadṛștiś] D; -stambadṛștiś A • pannagendra-] D; pannajñendra- A 9 -samalaṃkṛtaḥ] $<$ A56r $>10 \mathrm{ca}$ ] $<$ D44v $>11$ ivāvabhāsan] D; ivābhavāsama gacchartti A • dvātriṃśallakșaṇa-] D; śallakșaṇa- A 14 mahā-] D; om. A • viditvā] D; vidirttā A 15 -raśmyavabhāsam] D; -raśmīvabhāsam A • -tād] D; -tā A 17 -yas] A; -yo D 18 dușṭanāgaiḥ] <A56v> 19 -oṣadhīvanaspatayaḥ] D; oṣadhīspatayeh A • saṃdagdhā] D; sandegdha A 20 iti] $<$ D45r $>21$-pralāpam] D; -palāya A • pralapante] D; palāyante A • sma] D; smai A 
[3.1] Now the Bhagavān was residing in the abode of Brahmā. Many Deva multitudes assembled with a great assembly, multitudes of Bodhisattvas assembled; Śakra, the Lord of the Devas, Brahmā, ${ }^{92}$ Viṣṇu and Maheśvara, Nāga Lords of great supernatural power, they all assembled. [There was] the Garuda Lord, the Great King, the one with golden wings, the one with a Vajra Beak, the magnanimous one, the one with a blazing body, the wrathful one, the one of frightful power. He was adorned with various wonderful gems, pearls and gold. His head was bound with a crown and a fillet. He was decorated with golden ornaments. He had a firmly fixed glance of dreadful character and a seat made by a serpent lord. All gathered with a great retinue. Vajrapāni, the Lord of the Yakșas, assembled with ten million Yakșas. Vajradhara, embellished with various jewels and gems, with a retinue of a hundred thousand Vidyādharas. ${ }^{93}$ The Bhagavān had a body ornamented with a net of ten million million thousand rays. He was blazing brightly like a golden pillar. He was brilliant like the Sun, displayed the thirty-two marks of beauty and the eighty minor marks of beauty. He was embellished with a radiance measuring a fathom. He had the body of a Tathāgata, extremely pure, extremely spotless and brilliant.

[3.2] Then the Bhagavān having perceived the great assembly-gathering, emitted $^{94}$ a splendour of a net of rays from his body. By the splendour of those rays the ten directions were completely illuminated.

[3.3] Then those beginning with Brahmā, Viṣnu and Maheśvara having seen that ray of the Tathāgata beheld Jambudvīpa. Hostile Nāgas have released cold spells, winds, clouds and thunderbolts. All flowers, fruits and crops, trees, grass, bush, herbs and large trees were burnt and destroyed and became fruitless - this is what happened in Jambudvipa.

[3.4] Then those beings, afflicted with great suffering, lamented various lamentations.

92 Note the variations between brahma - and the more standard brahma- in this compound in [3.1], [3.3], [3.5], [6.1], [6.2], [6.3] and [6.6].

93 Cf. Amoghapāśakalparāja 11b: hārītibhūtamātā ca tathā daśa vajrapāṇimahābalā | yathā vidyādharendrair mahāvajradharas tathā.

94 Note the peculiar verb-form. Cf. bhavișyāmaḥ in [1.18] 
[3.5] atha brahmāvișṇumaheśvarā bhagavataḥ pādayor nipatyaivam āhụ̣ | paśyatu bhagavan duștacaṇ̣anāgair jambudvīpe niḥpalāśạ̣ kṛtạ̣ | sarve vinaștạ̄h | sattvā mahādāruṇaduḥkham anubhūyante | bho nāgāḥ pratyakṣam idaṃ tbhayaś ca† tathāgatavikurvitādhișthānam | paśyate gambhīrabuddhajñānaṃ tathāgataprabhāvaṃ guṇaviśeșādhișțhānam |

[3.6] atha bhagavān garuḍavij̣̣mbhitavilokitạ̣ nāma samantajvālāmālāvikurvaṇaṃ nāma samādhị̣ samāpannaḥ | samanantarasamāpanne ca dvayo raśmayoḥ prajvālayanti sma | sahaprajvalitamātreṇa sarvanāgaśarīrāṇi prajvalitāny abhūvan |

[3.7] atha samantākāraparikaracchatro mahānāgarājā bhagavatah pādayor 10 nipatyaitad avocat | dahyāmi bhagavan dahyāmi sugata |

[3.8] atha bhagavāṃs tūṣnībhāvenādhivāsya ūrdhvaṃ vyavalokya samantād daśadiśo vyavalokya sarvatathāgatān namaskṛtya imāṃ mahāgaruḍavegavajrạ̣ nāma jvalitagaruḍatejohṛdayamaṇụalīr anusmṛtya |

oṃ vajravati garuḍavege hūṃ hūṃ janaya viș̣ja hūṃ phaṭ |

[3.9] atha te duștanāgā gaganatale taṃ pradeśam anuprāptāḥ | bhagavān idam mantraṃ bhāṣate sma | te duștanāgāḥ sarvapuṣpaphalasasyapatrapalāśā

1 -taḥ] D; -to A 2 -nāgair] D; -nājña A • niḥpalāśaḥ] corr.; nīhalāsa A, niḥphalāsa D 2-3 sarve vinaștāḥ] A omits this sentence $\quad 3$ sattvā] em.; sattvān $\mathrm{AD} \quad \mathbf{4}$ bhayaś ca] $\mathrm{AD}$; om. Tib 5 -prabhāvaṃ] <A57r> 6 -vijụmbhita-] em.; -vijebhita- A, -vihyambhita- D 8 dvayo] D; hṛdayo A $\bullet$ raśmayoḥ] D; raśmayocca A $\bullet$-yanti] D; -yiti A 9 saha-] D; sahasra- A 10 -parikaracchatro] D; -parikacchatro A $<$ D45v $>\bullet$ pādayor] A; pāda D 11 -yaitad] D; -yatad A • dahyāmi $\left.{ }^{1}\right]$ D; -āni $\mathrm{A} \bullet$ dahyāmi²] D; -āni A 12 bhagavāṃs] $\mathrm{AD} p c$; vāgavāṃs $\mathrm{Dac} 13$ daśadiśo] Ms B continues and ms $\mathrm{C}$ begins here with -diśo $<\mathrm{C} 1016 \mathrm{u}\rangle$ - -tathāgatān] $\mathrm{ABC}$; -tathāgan $\mathrm{D}<\mathrm{A} 57 \mathrm{v}\rangle$ 13-14 D includes imāṃ mahāgaruḍavegavajram nāma jvalitagaruḍatejohṛdayamaṇḍalīr anusmṛtya as a marginal addendum 13 mahā-] ACD; om. B • -vajraṃ] BCD; -vajra- A 14 nāma] BCD; nānāma A • -maṇụalīr] ACD; -maṇụalār B • -smṛtya] BCD; -smṛtye A 16 -tale] BCD; -le A • pradeśam] $\mathrm{BCD}$; praveśam A • bhagavān] BCD; bhavān A 17 -nāgāḥ] BCD; -nāḥ A • -sasya-] ABCDpc; -sasyaphala- Dac 
[3.5] Then Brahmā, Viṣnu and Maheśvara, falling at the feet of the Bhagavān addressed him, "Look, O Bhagavān, hostile and fierce Nāgas have created a lack of foliage in Jambudvipa. All have perished. Beings experience great and severe suffering. Listen, O Nāgas, there is the evident empowerment of the Tathāgata's miracles. Behold the deep knowledge of the Buddha, the power of the Tathāgata, the empowerment of special merit."

[3.6] Then the Bhagavān entered the concentration called the Expanded Garuda Glance, [also] called the Miracle of the Garland of Enveloping Flame. Immediately after he had entered the concentration, two rays shone forth. Merely upon shining forth, the bodies of all Nāgas flamed up.

[3.7] Then Samantākāraparikaracchatra, the great Nāga king, falling at the feet of the Bhagavān, addressed him, "We are burnt, O Bhagavān, we are burnt, $O$ Sugata."

[3.8] Then the Bhagavān, having consented to him by remaining silent, looked up, looked all around in the ten directions, venerated all the Tathāgatas and recollected this Blazing Garuḍa Thrust Heart Ruler [Mantra] called Great Garuḍa Speed Vajra.

"Oṃ O the One like a Vajra, O the One with Garuḍa Thrust, hūṃ hūm, produce, send forth, hüm phaț."

[3.9] Then those hostile Nāgas reached that province in the sky. The Bhagavān uttered this mantra. The hostile Nāgas, having placed all flowers, fruits, crops, 
bhagavataḥ purataḥ pratișțhāpya te ca nāgā mañkubhūtā bhagavataḥ puratạ̣ sthitāḥ tharatharāyamānāḥ |

[3.10] atha bhagavāṃs tathāgato garuḍajvālā nāma mahāhṛdayam abhāṣata |

namo bhagavate śākyamunaye tathāgatāya | oṃ jvala jvala | prajvala prajvala | hana hana | sarvanāgahṛdayadāraṇi | hana hana sarvanāgānāṃ balavīryaparākramam | daha daha sarvanāgaśarīrāṇi | paca paca sarvanāgamarmāṇi | garuḍapakṣanipātena pataya pātaya sarvanāgabhavanāni | oṃ matha matha mahācintāmaṇimaulidhara mahāgaruḍaveśadhara vicitrābharaṇavibhūṣitakāya sarvanāgānāṃ bhayaṃkara | smara smara bho garuḍendra | bhagavatah śākyamuner vacanam anupālaya | tarjaya nāgānāṃ bhakșaya sarvaduștān | pramathaya vāyuvegajavān | sphoțaya mūrdhānam | śoṣaya vidyujjvālān hūṃ hūṃ phaț | pramatha pramatha sarvavātāśanimeghān | nāśaya nāśaya sarvanāgabalān | prahara prahara vajratuṇụena | ākaḍḍhaya dușțanāgān | garja garja mahāgaruḍavegena hūṃ hūṃ phaṭ | śītavalāhākān stambhaya stambhaya śītavāyumeghān sarvanāgavidāraṇi hūṃ hūṃ phaṭ | tị̣i tiṭi hūṃ phaț | jale bhadanta sarvāśaniṃ tathāgatādhișțhānena hūṃ hūṃ phaṭ | oṃ amṛte amṛtaṃ bhavati sarvaśîtavāyumeghāśanir hūṃ hūṃ phaț | mātikrama bho garuḍādhipate | muñcāhi yakṣavāyūn garuḍakrodhamahāvega bandhaya vāyuvalāhakān | țịi țịti tịṭi 5 hūṃ phaț | bhakṣaya vātāśaniṃ nāśaya ciṭi ciṭi hūṃ hūṃ phaṭ phaṭ svāhā | pālaya bho garuḍendra hasa hasa hūṃ hūṃ phaṭ svāhā |

1 nāgā] em.; nāgān $\mathrm{ABCD}$ • mańkubhūtā] $\mathrm{BCD}$; om. A • bhagavataḥ²] $\mathrm{BCD}$; -vantaḥ $\mathrm{A}$ 3 bhagavāṃs] BCD; bhagavān A • -hṛdayam] CD; -hṛdayem AB 4 namo] ACD; oṃ namo B • śākyamunaye] $<\mathrm{A} 58 \mathrm{r}>\bullet$ jvala jvala] $\mathrm{ABD}$; jvala jva $\mathrm{C}<\mathrm{B} 27 \mathrm{r}>\quad \mathbf{5}$ sarvanāgahṛdayadāraṇi] $\mathrm{ACD}$; -dhāraṇī Bac, -dāraṇī Bpc <D46r $>$ hana hana²] BCD; hara hara A 7 pataya pātaya] C; patarya pātaiye A, pathaya pāthaya B, patayāpātaya D 9 -vibhūṣitakāya] $\mathrm{BCDpc}$; -vibhūṣitakāye A, -vibhūtakāya Dac 10 bhagavataḥ] BCD; bhagavah A • -pālaya] BCD; -pālaye A. Ms E continues here with -ye $<$ E54(13)r $>$ • tarjaya] $\mathrm{BCD}$; tarjaye AE 11 bhakșaya] $\mathrm{BCD}$; bhakșaye AE • pramathaya] $\mathrm{BCD}$; pramathaye $\mathrm{AE}<\mathrm{A} 58 \mathrm{v}\rangle$ • sphoțaya] $\mathrm{BCD}$; sphațaya AE 12 śoșaya] $\mathrm{BCD}$; śoṣaye $\mathrm{AE} \bullet$ vidyujjvālān] $\mathrm{BCD}$; vidyujvālānā $\mathrm{A}$, vidyujvānām $\mathrm{E} \bullet$-vātāśani-] $\mathrm{BCDE}$; -vāśamnnirA 13 -balān] ABC; -varān D, -bārān E • vajratuṇ̣ena] $<C 1015 d>15$ stambhaya stambhaya] $\mathrm{ABD}$; stambhaya staya $\mathrm{CE} \bullet$-vidāraṇi] $\mathrm{D}$; -vihāriṇi $\mathrm{A}$, -vidāraṇe $\mathrm{B}$, -vihāraṇi $\mathrm{C}$, vidāriṇī $\mathrm{E} \bullet$ tiṭi] $<$ D46v $>16$ jale] ACDE; ja+ B • bhadanta] ACDE; bhavantu B • sarvāśanimị] ACpcDE; sarvāśanāṃ B, sarvānī Cac 17 oṃ amṛte] ACD; ++++ B <B27v> • amṛtaṃ] BD; amṛta ACE • bhavati] BDE; bhavanti A, ++ti C 18 bho garuḍādhipate] BCE; mahāgaḍādhipate Aac, mahāgaruḍādhipate $\mathrm{A} p c \mathrm{D}<\mathrm{A} 59 \mathrm{r}>\bullet$ bandhaya] $\mathrm{ACD}$; bandha $\mathrm{B}$, bandhaye E 19 -valāhakān] BCDE; -valākān A • țịtỉ 3 A; ți BCDE • bhakșaya] BD; bhakșaye ACE 20 pālaya bho] BCD; yālaye ho A, pālaye bho $\mathrm{E} \bullet$ hasa hasa] BCDE; hara hara A 
leaves and foliage in front of the Bhagavān, ${ }^{95}$ stood shaking and trembling in front of the Bhagavān.

[3.10] Then the Bhagavān, the Tathāgata, uttered the great heart called Garuḍa Flame,

"Veneration to the glorious Śākyamuni, the Tathāgata. Om shine, shine, blaze, blaze, kill, kill, $O$ the One who Splits the Heart of all Nāgas, destroy, destroy the power, valour and strength of all Nāgas. Burn, burn the body of all Nāgas. Roast, roast the vitals of all Nāgas. Destroy, destroy all Nāga residences by the beat of Garuda wings. Om whirl, whirl, $O$ the One who Wears a Great Wish-granting Jewel on the Top of the Head. O the One who Wears Great Garuda Clothes, $O$ the One with a Body Decorated with Various Ornaments. $O$ the One who Causes Fear for all Nägas. Remember, remember, listen, O Garuda Lord, keep the words of the glorious Sākyamuni. Threaten the Nāgas, devour all the hostile. Destroy the thrust and speed of winds. Split the heads. Extinguish the flame of thunderbolts, hūm hūm phat. Destroy, destroy all winds, thunderbolts and clouds. Remove, remove all the power of Nāgas. Strike, strike with the Vajra Beak. Drag ${ }^{96}$ the hostile Nāgas, roar, roar with great Garuḍa thrust hūm hüm phaț. Stop, stop cold spells and clouds, cold spells, winds and clouds, $O$ the One who Splits all Nāgas, hūm hūm phaț. Tiți tiți hüm phat burn ${ }^{97} \mathrm{O}$ Venerable One all thunderbolts by the empowerment of the Tathāgatas hūm hūm phaț. Om O Immortality, let all cold spells, winds, clouds and thunderbolts become ${ }^{98}$ the nectar of immortality, hūm hūm phaț. Do not neglect [the vow], O Garuda Lord, release Yakșa winds, O the One with the Great Thrust of Garuḍa Wrath, bind the winds and clouds. Tiți tiți tiți tiți tiți tiți tiți tiți hūm phaț. Devour winds and thunderbolts, destroy, ciți ciți hūm hūm phaț phat svāhā. Guard, O Garuda Lord, laugh laugh, hūm hūm phat svāhā. Remember remember, $O$ the

95 It is unclear what flowers, fruits etc. are referred to here. Cf. [3.15].

96 See BHSD 86: for ākațtati/ākaḍ̣hana. Cf. e.g. Amoghapāśakalparāja 17b: oṃ nāgapāśa bandhayākaḍḍhaya dușțanāgapāśa pātaya hūṃ.

97 Jale probably stands for standard jala.

98 It seems that bhavati should be taken in the imperative or optative sense. 
smara smara tathāgatasamaye hūṃ hūṃ phaṭ svāhā | ākarṣaya nāgān bandhaya bandhaya vajrabandhena tathāgatasamādhinā sasyana mocala hūṃ phaṭ | bho dușțanāgā mātikrama | mā te mūrdhā sphuṭiṣyati | huru huru hūṃ hūṃ phaṭ svāhā | varadāya svāhā | nāgasphoṭanāya svāhā | nāgavidāraṇāya svāhā | ọ̣ svāhā | svaḥ svāhā | bhū svāhā | bhuvạ̣ svāhā | tathāgatasamaye svāhā | trailokyapūjitāya svāhā | oṃ hūṃ phaṭ phaṭ phaț phaṭ phaṭ svāhā |

[3.11] iyaṃ bho bhujagādhipates tathāgatasamayagaruḍjvālā nāma mahāhṛdayadhārạ̣i sarvadușțanāgānāṃ pratiședhāya sarvameghāśanivātāśanināśanaṃ nivāraṇaṃ sasyaparipālanaṃ ca puṣpaphalavanaspatiparipālanam amṛtaphalasampādanaṃ sukhasampattivivardhanam | sahasmaraṇamātreṇeyaṃ bhujagādhipateḥ sarvanāgamaṇḍalikā saputradārāsāmātyapravarā sapārṣadyāšíviṣasītavalāhakān vāyuvalāhakān sāmagrībhāveṇa tathāgatavacanānujñātā tathāgatasamayādhișthānena | asmin jambudvīpe paścime samaye paścime kāle sarvasasyāni sarvapuṣpaphalāni sarvadravyatṛnauṣadhyādīni saṃrakṣitavyāni paripālayitavyāni | tsarvadanyathāt kālena kālaṃ varṣadhārā-m-utș̣jatha | yathā jīvitaṃ tathā jambudvīpakānāṃ mahāpuṣpaphalasasyāni paripālayitavyāni | sarvedaṃ yathābhāvaṃ bhaviṣyatha | tathāgatānujñātayā

1 -samaye] ACDE; -samaya B • ākarșaya] BCD; ākarșaye AE • bandhaya] ABCD; bandhaye E 2 vajrabandhena] ABDE; vajravajvabandhena $C$ - sasyana] $B D$; sasvana $A$, saspana $C$, sasyata E • hūṃ] BCD; hūṃ hūṃ AE • phaț] BCDE; phaț svāhā A 3 mātikrama] BCDE; mātikra A • sphuțișyati] E; sphațiṣyati $\mathrm{ABCD}$ 3-4 AE add: huru 2 hūṃ hūṃ phaṭ svāhā <59v> varadāya svāhā | nāgasphoțanāya svāhā | (dittography) $\mathbf{4}$ varadāya] BDE; -ye AC • nāgasphoțanāya] $\mathrm{BDE}$; -ye $\mathrm{AC}<\mathrm{E} 54(13) \mathrm{v}>$ • nāgavidāraṇāya] $\mathrm{BDE}$; -ye AC $\mathbf{5}$ svāhā̄3 $<\mathrm{D} 47 \mathrm{r}>$ • -samaye] ADE; -samaya BC 6 -pūjitāya] BCD; pūjitāye AE 7 C illegible: bho bhujagādhipates tathāgatasamaya garuḍajvāāā nāma <B28r > • bhujagādhipates] BD; bhujaṃgādhipates $\mathrm{AE}$, ++++++ C 8 pratiședhāya] BC; pratișyadhāya AE, pratiședhāyam D 9 -āśani- $\left.{ }^{1}\right]$ BCDE; -āsanni- A • -āśani-2] BCDE; -āsanni- A • sasyaparipālanaṃ] BD; sampparipālaṃ A, sasyaparipālaṃ CE • ca] C; om. ABDE 10 -paripālanam] <C1029u> 11 -sampatti-] BD; -samprati- AE, +++ C <A60r>. C illegible: amṛtaphalasampādanaṃ sukhasampattivivardhanaṃ • saha-] BCDE; smaha- A • bhujagādhipateḥ] BD; bhujaṃgādhipate ACE 12 -nāgamaṇụalikā] BDE; -nāgandirīkā A, -nāgamaṇḍa++ C • -dārāsāmātya-] B; -dārotmāmātyasa- AC, -dārāsāmātyāsa- DE • pravarā] $\mathrm{ABCDEp} c$; -pravarāyā Eac 13 -valāhakān] $\mathrm{BDE}$; -valāhakāna $\mathrm{A}$, -valāhakāt C 14 paścime²] ABDE; paści C 15 -phalāni] $<$ D47v $>$ • -tṛnauṣadhyādīni] CDE; -bhṛnauṣadhyādīni AB • -rakṣitavyāni] ADE; -rakṣatavyāni B, -rakṣyatavyāni C 16 C illegible: vyāni | sarvadanyathā kālena kālaṃ • sarvadanyathā] BD; sarvadanethā AE, +++++ C, om. Tib • utsṛjatha] BCDE; usṭjatha $\mathrm{A} 17$ yathā] $\mathrm{BCDE}$; jaya $\mathrm{A}<\mathrm{A} 60 \mathrm{v}>\bullet$-dvīpakānāṃ] $\mathrm{DE}$; -dvīṣenānā A, -dvīpakānā BC • mahā-] BCE; ha- A, moha- D 18 sarvedaṃ] DE; sarvaidaṃ ABC 
One with the Vow of the Tathāgatas, hūm hūm phaț svāhā. Attract the Nāgas, bind bind with vajra-sealing, with the concentration of the Tathāgatas, sasyana, mocala hūm phat svāhā. Listen, hostile Nāgas, do not neglect [the vow]. Let your heads not burst. Huru huru hūṃ hūṃ phaț svāhā. Svāhā to the One who Grants Boons. Svāhā to the One who Crushes Nāgas. Svāhā to the One who Splits Nāgas. Om svāhā. Svah svāhā. Bhū svāhā. Bhuvaḥ svāhā. Svāhā to the One with the Vow of the Tathāgatas. Svāhā to the One Worshipped in the Three Worlds. Om hụ̈ phat phat phat phat phat svāhā.

[3.11] "O Serpent chiefs, this great heart-dhāraṇi, called Tathāgata Vow Garuḍa Flame, wards off all hostile Nāgas, destroys and keeps back all clouds, thunderbolts, winds and lightning, protects crops, guards flowers, fruits and trees, produces the fruit of immortality, ${ }^{99}$ increases comfort and welfare. O Serpent chiefs, merely upon calling to mind, all Nāga rulers ${ }^{100}$ along with their sons, wives, chief ministers and retinues [shall ward off] venomous snakes, cold spells, clouds, winds and clouds entirely by the authorization of the Tathāgata's word, with the empowerment of the vow of the Tathāgatas. All crops, all flowers and fruits, all possessions, grass, herbs and so on should be protected and safeguarded in Jambudvipa in the last time, in the last age. You should send down rain showers duly at the proper time. The great ${ }^{101}$ flowers, fruits and crops of the people of Jambudvipa should be guarded like your own life. If it is

99 "Immortality" (amṛta) is normally a reference to nirvāṇa in Buddhist sources.

100 Is this somehow connected to the chapter title?

101 This adjective seems slightly awkward here. Could it have been "all” (sarva) originally? 
vacanagurutayā atikramet | tadā sarvanāgabhavanāni prajvalitāni samprajvalitāni | ekajvālībhūtāni bhavantu | mahati nāgadurbhikṣatāni prādurbhavantu | balavihīnā vīryavinașțā bhavantu | jalaprahịnā bhavantu | bhavanaśoṣaś ca bhavantu | karkaśagātrā bhavantu | agnivālukābhayaṃ nityaṃ kṣutpipāsitā bhavantu | itaś ca tataś ca paridhāvamānāḥ saṃdagdhaprabhāḥ sūryātapaparitāpitā tasya saṃtaptaśarīrayā dahyantu | nānāvyādhyupadravopasargasamgṛhītā bhaviṣyatha | evaṃ paścime kāle paścime samaye dușțanāgāś caṇụapraduṣțāś ca dụ̣kham anubhūyante | yad imāṃ tathāgatagaruḍajvālāhṛdayaṃ nāma dhāraṇịm atikramet | tasmāt tarhi bhujagādhipate satyapratijñayā tathāgatasamayānurakṣaṇatayā bhavitavyam | sarvajambudvīpakāḥ sattvāḥ paripālayitavyāḥ | rakṣitavyāḥ sampādayitavyāḥ |

\section{[3.12] atha samantākāraparikaracchatro mahānāgarājā | sāgaraś ca} mahānāgarājā | nandopanandaś ca nāgarājāno | manasvī ca nāgarājā | huluṇụaś ca nāgarājā | varuṇaś ca | ratnajvālāsaṃdhāraṇavikasitaprakarṣaṇacūụaś ca | brahmaśīịsaś ca | trailokyavikhyātadhvajaś ca | îśvaraprabhaś ca | viśuddhaprabhāsakīrtiś ca | samantākāradhvajaś ca | mạ̣iŝīiṣaś ca |

1 C illegible: gurutayā atikramet | tadā sarvanāga • atikramet] $<$ B28v $>\bullet$ sarva-] BDE; sarvai- A, ++ C <E56(14)r> 2 bhavantu] BC; bhavatu AE, bhavantu | agnivālukābhayaṃ nityaṃ D • mahati] ACDE; +++ B 3 -vihīnā] BDE; -vihīno AC 3-4 C illegible: ṇā bhavantu | bhavanaśoṣaś ca bhavantu | karkaśagā $\quad 4$ bhavanaśoșaś] DTib; bhavanasāṣaś AC, bhuvanaśoṣaś B, varṣaṇasāyam E • ca] ABCD; om. E • karkaśagātrā] conj. Tib; karkasapa A, karkaśapatrā BDE, ++++trā C 5 tataś] conj.; mṛtaś ACDE; mṛtaś ca mṛtaś B • paridhāvamānāḥ] <A61r> 6 sūryātapaparitāpitā] BDE; sūryāteparṣaritāpitā AC $<$ D48r $>$ • saṃtapta-] ACDE; saṃbhṛpta- B • saṃtaptaśarīrayā] BD; -lā A, + C, -syā E 6-7 C illegible: rayā dahyatu|nānāvyādhyopadravopa 6 dahyantu] D; drahṛtum A, dahyatu BE, +++ C 7 -upadravopasarga-] DpcE; -opadravopasargaA, -upadravoptasarga- B, -+++++sarga- C, -upadravosaparga- Dac • paścime] ABCD; paścimeke E • kāle] ABDE; kākāle C $\quad$ 8-9 C illegible: samaye duștanāgāś caṇḍapradușțâś ca duhkham anubhūyante | yad imāṃ tathāgatagaruḍajvālāhṛdayaṃ nāma dhāraṇịm atikra <C1028d> 8 -pradușțāś] BDE; -yadușțāś A, +++ C 9 tathāgata-] BDE; tagata A, ++++ C • -yaṃ] B; -yāṃ $\mathrm{ADE},+\mathrm{C} \quad$ - tasmāt] BCDE; tasya A $\mathbf{1 0}$ bhujagādhipate] BCD; bhujaṃgādhipate AE • satyapratijñayā] $\quad C$; satyepratijñāyāṃ $\quad A$, satyapratijñāyā $\quad B D$, satyapratijñāyāṃ $\quad E$ 11 paripālayitavyāḥ] <B29r> • rakșitavyāḥ] ACDE; om. B 12 -parikaracchatro] ADE; -karikaracchatro BC • mahānāgarājā] <A61v> 12-13 A omits sāgaraś ca mahānāgarājā | nandopanandaś ca nāgarājāno | manasvī ca nāgarājā | 13 -nandaś ca] ACDE; -nanda B • manasvī] E; manasī ABCD • huluṇụaś] D; huluṇụa ABCE 14 -saṃdhāraṇavikasita-] BCDE; -dhāraṇavikalita- A 15 brahmaśīrṣaś] <D48v> • -vikhyātadhvajaś ca] BCD; -vikhyātaś cayaś ca A, -vikhyātaś cajaś ca E 16 -kīrtiś] BCDE; -kīti A • samantākāradhvajaś] BCD; samantadāradhvajaś A, samadhasaravarjaś $\mathrm{E} \bullet$ maṇišīișaś] BCDE; raṇis̄īișaś A 
otherwise and you neglect the Tathāgata's authorization and his dignity of speech, then all Nāga residences are ignited and burnt. Let them be a single mass of flame. Let there be great Nāga-famine. Let them be deprived of power, and their valour be destroyed. Let them be without water. Let there be the drying up of the residence. Let them have hard bodies. Let them always have the danger of fire-sand and be hungry and thirsty. Running around with burnt radiance, heated by the hotness of the Sun, let them be burnt with their bodies heated. They will be seized by various diseases, misfortune and trouble. The hostile Nāgas, fierce and bad, will thus experience suffering in the last time, in the last age if they neglect this dhāraṇi called Tathāgata Garuḍa Flame Heart. Therefore, O Serpent chiefs, you should abide by a true promise and by guarding the vow of the Tathāgatas. All beings of Jambudvippa should be fostered, protected and caused to succeed."

[3.12] Then Samantākāraparikaracchatra, the great Nāga king, Sāgara, the great Nāga king, Nanda and Upananda, ${ }^{102}$ Nāga kings, Manasvī, ${ }^{103}$ Nāga king, Huluṇụa, ${ }^{104}$ Nāga king, Varuṇa, Ratnajvālāsaṃdhāraṇavikasitaprakarṣaṇacūụa, Brahmaśīrșa, Trailokyavikhyātadhvaja, İśvaraprabha, Viśuddhaprabhāsakīrti,

102 Nanda and Upananda feature in many episodes of the Buddha's life. See Vogel (1926) for detailed references.

103 Cf. Strauch (2014).

104 Huluṇ̣a appears in Vajrāvalī 18.3: oṃ ananta vāsuki takṣaka karkkoṭa padma mahāpadma śańkhapāla kulika pāla devati mahādevati somaśikhi mahāśikhi daṇḍadhara mahādaṇḍadhara apalālahuluṇḍa nandopananda sāgara mahāsāgara tapta mahātapta śrīkānti mahākānti ratnakānti surūpa mahāsurūpa bhadrāhika mahodara śili mahāśili oṃ bhakṣa āgaccha āgaccha mahānāgādhipati sarva bhūr bhuvaḥ phuṃ phuṃ svāhā. 
supratiṣthitabrahmacuṇụaś ca | jvalitacūḍāvaliś ca | mahāsamudrākramaṇaś ca | samantāvalokitanetraś ca | viṣnucakravarti mahānāgarājā | sumerudhvajaś ca | samantākāravigataś ca | praharṣitavarșaṇaś ca | prasphoțanaś ca | vidyujjvālī ca | airāvaṇo mahānāgarājā | jalavāhanacitraś ca | mucilindabalaś ca | trailokyavarṣaṇaś ca | vaiśravaṇacitro mahānāgarājā | eteṣāṃ caturaśīti nāgarājasahasrāṇām pramukhānām ekaikā nāgarājāḥ saptasaptatibhir tadbhavananāgakulasahasraị̣ parivṛtā | yena bhagavāṃs tenopasaṃkrānta upasaṃkramya bhagavantam tripradakṣiṇikṛtya mahatā pūjayā pūjayitvā bhagavatah pādayor nipatya bhagavantam etad avocat | naṣțā vayaṃ bhagavan dagdhāḥ samprajvālitagātrāḥ | saṃharṣitaromaharṣaṇajātāḥ | atidāruṇāni bhagavan mantrapadāni bhāṣitāni | mahāraudradurdharṣitāḥ | yadā vayam bhagavan sarve bhagavatạ̣ purataḥ pratyakṣībhāvenāvasthitāḥ | evaṃ bhītatrastāḥ saṃharṣaṇaromakūpajātāḥ | mahādāruṇabhayābhibhūtāḥ | samvignamanasaḥ sarve sthitāh | tat katham bhagavan paścime kāle paścime samaye tathāgataparinirvṛte bhikṣavo bhavanti | raudrā arthalolupatayā śitavātāśaniṃ nivāraṇādhyavasitā bhavanti | tat kathaṃ bhagavan teșām duṣṭanāgānām pratipattavyam | katham teșām bhūyo jīvitạ̣ kariṣyanti | katham bhagavann asmadīye putrapautrā anubhavișyanti |

[3.13] atha bhagavān teșām nāgānām adhipatīnām etad avocat | maitrīvihāriṇo bhujagādhipatayạ̣ paścime kāle paścime samaye bhavitavyam |

1 -āvaliśs BCDE; -āpaliś A • -kramaṇaś] BDE; -karaṇāṃś A, -krayaṇaś C $\quad 2$-cakravarti-] B; -cakravatri- A, -cakrāvartri- C, -cakrāvatrir DE • sumerudhvajaś] $\mathrm{E}<56(14) \mathrm{v}\rangle \quad \mathbf{3}$ vigataś] em.; -toś ABC; -tāś DE • praharșitavarșaṇaś] BDE; praharșatavarșaṇaś AC • prasphoțanaś ca] ACDE; om. B • vidyujjvālī] $\mathrm{CD}$; viyujvāliś $\mathrm{A}$, vidyujvāliśs $\mathrm{BE} \quad \mathbf{4}$ jalavāhanacitraś ca] $\mathrm{ACDE}$; kulavāhanaci++ B <A62r $\quad 5$-śravaṇacitro] ABCE; -śramaṇacitro D $\mathbf{6}$-hasrāṇāṃ] $<\mathrm{B} 29 \mathrm{v}\rangle$ • ekaikā] ACE; ekekā B, ekaikī D - saptasaptatibhir] D; saptasaptati A, saptatibhi B, saptasaptatitrir C, saptasaptatitabhir E 7 tadbhavana-] AD; om. BCE • parivṛtā] ACDE; -taḥ B 7-8 tenopasaṃkrānta upasaṃkramya] B; tenopasaṃkramya ACDE $\mathbf{8}$ bhagavantaṃ] D; bhagavatas AE, bhagavantas BC $<$ D49r $>\bullet$-kṛtya] BDE; -kṛtye AC • mahatā] ACE; mahatyā BD • pūjayā] ADE; pūjanayā B, pūjarayī $\mathrm{9}$ nipatya] BD; -tye ACE 10 dagdhāḥ] BCDE; dhāḥ A • saṃharșita-] DE; saṃdūṣita- AC, sahașita- B <C1025d 11 vayam] ABpcCDE; bhavayaṃ Bac <A62v> 12 sarve] DE; sarvai A; sarva BC • -bhāvenāvasthitāḥ] BDE; -bhāvanāvasthitāḥ AC 13 bhītatrastāḥ] BCDE; hītatrastāḥ A 15 tathāgataparinirvṛte] BCDE; tathātaparivṛtate A 16 -vātāśaniṃ] BCD; -vantāsanni- A, vāntāśanniṃ E • - dhyavasitā] BCDE; -vyavasthitā A • bhavanti] <B30r> 17 pratipattavyam] DE; pratitavyam A, pratipattavya B, pratipratavyam $\mathrm{C} \bullet$ katham] $\langle$ D49v $>$ • karișyanti] AE; -ati BCD 18 asmadīye] ACE; -ya BD • anubhavișyanti] CDE; -ati A, ++ B 19 teșāṃ] AE; om. BC, steșām D • nāgānām] ABCDpcE; nāgā- Dac • avocat] <A63r> • -vihāriṇo] E; -vihāriṇām A, -vihārinā BD, -vihāriṇya C 20 bhujagādhipatayaḥ] BCD; bhujaṃādhipatayah AE. Ms E continues at [3.15] - paścime²] ABD; paści C 
Samantākāradhvaja, Maṇišīrṣa, Supratișṭhitabrahmacuṇ̣a, Jvalitacūḍāvali, Mahāsamudrākramaṇa, Samantāvalokitanetra, Viṣnucakravarti, the great Nāga king, Sumerudhvaja, Samantākāravigata, Praharșitavarșaṇa, Prasphoțana, Vidyujjvālin, ${ }^{105}$ Airāvaṇa, ${ }^{106}$ great Nāga kings, Jalavāhanacitra, Mucilindabala, ${ }^{107}$ Trailokyavarșaṇa, Vaiśravaṇacitra, great Nāga king: these leaders of 84,000 Nāga kings, ${ }^{108}$ each surrounded by 77,000 of Nāga troops belonging to their abode, approached the Bhagavān, went up to him, circumambulated him three times, worshipped him with great worship, and having bowed down at his feet said to the Bhagavān, "O Bhagavān, we are destroyed and burnt, our bodies are set on fire. The hairs of our bodies are bristling and standing erect. $\mathrm{O}$ Bhagavān, extremely dreadful mantrapadas have been uttered, greatly fierce and dangerous ones. O Bhagavān, when we all stand visibly in front of the Bhagavān, thus frightened and trembling, with the hairs on our bodies bristling, overcome with great dreadful fear, standing all with agitated minds, O Bhagavān, how will monks be in the last time, in the last age, after the Tathāgata has departed? They will be fierce and because of an eager desire for wealth they will be attached to warding off cold spells, winds and thunderbolts. O Bhagavān, how should therefore those hostile Nāgas act? How will they be revived?109 O Bhagavān, what will our sons and daughters experience?"

[3.13] Then the Bhagavān addressed those Nāga Lords, "O Serpent Lords, you should abide in friendliness in the last time, in the last age. You should conform

105 For Vidyujjvāla, a Nāgarāja of Rājag̣̣ha, see Vogel (1926: 118), where a Tibetan source is given telling how he and Girika were banished from the city. After this a drought occurred, causing crop failure and famine, and finally the king begged that the Nāgas return.

106 Usually spelt as Airāvata, this Nāgarāja is described in detail in Vogel (1926: 207-14).

107 Ususally called Mucilinda, this Nāgarāja is described in detail in Vogel (1926: 102-05). Or is it Mucilinda and Bala?

108 For lists of Nāgas, see Vogel (1926: 190-92), which also refers to the Mahāryutpatti, listing 135 Nāgas. See also Hidas (2012: 200).

109 I.e. after rituals during which they were bound and suffered. 
tathāgatasamayānukūlena bhavitavyam | kālena kālaṃ varṣadhārā-m-utṣ̣jatha | kālena kālaṃ puṣpaphalasasyāni niṣpādayatha | sarvavātameghāśaniṃ nivārayatha | mā vināśatha | tatas te bhujagādhipatayo nirupadravāḥ paścime kāle paścime samaye vihariṣyatheti | yadi samyag eva bhujagādhipatayạ̣ samayạ̣ nānurakṣatha | tenāhaṃ bhujagādhipatayo nāparādhya iti |

\section{[3.14] prathamanāgasaṃcodanavidyā |}

[3.15] athāto mūlavidyāyā upacāraṃ pravakṣyāmi nāgānāṃ cittasammatam | anayā jvalitagaruḍatejohṛdayadhāraṇyā parijapya meghamaṇụali prathamataram ākāśaṃ vyavalokya śarṣapalājāmiśraṃ caturdiśaṃ kṣeptavyam | sarvameghāśani stambhitā bhavișyanti | sarvanāgās tharatharāyamānās tiṣṭhanti | bhasmodakam ekaviṃśati vāraṃ parijapyābhiṣicyātmarakṣā kṛtā bhaviṣyati | sarșapam aștottaraśatam parijapya meghagarjanakāle sapta vārān pānīyaṃ parijapya tatạ̣ sarṣapam ākāśe kṣeptavyam | sa ākāśe meghabandhaṃ dātavyam | meghābhimukham sarvapuṣpaphalaṃ gṛhītaṃ dharaṇyāṃ patanti | mantrānusmārayitavyam | kruddhena phaṭkāro dātavyạ̣ | tribhị̣ phaṭaārair nāgā adhomukhāḥ patanti | nāgaśarīrāṇy api viśīiryante sthale patanti | dāḍimalatām ekaviṃśati vārān parijapya cakrākāraṃ sapta vārān bhrāmayet | sarvaduṣṭanāgāḥ śītavātameghāśaniyo dharaṇyāṃ patanti | saptadhā mūrdhānaḥ sphuṭanti | akṣinn sphuṭanti | sakalasāmantameghā nāgāḥ saparivārā

2 -sasyāni] ABC; -sasyā D • - -vāta-] BCD; -kāma- A 3 nivārayatha] CD; nivāreyatha A, nivārayathah $\mathrm{B} \bullet$ mā] C; no A, sā $\mathrm{BD} \bullet$-patayo] <C1027u> • paścime] ABD; paści C 4 paścime] ABD; paścima $C$ • samaye] BCD; saye A • viharișyatheti] BCD; viharirișyatheti A • eva] BCD; eka A • bhujagādhipatayaḥ] BCD; bhujaṃgādhipatayeh A 5 nānurakṣatha] ACD; nānurakșayate B • tenāhaṃ] ACD; nāhaṃ B • bhujagādhipatayo] BCD; bhujaṃgādhipatayo A • nāparādhya] $\mathrm{BCD}$; -dhye A $\mathbf{6}$ prathama-] $\mathrm{ABC}$; prathamī- $\mathrm{D} \bullet$-nāga-] $\mathrm{ABC}$; -rāga- $\mathrm{D}<\mathrm{A} 63 \mathrm{v}\rangle \bullet$ -codana-] B; -codani- AC, -cona- D 7 athāto] $<$ D50r $>\bullet$ mūlavidyāyā] BCD; -yāṃ A • upacāraṃ] ACD; -rah B • pravakṣyāmi] BCD; -vakșāmi A • cittasammatam] conj.; cittasammanam A, pittasammanam BCD $\mathbf{8}$-hṛdayadhāraṇyā] AC; -hṛdayadhāraṇyāṃ B, -hṛyadhāraṇyā D 9 prathamataram] $\mathrm{ABC}$; pramataram $\mathrm{D}<\mathrm{B} 30 \mathrm{v}>$ • kșeptavyam] $\mathrm{BCD}$; prakșatavya A 10 sarva-] ABD; sarve- $\mathrm{C}$ • bhaviṣyanti] ACD; -ati B • tharatharāyamānās] $\mathrm{CD}$; tharadharāyamānā A, tharastharāyamānās B $\mathbf{1 1}$ bhasmodakam] BCD; tasmātam A • ekaviṃśati vāraṃ] $\mathrm{ABC}$; parivāraṃ Dac, ekaviṃśati parivāraṃ $\mathrm{D} p c$ • pari-] ABC; om. D 12 bhavișyati] BC; -anti AD. Marginal addendum in A: na jānāțo vāmagātasāgātake yāta upacāra 13 tataḥ] <A64r> 14 meghābhimukhaṃ] BCD; -mutyam A 15 kruddhena] BD; krodhena A, krūḍhrena C • dātavyaḥ] BCD; -vyam A • tribhiḥ] BCD; dvibhị̣ A • phațkārair] BCD; -aị̣ A 16 adhomukhāḥ] $<$ D50v $>\bullet$ višîryante] BCD; -ate A 17 cakrākāraṃ] CD; cakāraṃ A, cakrākāra B 19 mūrdhānaḥ] $\mathrm{ABC}$; mūrdhā D <B31r> • sphuțanti $\left.{ }^{1}\right] \mathrm{BC}$; -ati AD • B omits akșīn sphuțanti • akșīn] CD; akṣī A; om. B • -sāmanta-] BCD; -sāmantaṃ A 
to the vow of the Tathāgatas. You should send down rain showers duly at the proper time. You should ripen flowers, fruits and crops duly at the proper time. You should ward off all winds, clouds and thunderbolts. Do not cause destruction. Then, O Serpent chiefs, you should roam without calamities in the last time, in the last age. O Serpent chiefs, if you do not guard the vow properly, then, O Serpent chiefs, it is not my fault.

[3.14] "This is the first spell urging the Nāgas.

[3.15] "From here onwards I will teach the offering of the root spell esteemed by the Nāgas. ${ }^{110}$ Having enchanted a mixture of mustard seeds and parched grain with this Blazing Garuḍa Power heart-dhāraṇi, and having first looked up to the sky at the sphere of clouds, [the mixture] should be thrown in the four directions. All clouds and thunderbolts will be paralysed. All Nāgas will stand trembling. Having enchanted ash-water twenty-one times, and having sprinkled it [on himself], self-protection will be established. Having enchanted mustard seeds 108 times, and enchanted drinking water seven times at the time of the rumbling of clouds, one should throw mustard seeds towards the sky. Cloudbinding should be given in the sky. Facing the clouds all seized flowers and fruits fall onto the ground. ${ }^{111}$ The mantra should be called to mind. One should utter 'phat' wrathfully. After uttering 'phat' three times, the Nāgas fall down with their faces downwards. The bodies of the Nāgas crumble to small pieces and fall onto the ground. Having enchanted a pomegranate branch twenty-one times, it should be turned in a circle seven times. All hostile Nāgas, cold spells, winds, clouds and thunderbolts fall onto the ground. Their heads burst into seven

110 The Tibetan version gives "calming the wrath of the Nāgas" (reflecting cittaśamana).

111 It is unclear what flowers and fruits are referred to here; perhaps these are similar to those mentioned in [3.9]: "The hostile Nāgas, having placed all flowers, fruits, crops, leaves and foliage in front of the Bhagavān, stood shaking and trembling in front of the Bhagavān.” 
așțottaraśatayā kruddhena bhrāmitayā dharaṇyāṃ patanti | sakalanāgabhavanam sajalaṃ savṛkṣavanașpataya ekajvālībhūtā bhavanti | sarve ca mahānāgarājā mahaujaskā maharddhikā mahatā sīrṣarogena grastā bhavanti | yadi vidyādharaḥ śīghraṃ mantrāpayati sarveșāṃ kulonmādo bhavanti | saputrapautrāḥ saparṣan savāhanā vinaśyanti | vilayaṃ yāsyanti | sarṣapān sahasravārān parijapyānāvṛștikāle bhavane kṣeptavyam | sarve ca nāgā tharatharāyanti | ekajvālībhūtaṃ bhavanasaro bhaviṣyanti | śīghram varṣadhārā-m-utș̣janti | yathākāmataḥ punaḥ punar varṣadhārā-m-utș̣janti | yadā varṣaṇa kāryaṃ tadā vidyādhareṇa sarṣapodakenāșțottaraśataṃ parijapya uccasthānam āruhya pūrvābhimukhena sthitvā pūrvasyāṃ diśi sapta udakāñjalayaḥ kṣeptavyāḥ saptavārān mantraṃ parijapya sadya sarvanāgarājāna teka madhyet saṃnipatanti | varṣadhārā-m-utsṛjanti | aruṇakāle sarṣapakun̉kumodakaṃ sammiśraṃ saptavārān parijapya caturdiśaṃ kṣeptavyam | adha ūrdhvaṃ ca kṣeptavyam | sarvaśītavātameghāśanīnāṃ samantād yojanam sīmābandho bhaviṣyati | sarvadușțanāgā baddhā bhaviṣyanti | anatikramaṇiyāḥ sarvanāgā bhaviṣyanti | kapilagomayam apatitạ̣ gṛhītvā tasyā eva ghṛtaṃ kṣiraṃ gomūtraṃ gṛhya saptabỉjakam †āḍham † miśret | tanmantreṇa navativārān parijapya tato pañcaśîrṣako nāgạ̣ kartavyaḥ| phaṇimaṇino baddhaparyañkạ̣ parivartitạ̣ śvetacandanakuṅkumena lepya śucyāsane sthāpayitavyaḥ | pațāābhiṣekaḥ kartavyaḥ | puṣpamālāṃ dātavyam |

1 așțottaraśatayā] AD; așțotara- $\mathrm{BC}<\mathrm{A64v> \bullet} \mathrm{kruddhena]} \mathrm{BCD;} \mathrm{kruḍhena} \mathrm{A} \mathrm{•} \mathrm{bhrāmitayā]} \mathrm{BCD;}$ bhāṣitayā ATib 2 savṛkșavanașpataya] BCD; -ye A • bhavanti] ACD; bhavișyanti B <C1018d > 3 mahaujaskā] A; mahaujaskā mahaujaskā BCD • śīrșarogena] AC -rogyena BD 4 yadi] $\mathrm{ABCD} p$; sa yadi Dac • mantrāpayati] ACD; -anti B $\mathbf{5}$ bhavanti] BCD; vanti A • saparșan] BD; sapārṣan AC • vinaśyanti] <D51r> $\mathbf{6}$ kșeptavyam] BCD; prakșeptavyam A 7 bhavișyanti] BCD; bhavinaśyanti A < $\mathrm{A} 65 \mathrm{r}>\mathbf{8}$ utș̣janti] $\mathrm{BD}$; utș̣kșanti AC 9 varșaṇa] ACD; varșasa B • kāryam] BC; kāre A, kāle D 10 uccasthānam] BC; uccasthām A, uccasthāne-m D • pūrvasyāṃ] ACD; +++ B <B31v> 11 udakāñjalayaḥ] D; ukājalayai A, udakājalayạ̣ BC 12 utsụjanti] Marginal addendum in A: suprabhātanali aruṇayāte jaḍoya tunu upacāra 13 aruṇakāle] $\mathrm{BCD}$; -kālena A • sarșapakuñkumodakaṃ] BC; -odakena A, -odake D • saptavārān] BCD; saptavān A • parijapya] BCD; paripya A 14 kșeptavyam ${ }^{1}$ BCD; prakșeptavyam A • kșeptavyam²] BCD; prakṣaptavyam A • -āśanīnāṃ] BCD; -āśanīnāṃ śanīnāṃ A $\langle\mathrm{D} 51 \mathrm{v}\rangle\langle\mathrm{A} 65 \mathrm{v}\rangle \quad 15$ samantād] BCD; -tā A - sīmābandho] BCD; sīnābandhaṃ A. E continues with -mābandho after a gap $<$ E58(15)r> 16 bhavișyanti $\left.{ }^{1}\right] \mathrm{ADE}$; -ati BC • anatikramaṇiyāḥ] ABCE; an++++++ C • sarvanāgā] BCDE; -nāgya A • bhavișyanti²] BCD; -ati AE • kapilagomayam] BCD; kapilojñamayenam A, kapilāgomayemam $\mathrm{E} \bullet$ apatitam] conj. Tib; apati AE, amapati BD, anapati C 17 āḍham] C; àḍha $\mathrm{ABDE}$ - miśret] $\mathrm{DE}$; -eta $\mathrm{ABC} \quad 18$ navativārān] $\mathrm{BCD}$; vativārān $\mathrm{AE} 19$ phaṇimaṇino baddhaparyańkah] BDE; phaṇimaṇino baddhaparyañkam A, ++++++++ryañkah C • -candana-] DE; -caṃndana- A, -candakaṃ B, -candra- C 20 sthāpayitavyaḥ] ABCE; -vyāḥ D <C1019u • • pațtāōhișekaḥ] AacBCDE; pațțākābhișekaḥ Apc • pușpamālāṃ] ACDE; -mālā B 
pieces. Their eyes burst. After [the branch] has been circled wrathfully 108 times, all neighbouring clouds and Nāgas with their retinues fall onto the ground. All Nāga residences along with their waters, trees and forest trees are transformed into a single flame. All great Nāga kings of great vital fluid and great supernatural power are seized by great headaches. If the spell-master recites the mantras swiftly, there will be family insanity for all of them. They will perish along with their sons and grandsons, assemblies and vehicles. They will be destroyed. Having enchanted mustard seeds a thousand times, these should be thrown into the residence at the time of drought. All Nāgas will tremble. The residence lakes will be transformed into a single flame. They will quickly send down rain showers. Again and again they will send down rain showers as it is desired. When rain is to be made, then the spell-master having enchanted mustard seed water 108 times, having climbed up to an elevated place, ${ }^{112}$ standing facing east, he should throw seven handfuls of water in the eastern direction having recited the mantra seven times; [thus] all Nāga kings meet in the middle at once. ${ }^{113}$ They send down rain showers. At dawn water mixed with mustard seeds and saffron should be enchanted seven times and thrown in the four directions. It should also be thrown downwards and upwards. There will be a sealing of the boundary for all cold spells, winds, clouds and thunderbolts as far as a yojana all around. All hostile Nāgas will be bound. No Nāgas can trespass. Having taken brownish cow dung that has not touched the ground and taking ghee, milk and cow urine, one should mix it with seven seeds and flour. ${ }^{114}$ Having enchanted it ninety times with that mantra, a five-headed Nāga should be made. It should be hooded with jewels, seated cross-legged, coiled, and having smeared it with white sandal and saffron, it should be placed on a pure seat. A consecration with a fillet should be made. A flower garland should be

112 Compare uccasthāna [1.13] [3.15] [5.6] with bhavanasara, uccasara [2.27], śaranamūrdhan [1.13], uccaśarasi, ūrdhvasarasi [4.1] and uccaśaraṇa [6.7].

113 Note the problematic Sanskrit here.

114 Cf. †ătavakat in [2.27]. Or is this related to äḍaka here? Cf. MW 134: "a measure of grain $(=1 / 4$ drona $=4$ prasthas $=16$ kudavas $=64$ palas $=256$ karshas $=4096$ māshas $;=$ nearly 7 lbs. 11 ounzes avoirdupois; in Bengal = two mans or 164 lbs. avds.).” 
saptarasikā kumbhavalayaḥ sthāpayitavyāḥ |

dadhikṣīrataṇụulakṣurasaśarkarāmākṣikaṃ phalapuṣpam tatraiva kṣeptavyam | caturasraṃ maṇ̣̣alakaṃ kartavyam | puṣpāvakīrṇaṃ kartavyam | catvārạ̣ pūrṇakumbhāḥ sthāpayitavyāḥ | catvāraḥ śarā nikhantavyāḥ | catasrạ̣ śvetapatākā bandhayitavyāḥ | baliṃ madhyamaṇụalake sthāpayitavyaḥ | catvāraḥ khadirakīlakā caturṣu koṇeṣu maṇḍalasya nikhantavyāḥ | pañcaran்gikena sūtreṇa pañcavartikena vartayitavyam | sarvatra ekaviṃśati vārān parijapya karma kartavyam | kumbhaśirasi ghaṇṭā bandhayitavyam | naladaṃ sarjarasaṃ kundurukaṃ nakhaṃ nāgapuṣpaṃ gaurasarṣapam śarkarā saha yojyam | mantreṇāșțaśatam japtena kartavyam | tena dhūpo dātavyaḥ | eșa

dhūpaḥ sarvatra prayoktavyaḥ | tato vidyādhareṇa susnātena śucivastradhāriṇā bhavitavyam | etenaiva mantreṇa upasprśanaśikhābandhasīmābandhamạ̣ḍalabandhanam vastrotkṣepanam ātmarakṣā snānaṃ kartavyam | nāgaṃ pūrvāmukhaṃ sthāpya vidyādhareṇa tadabhimukhaṃ niṣadya tenaiva mantreṇāvāhanabalipuṣpadhūpavisarjanaṃ kartavyam | tato vidyādharenāșțottarasahasram japtavyam | ekaikaṃ sarṣapam phalaṃ parijapya nāgapratimā hantavyāḥ | catvāraḥ ghṛtapradīpo dātavyāḥ | nāgānāṃ saṃsthātavyāḥ | yasyāvāhayati sa upatiṣṭhati | pūrṇe așțottarasahasrajāpena sarve mahānāgarājāno vaśyā bhavanti | sarvadā darśanaṃ dāsyanti | yathābhiprāyaṃ tat sarvạ̣ dāsyanti | sarvạ̣ ca vistareṇa prakārayanti | sarvasvajanaparivārāḥ saputrapautrā vaśyā bhavanti | sarvakarmakarā bhavanti | yathā svagṛhavat paripālayanti |

1 kumbhavalayah] BCDE; -ye A $<$ A66r $>$ 2 -taṇulula-] CE; -taṇụle- AD, -taṇdulai- B • -mākṣikaṃ] ADE; gokṣîkam B, +++ C <B32r • C C illegible: -rkarāmākṣikaṃ phalapu- • tatraiva] CDE; tataiva A, tantraiva B 3 maṇdalakam] ADE; maṇdalam B, maṇdalaka C • kartavyam $\left.{ }^{1}\right]$ ABDE; ka++ C • catvāraḥ] corr.; om. A; catvārih BCDE <D52r> 4 pūrṇakumbhāḥ] BCDE; -āṃ A • śarā] ABCE; śarā ca D • nikhantavyāḥ] BCDE; nisyantavyāḥ A $\mathbf{5}$ bandhayitavyāḥ] D; bandhitavyāh ABCE • madhya-] BD; madhye AE, ++ C • -maṇḍalake] ABDE; ++++ C 6 catvāraḥ] BCDE; om. A 8 C illegible: -pya karma kartav • karma] BDE; ka+ A, ++ C • ghaṇțā] $\mathrm{ABCE}$; ghaṇțāpațā D 9 sarjarasaṃ] BDE; sajarasaṃ AC • nakhaṃ] <A66v> 10 dhūpo] BCDE; po A • dātavyaḥ] CDE; -yam AB 11 prayoktavyaḥ] CE; -yaṃh A, -yaṃ B, -yāḥ D • -vastra-] BCDE; -vantra- A 12 mantreṇa] <E58(15)v> 13 -maṇạala-] ApcBCDE; -maṇda- Aac • vastrotkṣepanam] BDE; vastrokṣayanam $A$, vastrotkșayanam C 14 ātmarakṣā] BCDE; -rākșyam $\mathrm{A}\langle\mathrm{D} 52 \mathrm{v}\rangle \bullet$ kartavyam] $\langle\mathrm{B} 32 \mathrm{v}\rangle \mathbf{1 5}$ tadabhimukham] A; stadabhimukham BCDE • nișadya] $\mathrm{BDE}$; nikhanya AC 16 -āșțottara-] ABDE; -āșțautura- C • -sahasraṃ] ABCDpcE; śasahasram Dac • sarṣapaṃ] CE; -pa- ABD 17 parijapya] <A67r • hantavyāḥ] BDETib; kartavyā A, hanthavyāḥ C • dātavyāḥ] $\mathrm{BCDE}$; -yaḥ A <C1019d> 18 nāgānāṃ] $\mathrm{CD}$; nāgātī $\mathrm{AE}$, +gānāṃ $\mathrm{B} \bullet$ saṃsthātavyāḥ] ABCE; sasmītavyāḥ D • yasyāvāhayati] BCDE; -anti A • pūrṇe] ABDE; pūrṇa C 19 -sahasrajāpena] B; sahasraṃjāpyana $\mathrm{AE}$, -sahasraṃjāpena $\mathrm{CD}$ • sarvadā] $\mathrm{ABC}$; sarvede $\mathrm{D}$, sarveda E 20 darśanaṃ] BCDE; ḍharśānaṃ A • sarvaṃ²] BCE; sarve AD 22 bhavanti] ACDE; -ati B 
offered. Jars with seven kinds of liquids should be placed in a circuit. Curd, milk, rice grains, kșura ${ }^{115}$ with candied sugar and honey, fruits and flowers should be thrown there. A square mandalaka should be prepared. Flowers should be scattered. Four filled jars should be placed. Four arrows should be dig into the ground. Four white ribbons should be fixed. Offerings should be placed in the middle of the mandalaka. Four stakes made of khadira wood should be driven into the ground in the four corners of the mandala. This [space] should be encircled with five-coloured fivefold twine. Having recited twenty-one times everywhere, a rite should be performed. A bell should be fixed at the top of the jars. Nalada, sarja-resin, olibanum, nakha, ${ }^{116}$ nāgapuspa ${ }^{117}$ and white mustard should be joined with candied sugar. These should be enchanted with the mantra 108 times. Incense should be offered by that. This incense should be used everywhere. Then the spell-master should bathe well and put on clean clothes. Water sipping, ${ }^{118}$ the sealing of the crest, ${ }^{119}$ the sealing of the boundary, the sealing of the mandala, the putting on of clothes, ${ }^{120}$ self-protection and bathing should be performed. Having placed a Nāga facing east, the spell-master should sit down facing that, and should perform invitation, offering of flower and incense and dismissal with the mantra. Then the spell-master should do recitation for 1,008 times. Having enchanted mustard seeds and fruits one by one, the Nāga image should be hit. Four ghee lamps should be offered. They should be placed for the Nāgas. The one invited will approach. When 1,008 recitations have been made, all great Nāga kings are subdued. They will always appear. They will always provide all that is wished for. They accomplish everything in detail. All retinues of kinsmen with children and grandchildren are subdued. They do everything that is desired. They guard him as if it were their own home.

115 MW 331: "Asteracantha longifolia L.; a thorny variety of Gardenia or Randia L.; Trilobus lanuginosus L.”

116 MW 524: "Unguis Odoratus."

117 MW 533: "Mesua Roxburghii, Rottlera Tinctoria, and Michelia Champaka L.”

118 Note the standard Sanskrit form upasparśana.

119 For śikhābandha cf. e.g. Amoghapāśakalparāja 7b.

120 Cf. Amoghapāśakalparāja 9b: vastramantra ekaviṃśatijaptayā oṃ amoghavastrāṇy o(u)tkṣipāmi bodhini padme svāhā $\|$ vastrotkṣepaṇamantraḥ. 
[3.16] pañcanāgakanyārūpam guhyasthāne sthāpayitavyam | puṣpadhūpaṃ dātavyam | nirākule dhārayitavyam | aprakațaṃ na kasyacid darśanaṃ dātavyam | śucivastreṇa cchādayitavyam | yadā kāryaṃ bhavati sarṣapenāșțaśatajaptena hantavyam | sarvakāryāṇi karișyati | yatra preșayati tatra gacchati | punar apy āgacchati | svapne sarvaṃ kathayati | yathākāryam sarvakarmakaro bhavișyati | nāgapreșaka iti kathyate | yadākālameghavātāśanišītā bhaviṣyanti tadā caṇḍabijakaṃ sarṣapamiśram ekottaraśataṃ parijapya kruddhena nāgarūpaṃ tāḍayitavyam | tatkṣanāt sarvavātāśani vinaśyanti | sarve baddhā bhavișyanti | anāvṛștikāle mantra cīrikāṃ likhya raktasūtreṇa veșțayitvā ekavimisśati granthim kṛtvā nāgapratimākaṇthe bandhayitavyam | nāgamūrdhāv ekaviṃśati vārān parijapitavyam | tatkṣaṇād varṣadhārā-m-utș̣janti | yāvad icchayā varṣanti | ativrṣ̦tikāle nīlasūtrakaṃ sapta vārān parijapya sapta granthayaḥ kartavyāḥ | atiṿ̛̦̣̦ị̣ prakramișyanti | anyāni ca sarvatra kalpavidyāsādhanam | pūrvokta eșa mantraḥ | pūrvatara sapta vārān anusmārayitavyam | sarvatraiva prayujyate | 15 paṭhitena sarvatra sādhanam iti sidhyati |

[3.17] mahāgaruḍavegavajravegajvālitagaruḍahṛdayamaṇḍalī nāma dhāraṇī samāptā |

1 guhyasthāne] $\langle\mathrm{D} 53 \mathrm{r}\rangle$ • sthāpayitavyam] DE; -yā A, -yāḥ B, -yām C $\mathbf{2}$ aprakațaṃ] $<\mathrm{A} 67 \mathrm{v}\rangle$ 3 śucivastrena] $<$ B33r $>4$ sarșapenāșța-] BDE; sarșapanāșta- AC • hantavyam] BDE; hastavyam A, dantavyam C • karișyati] ACDE; -anti B • preșayati] ABCE; -yiti D $\mathbf{5}$ apy āgacchati] DE; avyāgacchati A, asyāgacchati BC • yathākāryaṃ] corr.; -kāyai A, -kārya BCDE 6 sarvakarmakaro] ABDE; karo Cac, sarvakramakaro $\mathrm{Cpc}$ - bhavișyati] ACDE; bhavanti B • kathyate] BCDE; kathete A 8 -śataṃ] ACDE; -śa B • kruddhena] BCD; krudhona AEac, kruddhona Epc • nāgarūpaṃ] BCDE; nārūpam A <E59(18)r $>$ tāọayitavyam] $<$ D53v $>$ 9 vinaśyanti] BCDE; -ati A • baddhā] BCE; saddhā A, vardhā D • bhavișyanti] BCE; -ati AD 10 likhya] BCD; likhyat $\mathrm{A}$, likhyet $\mathrm{E}<\mathrm{A} 68 \mathrm{r}>$ • ekaviṃśati] BDE; -viṃśatir AC • granthiṃ] BD; yașți A, yaștịm C, yacchiṃ E 11 bandhayitavyam] ACDE; -yā B • nāgamūrdhāv] C; -mūrdhāọh A, -mūrdhā-d B, -mūrdhnā-d DE • ekaviṃśati] BCD; eșaviṃśati AE 12 parijapitavyam] BCD; parijapyatavyam $\mathrm{AE}$ • tatkṣaṇād] BCDE; tatakșaṇād A • varṣanti] CDE; -ati AB. Marginal addendum in A: sphāciṃvāḍorāsyam vācake vidhimaḍo 13 nīla-] ABCDpcE; om. Dac • sapta ${ }^{1}$ ] $<\mathrm{C} 1020 \mathrm{u}>\bullet$ granthayah] ACDE; gra++ B <B33v> 14 anyāni] BCD; anāvṛștị AE 15 pūrvatara] ADE; pūrvottara BC • anusmārayitavyam] CDE; usmārayitavyam A, nusmārayitavyam B • prayujyate] BCD; -yujyantam A, -yujyante E 17 -jvālita-] ACE; -jvalita- $\mathrm{BD}<\mathrm{A} 68 \mathrm{v}>18$ samāptā] corr.; -tam AC, -taḥ $\mathrm{BD}$, -ta $\mathrm{E}$. D includes vegajvālitagaruḍahṛdayamaṇụalī nāma dhāraṇi samāptah as a marginal addendum $<$ D54r $>$ 
[3.16] "The image of five Nāga girls should be placed in a secret place. Flowers and incense should be offered. It should be kept in a calm place, without having been perceived; nobody should be offered a sight of it. It should be covered with a clean cloth. If there is need, it should be struck with mustard seeds enchanted 108 times. It will accomplish all enterprises. Where it is sent, there it goes. It returns again. It tells everything in his dream. What is to be done, it will accomplish all. It is called a Nāga messenger. When there are untimely clouds, winds, thunderbolts and cold spells, then, having enchanted canḍa seeds mixed with mustard seeds 101 times, the Nāga image should be struck wrathfully. From that moment all winds and thunderbolts disappear. All will be bound. At the time of drought the mantra should be written on strips of cloth, ${ }^{121}$ and having encircled [these] with red thread, twenty-one knots should be made, and it should be bound around the neck of the Nāga image. The head of the Nāga should be enchanted twenty-one times. At that moment they send down rain showers. They make rains as long as it is wished. At the time of excessive rain, having enchanted a blue thread seven times, seven knots should be made. These overpower excessive rain. Everywhere in other kinds of ritual instructions which involve spells the previously mentioned one is the mantra. First it should be called to mind seven times. It can be employed everywhere. By mere recitation there is accomplishment everywhere."

[3.17] The Great Garuḍa Thrust Vajra Thrust Blazing Garuḍa Heart Ruler Dhāraṇi has ended.

121 Cf. the Mahāsāhasrapramardanasūtra: "After writing [the spell] on strips of cloth it should be mounted on the top of great caityas, great trees and great banners" (Hidas 2013: 236). 
[4.1] athāto mūlahṛdayasyopacāravidhir bhavișyati | sahoccāritamātrayā sarvanāgās tharatharāyante | vāraṇi vātameghasya dāḍimalatayā karavīralatayā vā dhārayitavyam uccaśarasi | apatitagomayena maṇ̣alakaṃ kartavyam caturasraṃ suvibhaktaṃ svabhāgataḥ | așțau khadirakīlakān așțāngulapramāṇān nikhanet | daśasu diśāsu caturșu koṇeșu nikhanet | śarapañcakaṃ triśūlaṃ ca nikhanet | catvāri śare pañcarañgikasūtreṇa samantāta pariveștayitavyāḥ | catvāraḥ pūrṇakumbhāḥ | catvāro dhūpakațacchakāḥ | catvāra eva balikumbhāḥ sthāpayitavyāḥ | śuklabalipūrṇakaṃ madhyamaṇḍale sthāpayitavyāḥ | puṣpāvakīrṇaṃ ca kārayet | lājāsarșapam avakiret | sarve saptasaptavārān parijapya nikhantavyāḥ | sarșapodakaṃ parijaptena caturdiśam sīmābandhayet | mahān sīmābandho bhavati | samantena yojanaṃ tatra dușțanāgā na śaknuvanti avataritum | mahānāgā evaṃ sadā na śaktā akālašitavātameghāśaniṃ nipātayitum | na ca himsayituṃ na śaktāḥ | tṛ̣napatram api kadācana | sarve baddhā bhaviṣyanti | pañcabandhanapị̄itāḥ | așțamāsikam evaṃ tu sīmābandho bhaviṣyati | na yakṣā na ca bhūtâś ca rākṣasāḥ pretakumbhāṇḍaśs ca guhyakāḥ | anatikramanīya saṃsthānam | tato vidyādhareṇa maṇụalakamadhye sthitvā dāḍimalatayā saptajaptayā nāgā vārayitavyāḥ | nātikrūraṃ vārayitavyam | nāgaparyan̉kamudrā bandhayitavyāḥ | tarjanī phaṇiśiraḥ kartavyam | kanīyasīṃ tu prasārayet | eșa mudrā sarvanāgānāṃ sahapravartitamātreṇa sarvanāgāḥ pịditā bhaviṣyanti | śiro 'rti śiraśūlaṃ prādurbhaviṣyanti | yadi nāgās taṃ

1 bhavișyati] ACDE; -anti B • sahoccāritamātrayā] BE; mahoccārita- AC, sahocārita- D 2 sarvanāgās] AE; -gāḥ BCD • vāraṇī] ACE; dhāraṇī B, vāruṇī D • karavīra-] BCDE; kari- A 3 vā] $\mathrm{BCD}$; om. AE 4 caturasram] BpcCDE; caturasam A, catudarasram Bac • suvibhaktam] ACDE; -ta- B • svabhāgatạ̣] BCDTib; -bhāvataḥ AE • khadirakīlakān] ABD; -kīlakīlakān CE 5 așțāngulapramānāan] BE; -māṇam A, -māṇāṃ CD • nikhanet $\left.{ }^{1}\right]$ ACDE; nikhanaṃ B • daśasu] ABCE; daśa- D • nikhanet ${ }^{2}$ ] ACDE; -eta B 6 śarapañcakaṃ] BDE; -pañcaka A, -pañcakaṃn C • nikhanet] ACDE; -eta B • śare] ACDE; śara B • pañcarañgikasūtreṇa] $<$ B34r $><A 69 r>7$ catvāro] ABCE; catvāra D 8 -kațacchakāḥ] BCD; -kacchakāḥ A, kațakacchukāḥ E • eva] BCE; evaṃ AD <E59(18)v> 9 madhya-] BD; madhye ACE • sthāpayitavyāḥ] <D54v> 10 lājāsarșapam] BCDE; digbandhanalājāsarșapam $\mathrm{A} \bullet$ avakiret] $\mathrm{BCD}$; akiret $\mathrm{AE} \bullet$ saptasaptavārān] CDE; saptavān A, saptavārān B 11 sīmābandhayet] ACDE; sīmāṃ bandhayet B • mahān] BDE; mahāna AC 12 śaknuvanti] ACDE; -ati $B 13$ mahānāgā] ADE; -nāgāṃ $B C \bullet$ sadā] <C1022u> • nipātayitum] <A69v> 14 himsayituṃ] BCDE; -atum A • śaktāḥ] DE; śaknu A, śakyāḥ B, śakyeḥ C • tṛ̣na-] CD; bhṛna- $\mathrm{ABE}$ • baddhā] BCDE; buddhā A 15 -pīḍitāḥ] DE; -piṇdịīāḥ ABC 16 preta-] ADE; pretān B, pretā C 17 anatikramanīya] ACE; -ye BD <B34V • • saṃsthānam] ACE; -m-asthānam BD • maṇḍalaka-] BCDE; malaka- A <D55r 18 saptajaptayā] em.; saptasaptayā ABCDE • vārayitavyāḥ] BCE; vāracitavyāḥ A, vācayitavyāḥ D • nātikrūraṃ] BC; nātikara AE, nātikrameta D • vārayitavyam] ABCE; vācayitavyam D 19 tarjanī] BCDE; tajrānī A • kanīyasīṃ] CDE; -sī AB 20 eșa] ABCE; eka D • sarvanāgānāṃ] <A70r> 21 pị̣itā] BCD; piṇḍîtā AE • śiro 'rti] BDE; śirāti A, śirārti C • śira-] ABCpcDE; śi- Cac • nāgās] BCE; nāgā A, nās D • taṃ] BCE; om. A, ta D 
[4.1] "From here onwards there is the Offering Manual of the Root-Heart. Merely upon recitation, all Nāgas tremble. It wards off winds and clouds by a pomegranate branch or oleander creeper ${ }^{122}$ and it should be held at the top of the [Nāga] lake. ${ }^{123}$ A square mandalaka should be made, well proportioned by its parts, with cow dung that has not touched the ground. Eight stakes made of khadira wood and measuring eight angulas should be driven into the ground. One should drive them into the ground in the ten directions, in the four corners. Five arrows and a trident should be driven into the ground. Four arrows should be wound round entirely with five-coloured twine. Four filled jars, four ladles with frankincense and four jars of offering should be placed. One filled with white offerings should be placed in the middle of the mandala. Flowers should be scattered. Parched grains and mustard seeds should be scattered. Having enchanted all of them seven times each, all [the necessary implements] should be driven into the ground. Having enchanted mustard seed water, one should seal the boundaries in the four directions. A great sealing of the boundaries will be there. Hostile Nāgas cannot descend there all around for a yojana. Thus the great Nāgas can never hurl down untimely cold spells, winds, clouds and thunderbolts. They cannot even ever cause harm to leaves of grass. All will be bound pressed by the five bindings. Thus there will be a sealing of the boundaries for eight months. There will be no Yakșas, Bhūtas, Rākșasas, Pretas, Kumbhāṇas and Guhyakas. No one can trespass that place. Then, having stood in the middle of the mandalaka, the spell-master should ward off Nāgas with seven times enchanted pomegranate branches. They should not be warded off too fiercely. A Nāga cross-legged hand gesture should be made. The index finger should be like a serpent head. The little finger should be extended. This is the hand gesture for all Nāgas. Merely upon reciting, all Nāgas will be suppressed. Headache and migraine will arise for them. If Nāgas are desirous of destroying

122 MW 253: "Nerium Odorum."

123 Compare uccaśarasi, ürdhvasarasi [4.1] with uccasthāna [1.13] [3.15] [5.6], bhavanasara, uccasara [2.27], śaraṇamūrdhan [1.13] and uccaśarana [6.7]. The Tibetan translation gives "top of the house." 
pradeśaṃ nāśayitukāmās teșāṃ taptavālukā mūrdhni patanti | yāvanti śirapucchadaṇdikā bhavanti | tāvanti asivarṣadhārāḥ śarīre patanti | tataḥ sarvanāgā bhītās trastā vihariṣyanti | tadā jambudvīpe kālena kālaṃ varșadhārām-utș̣janti | sarvaduṣțanāgā vaśyā bhavanti | khadirakīlakam ekaviṃśativārān parijapya ūrdhvasarasi caturasram maṇḍalakaṃ puṣpāvakīrṇaṃ dhūpaṃ dattvā 5 sarṣapodakaṃ saptajaptaghațapūrṇabali nivedyaṃ khadirakīlakạ̣ madhyamaṇḍalake nihantavyam | sarvā vātameghāśaniśītadoṣā baddhā bhavanti | sarve stambhitāś ca bhaviṣyanti | yāvat kīlakaṃ noddhriyate tāvad baddhā bhavanti | sarṣapaṃ sapta vārān parijapya meghābhimukhena kṣeptavyam | sarvāśanaya udakam pravartante | karavīralatām ekaviṃśati vārān parijapya kața kartavyam | sarvatra cāśanayo baddhā bhaviṣyanti | pānīyaṃ saptajaptaṃ kṣipet | mukto bhavati | triśūlam ekaviṃśati vārān parijapya meghagarjitakāle madhye nikhantavyam | yāvan noddhriyate triśūlaṃ tāvad garjitameghābandho bhaviṣyati | uddhṛtena mokṣạ̣ | asiṃ sapta vārān parijapya nāgaparyañkamudrāṃ gṛhītvā meghābhimukhena sthātavyam | sahagṛhītamātreṇa jvālayiṣyati | sarvanāgās trāsayanti | asiṃ gṛhītvā aṣtottaraśatam parijapya kun̉kumena garuḍam tasyopari citrāpayitvā trāsayet | yathā yathā asiṃ trāsayati tathā tathā garuḍapakṣāh śarīre nipatanti | sarvanāgās trasanti | daśadiśaṃ prapalāyante | na ca śaktā bhūyo vātāśanim pātayitum | karavīrapuṣpaṃ ghṛtasarṣapābhyāṃ madhyamaṇụalake ṣaṣti vārān juhuyāt saṃvatsaraṃ sarvanāgāḥ śītavalāhakā aśani yāvad himādayạ̣ stambhayitā bhaviṣyanti | yadā varṣa kāryaṃ tadā udakaṃ pravarṣanti |

1 nāśayitu-] BCD; nāśayatu- AE • teșāṃ] BCDE; meșāṃ A • mūrdhni] D; mūddhā A, mūrdhnā BCE 2 śira-] em. Tib; sara- ABCDE - tāvanti] ACDE; om. B • tatah] BCD; tatra AE 3 jambudvīpe] ACDE; om. B <E60(19)r> 3-4 varșadhārā-m-] ApcBCDE; varșadhārā Aac 4 khadirakīlakam] BD; -kalakam ACE $\quad \mathbf{5}$ ürdhvasarasi] conj.; -saranai $\mathrm{ABCDE}\langle\mathrm{D} 55 \mathrm{v}\rangle \quad$ • maṇdalakaṃ] $<\mathrm{A} 70 \mathrm{v}>\bullet$ dattvā] $<\mathrm{B} 35 \mathrm{r}>\quad \mathbf{6}$-japta-] ACDE; -sapta- B • -pūrṇa-] ACD; -pūrṇaṃ $\mathrm{BE} \bullet$ nivedyam] ACDE; -ya B 7 madhya-] D; madhye ABCE • sarvā] BC; sarvai A, sarva- DE • -doșā] em.; -doṣa ABCDE • baddhā] em.; bandhā ABCDE 8 bhavanti] BCD; vayanti AE • sarve] BDE; sarvai A, sarva C • noddhriyate] C; nodhriyate ADE, nāddhriyante B • tāvad] BD; stāvad $\mathrm{ACE}<\mathrm{C} 1021 \mathrm{~d}>\quad 9$ meghābhimukhena] $\mathrm{BCD}$; meghāvimukhena AE 10 kṣeptavyam] BCDE; prakșeptavyam A 11 baddhā] em.; bandhā ABCDE 12 kșipet] BDE; -eta AC <A71r • bhavati] $\mathrm{ACDE}$; -anti B 13 yāvan noddhriyate] $\mathrm{BCD}$; yāvato dhīyate $\mathrm{AE}$ - tāvad] $\mathrm{BCD}$; tāvat $\mathrm{A}$, tāva $\mathrm{E}$ 14 garjita-] ABDE; garji- C • bhavișyati] <D56r $>\quad 15$ meghābhimukhena] BCD; meghāvimukhena AE 16 jvālayișyati] ADE; -anti $\mathrm{BC}<\mathrm{B} 35 \mathrm{v}\rangle \quad 18$ garuḍapakṣāh] $<\mathrm{A} 71 \mathrm{v}\rangle$ 19 trasanti] CDE; trāsayanti $\mathrm{AB}$ - daśadiśaṃ] ACDE; daśa B • bhūyo] <E60(19)v)> 20 ghṛtasarṣapābhyāṃ] AC; -yāṃ matvā BDE • madhya-] ACDE; madhye B 21 śitavalāhakā] ABDE; -valāhako C • himādayaḥ] conj. Tib; vīpādayeh AE, vīpādayah BCD 22 stambhayitā] DE; tambhāya tāvad A, tambhayitā B, tambhayitā tāvad C • bhaviṣyanti] BCDE; -ati A • yadā] ACDE; ya B • varșa] ACDE; varșem B • kāryaṃ] ACDE; kārāṃ B • pravarșanti] ABCE; -ati D 
that province, hot sand will fall on their heads. As many heads, tails and trunks they have, that many sword-rain showers fall on their bodies. Then all Nāgas will roam terrified and frightened. Then they send forth rain showers in Jambudvipa duly at the proper time. All hostile Nāgas will be subdued. Having enchanted a stake made of khadira wood twenty-one times, flowers should be scattered and incense offered for a square mandalaka above the lake, ${ }^{124}$ and having presented an offering of mustard seed water and filled jars enchanted seven times, the stake made of khadira wood should be driven into the ground in the middle of the mandalaka. All disadvantages resulting from winds, clouds, thunderbolts and cold spells will be bound. All will be stopped. Until the stake is driven out these remain bound. Having enchanted mustard seeds seven times, these should be thrown towards the clouds. All thunderbolts produce water. ${ }^{125}$ Having enchanted oleander creepers twenty-one times, a bracelet should be made of this. Thunderbolts will be bound everywhere [for him]. One should throw water enchanted seven times. The [lightning] will be released. Having enchanted a trident twenty-one times, it should be driven into the ground in the middle [of the mandalaka] at the time of the rumbling of clouds. Until the trident is driven out the binding of the rumbling clouds will remain. By driving it out there is release. Having enchanted a sword seven times and having made the Nāga crosslegged hand gesture, one should grab [the sword] and stand facing the clouds. Merely upon grabbing [the sword] it is set on fire. All Nāgas are frightened. Having taken a sword, enchanted it 108 times, and painted a Garuḍa on it with saffron, it should be waved. As much as one waves the sword, that much the wings of Garuda fall on the [Nāgas'] body. All Nāgas are frightened. They flee to the ten directions. They are unable to hurl winds and thunderbolts again. One should offer oleander flowers with ghee and mustard seeds sixty times in the middle of the mandalaka: for a year all Nāgas, cold spells and clouds, thunderbolts and even snow and so on will be stopped. When rain is to be made, then

124 Compare ūrdhvasarasi with uccaśarasi [4.1], uccasthāna [1.13] [3.15] [5.6], bhavanasara, uccasara [2.27], śaraṇamūrdhan [1.13] and uccaśaraṇa [6.7]. The Tibetan translation gives "top of the house."

125 Cf. [6.5]. 
madhusikthamayaś caturañgulapramāṇas triśīrṣā nāgaḥ kartavyaḥ | lājāsarṣapam avakiret | suvarṇena cchādayitavyạ̣ | śuklavastram upari sthāpayitvā sahasravārān parijaptavyam | nava kulālaṃ kumbham ādāyāspṛștam tatra madhye sthāpayitavyam | śirovastreṇācchādayitvā mudrayitavyam | kumbhaṃ sthāpayitavyam caturasram gomayamạ̣ḍalakam kartavyam | lājāsarṣapā avakiretavyāḥ | dhūpo dātavyạ̣ | tatra kumbhaṃ sthāpayitvā mantra-m-āvartayitavyāḥ | dāọimalatāṃ sapta vārān parijapya tayaiva latayā kumbhaṃ madhuramadhuram āhantavyam | sarvāśanayạ̣ kumbhamadhye saṃkrāmanti | sarvanāgā vaśyā bhavanti | sa ca nāgaḥ sikthakamaya yasya nāgarāja nāma sthāpayitavyam | yasya nāmnā vidyām āvartayati sa nāgo bhavati | saparivāro 'grata upatiṣthati | atha brāhmaṇarūpako yam ājñāpayati tat sarvaṃ karoti |

[4.2] adhārmikasya nāgarājasya vișayāparipālakasya sasyapuṣpaphalavināśakasya tasya ca nāgabhavanam upari gatvā susnātena śucivastradhāriṇā ekaviṃśati vārān vidyā-m-āvartayitavyā | tato nāgabhavanāt vṛddhavṛddhāḥ striyo nirgacchanti | tāḥ kathayanti | kiṃ vidyādhara kariṣyasi | nālapitavyam | vajreṇa bhūmis tāọayitavyā phaṭkāraś ca kartavyaḥ | sā ca

1 -siktha-] corr.; -sikta- ADE, -śikta- BC • caturangulapramāṇas] DE; -aṃ AC, -a- B • trišîrṣā] BCDE; striśīișā A $<$ D56v $\bullet$ kartavyah] BDE; -vyam AC 2 lājāsarṣapam avakiret] BCDE omit this sentence - suvarṇena] em.; suvarne AE, suvarṇa BCD • cchādayitavyaḥ] conj. Tib; nādayitavyah ACDE, nādayitavyam B $\quad 3-5$ A omits (eyeskip): -payitvā sahasravārān parijaptavyam | nava kulālaṃ kumbham ādāyāsp̣̣ștam tatra madhye sthāpayitavyam śirovastreṇācchādayitvā mudrayitavyam | kumbhạ̣ sthāpayitavyaṃ caturasraṃ 4 ādāyāsprșțaṃ] BDE; ādāyāsyaștạm AC 5 mudrayitavyam] <C1024d> • sthāpayitavyaṃ] ABC; sthātavyaṃ D, sthātavyaṃś E <B36r> • caturasraṃ] BD; om. A, catusraṃ CE $\mathbf{6}$ avakiretavyāḥ] $<$ A72r $>$ dātavyaḥ] AC; -āḥ BDE • kumbhaṃ] E; kumbha ABD, kumaṃ C 7 sthāpayitvā] ABCE; sthāpayiyitvā D • āvartayitavyāḥ] BCDE; āvartavyāḥ A • parijapya] CDE; parijapyaḥ A, parijapet B $\mathbf{8}$ tayaiva latayā] CDE; om. A, yaiva lata B • àhantavyam] BCD; ākartavyam A, āhartavyam E • sarvāśanayaḥ] BCDE; sarvāśanayena A 9 saṃkrāmanti] CDE; -ati AB • sarvanāgā] $B C D$; -nāgagā $\mathrm{AE} \bullet$ vaśyā] $\mathrm{BCD}$; vayasyā $\mathrm{AE} \bullet$ bhavanti] $\mathrm{BCDE}$; -ati A • sa ca nāgaḥ] BCDE; sa ca najña A 10 sikthakamaya] BCDE; siktakamaya A • nāgarāja] BCDE; -rājā A • nāma] BCDE; om. A 11 sa] ACDE; su B • saparivāro] BCDE; -vārā A • 'grata] ACDE; 'grati B • upatișțhati] BCDE; upariștati $\mathrm{A}<\mathrm{D} 57 \mathrm{r}>\mathbf{1 2}$ àjñāpayati] $\mathrm{BCDE}$; jñāpayati $\mathrm{A} \quad 13$ adhārmikasya] $\mathrm{ABCE}$; adhṛtmikasya D • -paripālakasya] $\mathrm{BCDE}$; -parivārakasya A 14 nāgabhavanam] $<\mathrm{A} 72 \mathrm{v}\rangle$ 15 -dhāriṇā] $\mathrm{BCD}$; -dhāriṇyā $\mathrm{AE} \bullet$ vidyā-m-] $\mathrm{BC}$; vidyā $\mathrm{ADE} 16$ striyo] $\mathrm{BCDE}$; śriyo $\mathrm{A}<\mathrm{B} 36 \mathrm{v}>$ <E60(19)bisr)> 17 nālapitavyam] BCDE; mālapitavyam A • vajreṇa] BCD; vajre AE • tāḍayitavyā] A; -vyāḥ BCDE • kartavyaḥ] BE; kartavyam A, markavyam C, kartavyāḥ D 
they rain down water. A three-headed Nāga should be made of wax measuring four angulas. ${ }^{126}$ One should scatter parched grain and mustard seeds. It should be covered with gold. ${ }^{127}$ Having placed white cloths on its top, it should be enchanted a thousand times. Having taken a new unused potter's pot, it should be placed there in the middle. Having covered it with head-cloth, it should be sealed with symbols. A jar should be placed and a square mandalaka of cow dung made. Parched grain and mustard seeds should be scattered. Incense should be offered. Having placed a jar there, the mantra should be recited. Having enchanted a pomegranate branch seven times, the jar should be struck with that branch softly. All thunderbolts go into the jar. All Nāgas are subdued. As for the Nāga made of wax, by which Nāga king it is named after and in whose name the spell is recited, it becomes that Nāga. It appears before him with its retinue. What he commands from the one in the form of a Brahmin he does that all. ${ }^{128}$

[4.2] "Having gone above the residence of that unrighteous Nāga king who does not guard the province and destroys crops, flowers and fruits, the well-bathed one who wears clean clothes should recite the spell twenty-one times. Then very old women come out of the Nāga residence. They say, 'What are you doing spellmaster?' One should not talk to them. Having struck the ground with a vajra, a 'phat' sound should be made. The old woman says passionately, 'O Sir, I am

126 See also [5.6] for a wax Garuḍa figure. One may wonder whether such a wax figure is the final stage in production like an effigy made of dough (see [2.27]) or it is employed in a lost wax metal casting method (many thanks to Dr. John Guy for this suggestion). For the use of wax frog statuettes in highland Nepal rituals see Ramble (2008: 174). For an example of the lost wax technique in mediaeval Nepal see Tanemura (2004: 261-62, 265).

127 Amoghapāśakalparāja 29a: māṃ amogharājajaptena aṣtottarasahasrāṇi kārayeta nnāgamaṇ̣aliṃ tṛsīịsakaphaṇākāram parimaṇụalena suvarṇnena cchādayitvānubandhayi yatra yatra șaṭkam patitam pāśam uttamam vidyādhareṇa śuci bhūtvā susnātaśucivastradhārakāḥ.

128 Note that brāhmaṇarūpako should most likely be understood as an accusative. 
vṛddhikā cchandamāna kathayati | marami marami bhavan bhavanaṃ praviśanti | bhavananivāsinaḥ kathayanti | kim eșyasi | nișthuro vidyādharo bhavanasare tișthati | atha nāgo bhītatrastaśarīro dārakarūpam āsthāya vidyādharasyāgrata upatișthati | bho vidyādhara kiṃ kariṣyasīit | vidyādhareṇa pūrvamantra uccārayitavyaḥ | dāḍimalatayā kruddhena bhūmi tāḍayitavyā | sarvājñāṃ bho vidyādhara kị̣ kariṣyāmīti | tato vidyādhareṇa vaktavyam | tathāgatasamayān pālayasva | sarvam iti paripālayāmi | vidyādharo vakṣyati daśakuśalān g̣̣hṇa nāga | g̣̣hṇāmi vidyādhara | triśaraṇam anug̣̣hṇasva nāga | anugṛhṇāmi vidyādhara | uddhara kilam | noddhartavyam | evaṃ vaktavyam anug̣̣hṇasva tathāgatasamayaśikṣām | tataḥ kỉlakillakam uddharāmi | tataḥ sa nāgaḥ saparivāraḥ pādayoḥ patati | triśaraṇagamanaṃ daśakuśalakarmapathāny anusmarāmi pradātavyāni | samayānugrāhayitavyāḥ tataḥ kīlakam uddharitavyam | tatraivāhāraḥ kartavyaḥ | sarvanāgā vaśyā bhavanti | yathā yathā kāma karaṇīāni svāni gṛhavat prativasanti | sarvakāryāni ājñākaro bhaviṣyanti | yatra preșayati tatra gacchati | sarvakāryaṃ karișyanti | na 15 ca bhūya tasya nāgakulasya duṣțanāgā bhavanti | kālena kālaṃ varṣadhārā-mutș̣janti | kālena kālaṃ sasyā niṣpādayanti | patrapuṣpaphalāni palāśādīn

1 bhavan] conj.; bhagavan ABCDE, om. Tib • bhavanam] BCE; om. A, bhagavan D 2 bhavana-] ACDE; bhuvana- B • eșyasi] corr.; paśyasi ACDE, eśyasi B • -dharo] AD; -dharā BCE 3 bhavanasare] BCDE; -saro A • - trasta-] CDE; -tra- A, -trastā- B $\angle \mathrm{D} 57 \mathrm{v}\rangle \quad$ āsthāya] ABCE; sthāya D 4 -āgrata] conj.; -āyata $\mathrm{ADE}$, -āya $\mathrm{B}$, -āgra $\mathrm{C}<\mathrm{A} 73 \mathrm{r}>\mathbf{5}$ uccārayitavyaḥ] BD; -yam AC, yaṃh E • -latāyā] BDE; -layā AC • kruddhena] BCDE; krodhena A • bhūmi] AD; bhūmiṃ BCE • tāḍayitavyā] em.; -yah A, -yāḥ BCDE $\mathbf{6}$ sarvājñāṃ] em. Szántó; sarvajñā A, sarvajñām BCDE • bho] BCDE; om. A • karișyāmīiti] <C1025u> 7 pālayasva] BCDE; yāsasva A • sarvam iti] conj.; sarvakșiti ABCDE - vakṣyati] E; vakșati ABCD 8 daśakuśalān] BD; daśakulona A, +++++ C, daśakulān E 8-9 C illegible: triśaraṇam anug̣̣hṇasva nāga | anug̣̣hṇāmi vidyādharah | uddhara kỉlam | noddharta $\mathbf{8}$ triśaraṇam] BDE; trisaram A, ++++ C • anugṛhṇasva] ADE; -g̣̣hṇa B, +++++ C 9 anug̣̣hṇāmi] BE; anug̣̣hṇasi AD, +++ C • kīlam] <B37r > • noddhartavyam] ADE; nauddhartavyam $\mathrm{B},+++$ vyam $C \quad \mathbf{1 0}$ anug̣̣hṇasva] ACDE; -tva B • tathāgata-] CDE; tathāta- A, tathata- B • uddharāmi] <A73v> 10-11 sa nāgaḥ] ABCDpcE; om. $\mathrm{Dac} 12$-pathāny] BD; -pathyāṃny $\mathrm{AE}$, -pathyāny C • anusmarāmi] BD; anusmaraṇāti $\mathrm{AE}$, anusmaryāma $\mathrm{C}<\mathrm{D} 58 \mathrm{r}>\quad$ - $\quad$ samayānugrāhayitavyāḥ] DE; -vyā A, -vyaḥ B, -vya C 13 tatraivāhārah] BCDE; tataivohārah A • vaśyā] ACDE; bhasyā B 14 gṛhavat] ABCE; gahravat D 15 preșayati] BD; -anti ACE • karișyanti] B; -ati ACDE <E60(19)bisv> 17 sasyā] <A74r • • patra-] em.; yatra $\mathrm{ABCDE} \bullet$-phalāni palāśādīn] ACDE; -phalāśādīn B 
dying, I am dying.' ${ }^{129}$ He enters the residence. ${ }^{130}$ The inhabitants of the residence say, 'What do you wish?' The spell-master stands in the residence lake firmly. Then the Nāga, his body terrified and frightened, assumes the form of a boy and appears in front of the spell-master, 'Listen, $\mathrm{O}$ spell-master, what are you doing?' The spell-master should utter the previous mantra. The ground should be struck with a pomegranate branch fiercely. 'Listen, O spell-master, what is your command?' Then the spell-master should say, 'Keep the vows of the Tathāgata.' 'I shall keep them all.' The spell-master says, 'O Nāga, take up the Ten Righteous Actions.'131 'O spell-master, I shall take them up.' 'O Nāga, receive the Threefold Refuge.' 'O spell-master, I shall receive. Drive out the stake.' The stake should not be driven out. It should be said, 'Foster the Tathāgata's vows and precepts. Then I will drive out the stake.' Then the Nāga falls at his feet with his retinue. He should be given [the following words]: 'I shall keep in mind the Threefold Refuge and the Ten Righteous Actions.' The vows should be caused to be taken up, then the stake should be driven out. They should eat together there. All Nāgas are subdued. As he wishes his own things to be done, he dwells as if he was at home. They will follow the orders for all things to be done. Where he sends them there they go. They will do everything. There will not be hostile Nāgas in that Nāga family thereafter. They send down rain showers duly at the proper time. They ripen crops duly at the proper time. They ripen leaves, ${ }^{132}$

129 Note marami for standard marāmi. Such a form occurs in the Hevajratantra, albeit in a markedly Middle Indic environment.

130 For visits to Nāgaloka by the Brahmin Uttan்ka, see Vogel (1926: 61-66). For descriptions of their subterranean habitats (pātāla), see the Viṣnupurāṇa and the Pātālakhaṇda of the Padmapurāna (Mahalingam 1965: 7-10).

131 BHSD 170: "the avoidance of taking life, theft, adultery, lying, harsh speech, spiteful speech, idle speech, covetousness, malevolence and heresy." Note that there are minor variations in sources.

132 The Tibetan version gives "there" = tatra for yatra/patra. 
niṣpādayanti | na ca bhūya upadravaṃ kariṣyanti | paṭhitasiddhā mahādhāraṇi | sarvakarmasu prayoktavyam sarvakarmasiddhih paramasiddhir anuttarā-m-iti |

[4.3] mūlamantravidhisopacāraḥ samāptaḥ |

1 niṣpādayanti] ADE; -ati B, -a+C $\bullet$ na ca bhūya] ADE; +++ya B, ++++ C • upadravaṃ] ABDE; ++++ C • pațhita-] ABDE; pațhi- C $\mathbf{2}$-siddhih paramasiddhir] BCDE; -siddhir A • anuttarā-miti] BCDE; anuttaram iti $\mathrm{A}\langle\mathrm{B} 37 \mathrm{v}\rangle \mathbf{3}$ samāptaḥ] $\langle\mathrm{D} 58 \mathrm{v}\rangle$ 
flowers, fruits, foliage and so on. They will not cause misfortune again. This great dhāraṇi succeeds when recited. It should be used in all deeds, there is success for all deeds, the highest unrivalled success.”

[4.3] The Manual of the Root Mantra with the Offering ends here. 
[5.1] atha garuḍarājā yena bhagavāṃs tenāñjalim praṇamya bhagavantam etad avocat | ahaṃ bhagavan sarvanāgānāṃ hṛdayajvālanīṃ sarvākālavātameghāśaninivāraṇị̣̄ sarvapuṣpaphalaniṣpādanīm sarvapṛthivīrasasamarthavivardhanīm vajratuṇ̣ajvālavidyun nāma dhāranīm bhāṣișye | tad bhagavān adhitișțhatu sarvasattvānām arthāya sarvāsā̄paripūraṇāya ca |

[5.2] atha bhagavān mahāgaruḍendram etad avocat | adhișthitaṃ mayā mahāgaruḍādhipate vajratuṇ̣ā nāma dhāraṇī gañgānadīvālukāsamaiḥ koṭiśatasahasrais tathāgatair arhadbhị̣ samyaksambuddhair adhișthitā | bhāṣasva garuḍādhipate dușțanāganigrahārtham |

[5.3] atha garuḍarājā imāṃ vajratuṇụā nāma dhāraṇịm bhāṣate sma |

namo ratnatrayāya | namaś caṇḍavajrapāṇaye mahāyakṣasenāpataye | namas trailokyādhipataye | namaś caturṇāṃ mahārājānām | oṃ vajratuṇ̣̣e | tuṇ̣̣e tuṇ̣e | mahātuṇḍe | tuṭi tuṭi | vajraśikharatuṇ̣̣e |

maṇikanakavicitrābharaṇavibhūṣitaśarīre | hūṃ hūṃ hūṃ phaṭ phaṭ phaṭ phaṭ | 15 nāgarājavidrāpaṇahṛdayam | sphoțaya vajratuṇḍena svāhā | sarvākālameghāśaniṃ nivāraya hūṃ hūṃ phaṭ svāhā | mahāvajrajvālāya svāhā | sarvadușțanāgavināśanāya svāhā | garuḍahṛdayāya svāhā | garuḍatuṇ̣̂āya svāhā | suvarṇapakṣanipātanāya svāhā | oṃ dhuru dhuru svāhā | muru muru

1 garuḍarājā] AE; garuḍarājāḥ BC, garudharājā D $\quad$ 1-2 C illegible: yena bhagavāṃs tenāñjalim praṇamya bhagavantam etad avocat 1 -vantam] BDE; -vatam A, ++ C 4-5 C illegible: -yun nāma dhāraṇị̣ bhāṣiṣye | tad 4 -jvāla-] conj. Tib; -sera- AE, -sela- B, ++ C, -se- D <C1017d > <A74v> 5 bhāṣișye] BE; șipya A, +++ C, bhāṣișya D • adhitișțhatu] em.; adhitișțha 'ham tu A, adhitișțhāhartu B, adhitișțha++ C, adhitișțhāhaṃtu DE $\mathbf{6}$-pūraṇāya] B; -pūraṇārthāya ACDE • ca] C; om. ABDE 7 mahā-] BCDE; ma- A 8 mahā-] ABCpcDE; om. Cac • nāma] BCD; om. AE 9 tathāgatair] BCDE; -aiḥ A 10 -nāga-] corr.; -nāgā- $\mathrm{ACE}$, -nāgām $\mathrm{B}$, -nāgān D 11 imāṃ] <D59r> • nāma] BC; om. ADE • bhāṣate] <B38r> 12 -yakṣa-] ABDE; -ya- C 13 caturṇāṃ] <A75r> 13-14 tuṇ̣̣e tuṇ̣e | mahātuṇ̣̣e] CDE; om. A, tuṇ̣a tụ̣̣a mahātuṇ̣a B 15 phaṭ phaṭ phaṭ phaț] BCDE; phaț phaț phaț A <E61(20)r $>16$-vidrāpaṇa-] D; -vidrāpaṇi- ABCE • sphoțaya] $\mathrm{BCD}$; -ye $\mathrm{AE}$ • vajratuṇụena] $\mathrm{BCD}$; tuṇ̣e vajratuṇụe $\mathrm{A}$, vajratuṇḍe $\mathrm{E} \quad 17$ sarvā-] ACDE; sarvāni B • nivāraya] BCD; -ye AE • svāhā²] ApcBCDE; svā Aac 18 -vināśanāya] BC; -vināśanāye A, -nāśanāya $\mathrm{D}$, -vināśāye $\mathrm{E} ・$ garuḍahṛdayāya] $\mathrm{BCD}$; -ye $\mathrm{AE} \bullet$ svāhā²] ApcBCDE; svā Aac • garuḍatuṇ̣āya] BCD; -ye AE 19 suvarṇapakṣa-] ACDE; suvarṇākṣa- B • dhuru1] ACDE; ++ B 19-110,1 muru muru svāhā] D; oṃ muru 2 svāhā AE, om. BC 
[5.1] Then the Garuḍa king, having bowed down in front of the Bhagavān with his hands put together, addressed the Bhagavān, "O Bhagavān, I am going to teach the dhäraṇi called Vajra Beak Blazing Thunderbolt which burns the heart of all Nāgas, wards off all untimely winds, clouds and thunderbolts, ripens all flowers and fruits and is able to increase all earth-sap. Therefore let the Bhagavān give his empowerment for the benefit of all beings and the fulfilment of all wishes.”

[5.2] Then the Bhagavān addressed the great Garuḍa chief, "O great Garuḍa chief, the Vajra Beak dhâraṇi is empowered by me, it is empowered by ten million hundred thousand Tathāgatas, Arhats and Perfectly Awakened Ones, equalling the sand particles of the Gangā river. Expound this, O Garuḍa chief, for the sake of the subjugation of hostile Nāgas."

[5.3] Then the Garuḍa king taught this Vajra Beak dhāraṇī,

"Veneration to the Three Jewels, veneration to Candavajrapanni, the great leader of Yakșas. Veneration to the chief of the Three Worlds. Veneration to the Four Great Kings. Om $O$ Vajra Beak, O Beak, O Beak, O Great Beak, tuți tuți, O Vajra-pinnacle Beak, $O$ the One with a Body Decorated with Jewels, Gold and Wonderful Ornaments. Hūm hūm hūm phat phat phaț phaț. The Heart[-mantra] which Puts Nāga kings to Flight. ${ }^{133}$ Burst with a Vajra Beak svāhā. Ward off all untimely clouds and thunderbolts. Hūṃ hūṃ phaț svāhā. Svāhā to the Great Vajra Flame. Svāhā to the One who Destroys all Hostile Nāgas. Svāhā to the Garuḍa Heart. Svāhā to the Garuḍa Beak. Svāhā to the One who Strikes with Golden Wings. Om dhuru dhuru

133 Vidrāpaṇa, standing for standard vidrāvaṇa, is a form attested in various Buddhist ritualistic sources. 
svāhā | turu turu svāhā | ruṭ ruṭ ruṭ ruṭ ruṭ || 5 || hūṃ hūṃ hūṃ hūṃ hūṃ hūṃ hūṃ hūṃ hūṃ hūṃ || 10 || phaṭ phaṭ phaṭ phaṭ phaț || 5 || svāhā |

\section{[5.4] sahabhāṣitamātrāyāṃ garuḍenāsyāṃ vajratuṇ̣adhāraṇyām} aśîtikoṭiniyutaśatasahasrāṇi mahānāgarājānām adhomukhaṃ prapatitāni prasvinnagātrāṇi samprajvalitāni śarīrāṇi sammūrcchitāni dharaṇîtale parivartayan mahādāruṇāni mahādhāraṇīmantrapadāni bhāṣitāni sarve tharatharāyamānaśarīrā bhagavataḥ pādayoḥ praṇipatyaivam āhuh | trāyatu bhagavan trāyatu sugata | na vayaṃ bhagavan bhūyo jambudvīpam vināśayiṣyāmahe | na bhūyaḥ puṣpaphalasasyāni vināśayișyāmahe | caityabhūto 'yaṃ pṛthivīpradeśeti bhagavan dhārayiṣyāmahe | yatrāyam mahākalparājā pracarișyati tatreyaṃ vajratuṇ̣ā dhāraṇi pracariṣyati | tatra vayam bhagavan satatasamitam tathāgatacaityasamaṃ dhārayiṣyāmaḥ | satatasamitaṃ tatra pradeśe nagare vā janapade vā karpaṭe vā araṇyāyatane vā grāme vā gṛhe vā vihāre vā rakṣāvaraṇaguptiṃ saṃvidhāsyāmaḥ | sarvaśitavātāśani-akālameghān nivārayiṣyāmaḥ | snigdhaśarīramanojñasurabhisamṛddhatīkṣnāni rasāni sarvapuṣpāni phalasasyāni niṣpādayișyāmaḥ | sarvakalikaluṣadurbhikṣaduruktadurnimittā praśamayiṣyāmaḥ | kālena kālaṃ varșadhārā-m-utsṛjāmaḥ | sasyāś caiva puṣpaphalāni niṣpādayiṣyāmaḥ | sarvadamiśamaśakaśalabhasarīṣ̣pa-

1 turu turu] CDE; oṃ turu turu $\mathrm{AB}$ • ruṭ ruṭ ruṭ ruṭ ruṭ 5] ABCE; ruṭ $5 \mathrm{D}$ 1-2 hūṃ hūṃ hūṃ hūṃ hūṃ hūṃ hūṃ hūṃ hūṃ hūṃ 10] ABCE; hūṃ $10 \mathrm{D}<\mathrm{A} 75 \mathrm{v}>2$ phaț phat phat phaț phat 5] BCE; phaț phaṭ phaț phaț phaț A, phaț $5 \mathrm{D} \quad 3$-mātrāyāṃ] $<\mathrm{D} 59 \mathrm{v}\rangle$ • garuḍenāsyāṃ] BDE; garuḍarābhyāṃ AC • - -tuṇ̣a-] CDE; -tunḍe- A, -tuṇ̣ā- B • -dhāraṇyām] em.; -dhāranininyām A, -dhāriṇyām $\mathrm{BCDE} \quad 4$-sahasrāṇi] $\langle\mathrm{B} 38 \mathrm{v}\rangle \quad$ 4-5 C illegible: mahānāgarājānām adhomukham prapatitāni prasvinnagātrāṇi sampra- 4 adho-] BDE; adhya- $\mathrm{A},++\mathrm{C} \bullet$-patitāni] ADE; -patitam | B, ++++ C 5 prasvinna-] ADE; tāni prasvinna- B, +++ C • -jvalitāni] ABDE; -jvālitāni C $<\mathrm{C} 1018 \mathrm{u}>\mathbf{6}$-vartayan] $\mathrm{BCD}$; -vartayen $\mathrm{AE} \bullet$ sarve] E; sarva- $\mathrm{ABCD} 7$ praṇipatyaivam] em. Tib; prațịtamjenam A, parisvahyevam B, payișțamjevam C, parișvamijavam $\mathrm{D}$, payișțam hy evam $\mathrm{E}$ • trāyatu] BCDE; -antu A 8 bhagavan ${ }^{1}$ ] A; -vān BCDE • trāyatu] BCDE; -antu A 9 vināśayișyāmahe $\left.{ }^{1}\right]<\mathrm{A} 76 \mathrm{r}>\mathbf{1 0}$ caityabhūto] $\mathrm{BCD}$; caityaṃbhūyo $\mathrm{AE} \bullet$ bhagavan] $\mathrm{ABE}$; -va $\mathrm{CD}$ 11-12 D includes dhāraṇi pracarișyati | tatra vayam bhagabhagavan satatasamitaṃ tathāgatacaityasamaṃ dhārayi as a marginal addendum. 11 pracarișyati²] BDE; -yatị A, -yanti C 12 bhagavan] ABCE; om. Dac, bhagabhagavan Dpc • satatasamitam] BCD; -tas AE • -samaṃ] BCDE; -saṃ A • dhārayiṣyāmaḥ] BCDpcE; dhārayiṣyati A, dhārayidhārayiṣyāmaḥ Dac <D60r> 13 karpațe vā] BC; om. A, karșate vā D, karvate vā E • vā̄u ABCE; dvā D 14 vihāre vā] $\mathrm{ABC} p \mathrm{DE}$; om. Cac <E61(20)v> • saṃvidhāsyāmaḥ] <B39r> 15 akālameghān] CD; akālameghā AE, kālameghān B 16 -samṛddhatīkṣnāni] BCD; -samṛddhavatīnjñāni A, samṛddhavatīkṣnāni E $\langle$ A76v> 17 phala-] BD; sala- AE, bhala- C • -kaluṣa-] BCDE; -kalaluṣa-A • -durukta-] ACDpcE; -duruktā- BDac • -durnimittā] BC; -dunimita A, -durnittā DE 18 kālena] BCDE; om. A • utș̣jāmaḥ] BCDE; utș̣jīnaḥ A • caiva] BCDE; ca A 19-112,1 -śalabha-] BCDE; -labha- A • -maṇụūkatryambukamakșika-] BCDE; -maṇụamakșika- A 
svāhā. Muru muru svāhā. Turu turu svāhā. Ruṭ ruṭ ruṭ ruṭ ruṭ. Hūm hūṃ hūṃ hụ̣̄ hūṃ hūṃ hūṃ hūṃ hūṃ hūṃ. Phaț phaṭ phaț phaț phaț."

[5.4] Merely upon the Garuḍa's uttering this Vajra Beak dhāraṇi, eighty times ten million million hundred thousand great Nāga kings fell with their faces downwards, with perspiring bodies, blazing bodies, being unconscious, rolling on the ground [and said,] "greatly ferocious great dhâraṇi-mantrapadas had been uttered." Falling at the feet of the Bhagavān all said with trembling bodies, "Save us, O Bhagavān, Rescue us, O Sugata. O Bhagavān, we will not destroy Jambudvipa again. We will not destroy flowers, fruits and crops again. "This region has become like a caitya - O Bhagavān, we will consider it like that. ${ }^{134}$ Wherever this Great King of Manuals will circulate, there this Vajra Beak dhāraṇi will circulate. O Bhagavān, we will always consider that place to be similar to a Tathāgata caitya. We will always provide protection, shelter and safeguard in that province, city, region, village, ${ }^{135}$ forest, hamlet, house or monastery. We will ward off all cold spells, winds, thunderbolts and untimely clouds. We will ripen all flowers, fruits and crops, [to be] soft-bodied, pleasing, fragrant, perfect and to have pungent ${ }^{136}$ juices. We will eliminate all discord, agitation, famine, harsh speech and bad omens. We will send down rain showers duly at the proper time. We will

134 On this phrase and its contexts, see Schopen (1975).

135 BHSD 170.

136 Tỉkșna does not appear to fit the context perfectly. 
maṇụūkatryambukamakṣikatrailāțakaśatapadabhramaraśukaśārikām api vārayiṣyāmaḥ | vināśayiṣyāmah | sarvetyupadravān praśamayiṣyāmaḥ | na ca bhagavan bhūyaḥ pāpadharmasamācāreṇa samācariṣyāmaḥ | sarvadurvṛștyanāvṛștim antardhāpayiṣyāmaḥ | śapathapratijñena bhagavan sthāsyāmaḥ | triratnān satataṃ bhagavan śikṣāsaṃvaraṃ paripālayiṣyāmaḥ | na ca bhūyo bhagavan jambudvīpakānāṃ sattvānāṃ vihețhayāmaḥ | yathā putravat paripālayiṣyāmaḥ | tathāgatavacanānujñātaṃ bhagavan paścime kāle paścime samaye sarvasattvān paripālayiṣyāmaḥ | saṃdhārayiṣyāmaḥ | svastikṣemasubhikṣaṃ sampādayiṣyāmah |

[5.5] atha khalu bhagavāṃs tān nāgarājān samāśvāsyaivam āha | evaṃ bhujagādhipate kariṣyatha | mā upekṣatha iti |

[5.6] athopacāravidhiṃ vyākhyāsyāmaḥ |

sarvakarmakaraṃ śubham |

ekavīra ayaṃ mantraḥ sarvakāryaṃ kariṣyati |

ekavelā smārayet prājñaḥ uccasthāne tu paṇḍitaḥ|

mahāśabdena svareṇa osmārayaḥ |

yatra yatraiva sthāne śabdaḥ śrūyate | tatra tatraiva sarvakālaṃ śîtavātameghāśanividyun nātikramiṣyanti | na ca śakyaṃ bhūyaḥ kenacid ojo 'pahartum | na ca hiṃsitum | pūrvāmukham uccasthāne parvate

2 vārayișyāmaḥ] DE; cārayișyāmah A, dhārayișyāmah BC • sarvetyupadravān] BCE; -vo A, -vā D - na ca] BCDE; na ra A <D60v> 3 bhagavan] BCDE; bhavan A • bhūyaḥ] BCDE; bhayah A • samācarișyāmaḥ] BCD; samācārayiṣyāmaḥ $\mathrm{AE}<\mathrm{C1020d>} \quad 4$-durvṛștyanāvṛșțim] $\mathrm{BCDE}$; -duvṛștānāvṛștim A • -payișyāmaḥ] BCDE; -payimah A <A77r • • sapatha-] BCDE; śayatha- A 5 -ratnān] BD; -ratnā ACE • śikṣā-] BE; sikhyā- ACD $\mathbf{6}$ sattvānāṃ] ABCpcDE; om. Cac <B39v> 7 -ānujñātaṃ] ACDE; -naṃ B 10 bhagavāṃs] ABE; -vās CD • tān] BCDE; mān A 11 bhujagādhipate] $\mathrm{BCD}$; bhujaṃgādhipati $\mathrm{A}$, bhujaṃgādhipate $\mathrm{E} \quad 12$ athopacāravidhiṃ] $<$ A77v $>13$-karma-] ABCpcDE; -karmakarma- Cac <D61r $>14$ kariṣyati] E continues after a gap at [5.6] 15 smārayet] BCD; -ya A • prājñaḥ] ACD; jñaḥ B 16 osmārayaḥ] BCD; ta smārayeḥ A 18 -vidyun] BCD; -yu A • -kramișyanti] BCD; -ati A <B40r> • ca śakyam] BCD; śa cakyam A • ojo] em.; oṣtto $\mathrm{ABC}$, oṣno D 19 himsitum] BC; om. A, vihimsitum D. A omits: na ca himsitum • pūrvā-] BCD; pūrva- A • uccasthāne] CD; -nai A, -na B 
ripen crops, flowers and fruits. We will ward off all stinging insects, mosquitos, locusts, creeping animals, frogs, flies, bees, horseflies, centipedes, bees, parrots and mynas. We will destroy them. We will eliminate all calamities and troubles. O Bhagavān, we will not act with acts of evil morality again. We will make all want of rain and drought disappear. O Bhagavān, we will abide by the promise [the breaking of] which results in a curse. O Bhagavān, we will always guard the Three Jewels and the vow of precepts. O Bhagavān, we will not harm beings in Jambudvīpa again. We will guard them as an own son. O Bhagavān, we will guard all beings as authorized by the teachings of the Tathāgata in the last time, in the last age. We will preserve them. We will produce success, safety and plenty."

[5.5] Then the Bhagavān, having encouraged those Nāga kings, said, "O Serpent chiefs, act like this, do not be indifferent.

[5.6] "Now I will teach the auspicious offering manual

Which can bring about any effect.

This mantra is a unique hero, it will do any task.

The wise and learned one should call it to mind only once in an elevated place. ${ }^{137}$

One should call it to mind in a loud voice and sound.

Wherever the words are heard, there no cold spells, winds, clouds, thunderbolts and lightning will ever pass. Nobody is able to take away the vital fluid or to cause harm again. The spell-master, clean, wearing clean and white clothes, ${ }^{138}$

137 Compare uccasthāna [1.13] [3.15] [5.6] with bhavanasara, uccasara [2.27], saranamūrdhan [1.13], uccaśarasi, ūrdhvasarasi [4.1] and uccaśaraṇa [6.7].

138 Note that the vidyādhara is not wearing robes (civvara) here as in [2.28] but pure clothes of white (sukla) colour. Does this imply that he may also be a layperson? Note that the common word used for white with regard to lay clothes is Sanskrit avadāta or odāta in Pali. 
vāraṇyāyatanagrāmavihāre vā yatra sthāna-m-uccataraṃ tatra vidyādhareṇa śucinā śucivastraśuklavāsasā caturasramaṇḍalakaṃ mṛdgomayasamanvitam kartavyam | hastapramāṇam śarapuñjakaṃ madhye maṇḍale nikhantavyam | ekaviṃśati vārān mantraṃ parijaptavyam | caturṣu mạ̣ḍalakoṇeṣu khadirakīlakam nikhantavyam | aṣțāṅgulapramāṇam ekaviṃśati vārān mantreṇa parijapya pañcaraṅgikasūtreṇa samantena trigụ̣itena veșțayitavyam | sapta japta dhūpakațacchakam sthāpya maṇḍalam dhūpayet | sarṣapā-mavakiretavyāḥ | ekaviṃśati vārān japtāḥ puṣpāvakīrṇaṃ ca kartavyam | catvāro ghațavalayo dātavyāḥ | caturdiśam madhyamạ̣ḍalake baliṃ sthāpayet | dadhikṣīraśarkaratạ̣ụulaguḍasarvasamyukta dātavyāḥ | caturdiśam sīmābandho dātavyaḥ | lājāsarṣapam ca pañcavārān mantram uccārayitavyam | pūrṇapañcadaśyāṃ prayoktavyam | uccasvareṇa paṭhitavyam | caturdiśam adha ūrdhva sarṣapāḥ kṣeptavyāḥ | sarvanāgānāṃ svena svena vārān niścārayitavyam | sahaprayuktamātrasyāsya vidhānasya sarvākālameghāśanidușțanāgā baddhā bhavișyanti | stambhitā bhavișyanti | sarvadurnimitta-ītyupadravopasargagrahabhūtapiśācayakṣarākṣasā dūratạ̣ parivarjayanti | samantād yojanaśatam sīmābandho bhavati | sarvavyādhayạ̣ sarvarogāḥ sarvaduștacittāḥ pratyarthikapratyamitrā na prabhavanti | sarvapuṣpaphalasasyāni supariniṣpannāni bhaviṣyanti | suparipaktāni surasāni bhaviṣyanti | sarvabījāni sukham saṃvardhitāni prarohanti | sarvakṛtyākarmaṇakākhordā vinaśyanti | yāvan noddhriyate tāvat sīmābandhaḥ

1 uccataraṃ] AD; uccātanaṃ $\mathrm{B}$, uccatara $\mathrm{C}$ • tatra] $\mathrm{BD}$; tratra $\mathrm{A}$, kutra $\mathrm{C} \mathbf{2}$ śucinā] $\mathrm{ABC}$; cinā D • -vastra-] BCD; -ram A • mṛdgomaya-] D; śṛgomaya- A, mṛngomaya- B, mṛomaya- C <A78r > 3 śara-] conj.; śaraṇaṃ ACpc, om. BCac, śaraṇa- D •-puñjakaṃ] B; -puñjākaṃ A, -pūjākaṃ C, -puñjaka D • madhye maṇdale] ABC; madhyamaṇḍalam D • nikhantavyam] CD; nikhattavyam A, likhantavyam B 4 vārān] BD; vārā AC • caturșu] BD; cacatuṣu A, catuṣu C $\mathbf{5}$-kīlakaṃ] BD; -kalaka A, -kîlaka C • -khantavyam] ABCDpc; -khavyamnnta Dac <D61v> 6 parijapya] BCD; parijapyavaṃ $\mathrm{A}<\mathrm{C} 1021 \mathrm{u}>\bullet$ trigunitena] $\mathrm{ABCpcD}$; om. Cac 7 -kațacchakaṃ] $\mathrm{BCD}$; -kacchakam A 7-8 -kiretavyāh] C; -kiratavyāh ABD 9 madhyamaṇdalake] BD; madhye maṇdualake AC • sthāpayet] <A78v> 10 -yukta] ACD; ++ B <B40v> • dātavyāḥ] ACD; -yā B 11 sīmābandho] BCD; sīmābadhyo $\mathrm{A}$ • dātavyaḥ] $\mathrm{AB}$; -yam $\mathrm{C}$, -yaṃh $\mathrm{D}$ • lājāsarșapaṃ ca] $\mathrm{BCD}$; lājāsarșa $\mathrm{A}$ 12 prayoktavyam] CD; -yaḥ AB 13 sarṣapāḥ] BCD; sașapā tu A • kṣeptavyāḥ] BCD; kṣeptatavyāḥ $\mathrm{A} \bullet$ sarvanāgānāṃ] $\mathrm{AD}$; -nā $\mathrm{BC} \bullet$ vārān] $\mathrm{ApcBC}$; rān $\mathrm{A} a c$, vārā $\mathrm{D} 14$ vidhānasya] em. Tib; midhānasye $\mathrm{A}$, nidhānasya $\mathrm{BCD}<\mathrm{D} 62 \mathrm{r}>15$ sarvākāla-] em.; kāla- A, sarvakāla- $\mathrm{BCD} \bullet$ -āśani-] ACD; -āśanaṃ B • baddhā] em.; bandhā ABC, badhnā D 16 -durnimitta] BCD; -duștanimitta A <A79r> 17 sarvavyādhayaḥ] BCD; -ye A 18 -dușțacittāḥ] D; -durșṭacitta A, -dușțacintā B, -duḥ̣țacittāḥ C • na] BCD; ma A 20 sukhaṃ] AD; sukha- B, mukhaṃ C • saṃvardhitāni] BD; saṃbandhitāni AC 21 -kākhordā] BC; -kārkhodā A, -kākhordāni D • vinaśyanti] $\mathrm{BC}$; nibhavișyanti $\mathrm{A}$, naśyanti $\mathrm{D}<\mathrm{B} 41 \mathrm{r}>$ • yāvan] $\mathrm{BCD}$; khāva Aac, vakhāva Apc • noddhriyate] $\mathrm{D}$; nodhiyate $\mathrm{A}$, nodhriyate $\mathrm{BC}$ 
should make a square mandalaka with cow dung, facing east at a high place, ${ }^{139}$ a mountain or forest, village or monastery, at an elevated place. A multitude of arrows $^{140}$ measuring a hasta ${ }^{141}$ should be driven into the ground in the middle of the mandala. The mantra should be recited twenty-one times. A stake made of khadira wood measuring eight angulas should be driven into the ground in the four corners of the mandala, and having enchanted them twenty-one times with the mantra, these should be encircled thrice all around with five-coloured twine. Having placed a ladle with frankincense enchanted seven times, one should fumigate the mandala. Mustard seeds should be scattered. Having enchanted them twenty-one times, flowers should be scattered. Four circles of pots should be offered. One should place an offering in the four directions and in the middle of the mandalaka. Curd, milk, candied sugar, rice grains and molasses joined together should be offered. A sealing of the boundaries should be performed in the four directions. The mantra should be recited into parched grains and mustard seeds five times. It should be employed on the fifteenth day of the waxing moon. It should be recited in a loud voice. Mustard seeds should be scattered in the four directions, downwards and upwards. It should be uttered ${ }^{142}$ for all Nāgas as many times as it is correlated. Merely upon employing that manual, all untimely clouds, thunderbolts and hostile Nāgas will be bound. They will be stopped. All bad omens, calamities, troubles, misfortunes, Grahas, Bhūtas, Piśācas, Yakșas and Rākṣasas are kept off from a distance. There will be a closing of the boundaries all around for a hundred yojanas. All diseases, all illnesses, all the evil-minded, all rivals and adversaries: these do not prevail. All flowers, fruits and crops will be well developed. They will be perfectly ripe and juicy. All seeds shoot forth easily developed. All Kṛtyā-sorcery and Kākhordas ${ }^{143}$

139 Compare uccasthāna [1.13] [3.15] [5.6] with bhavanasara, uccasara [2.27], śaranamūrdhan [1.13], uccaśarasi, ūrdhvasarasi [4.1] and uccaśaraṇa [6.7].

140 Compare śarapañcaka in [4.1].

141 Does this refer to the mandalaka? Cf. [2.24].

142 BHSD 306.

143 See Sanderson (2004: 290-92). 
kṛto bhaviṣyati | tāvat sarvanāgāḥ kālena kālaṃ varṣadhārā-m-utș̣janti | sarvapuṣpaphalasasyāni suparipūrṇā niṣpadyante | yatraiva kāryam bhavati sarvatra ekavelāyām anusmartavyā sidhyatīti | madhusikthamayo garuḍạ̣ kartavyaḥ | așțāṅgulapramāṇam paryan̉kaniṣaṇno vikasitapakṣạ̣ | nāgarājāsanaḥ | navaśīișakaṃ makuṭāvabaddhabhujagam | dakṣiṇahastena triśīrṣakaṃ vāmahastena maṇiratnaparigṛhīta jvalitasuvarṇena cchādayitavyam | rañgena yathāvidhi spṛsitavyam | vicitravastreṇopari sthāpyāhorātraṃ sahasravārān mantra utsārayitavyaḥ | yady api kāya-utsāho na bhavati tadā śuklabhojanam bhoktavyam | punạ̣ snānam kartavyam evaṃ sādhayitavyam | gugguludhūpo dātavyam | yathāvibhavataḥ puṣpadhūpabalir dātavyāḥ | dīpaḥ prajvālayitavyaḥ | tasyaivāgrataḥ sthāpayitavyaḥ | darśanaṃ dāsyati | samākhyāti sarvavareṇa pradhārayati | sarvakarma karoti | yam ājñāpayati tạ̣ karoti | nirākulena guhyasthāne dhārayitavyam | yadā anāvṛșțikāle tadā vidyādhareṇa g̣̣hya nāgabhavanaṃ netavyam | nāgabhavanasare sthāpya dhūpaṃ dattvā trīṇi vārān mantraṃ japatā sarṣapaṃ bhavanamadhye okiratavyam | sadyaḥ sarvanāgā varṣadhārā-m-utsṛjanti | yadi sadyo na varṣanti tato nāgabhavanaṃ samantato garuḍāpūrṇaṃ paśyanti | ekajvālī bhaviṣyanti | taptavālukā mūrdhni śirasi patiṣyanti | jalaśoṣaś ca bhavati | ativṛ̣̦țau abhrābhimukhaṃ darśayati varṣam upatișthati | sarveṣu vātāśaniśītavarṣavalāhakānāṃ darśayitavyam | kṣaṇena upatișṭhati | saptayojanārdhena samantato caturdiśam aśanir na patati | na ca śītakālavāyụ̣

1 bhaviṣyati] ACD; -anti B • sarvanāgāḥ] BCD; -ān A • varṣadhārā] ApcBCD; varṣarā Aac 2 nișpadyante] BCD; nipayante $\mathrm{A}\langle\mathrm{A} 79 \mathrm{v}\rangle\langle\mathrm{D} 62 \mathrm{v}\rangle \mathbf{3}$ anusmartavyā] A; -vyāḥ BCD • sidhyatīit] ACD; siddhetīti B - madhusikthamayo] C; madhuśicchānayor A, madhusikthamayayor B, madhusikthamayī D $\quad \mathbf{5}$-āvabaddhabhujagam] BCD; -āvardhabhujamga A $\mathbf{6}$ jvalita-] ABC; jvalitata- D • -suvarṇena] corr.; -suvarṇatta A, -suvarṇana BCD • cchādayitavyam] BCD; cchāvāyitavyam A $\quad$ 7-9 A omits: raṅgena yathāvidhi spṛsitavyam | vicitravastreṇopari sthāpyāhorātraṃ sahasravārān mantra utsārayitavyạ̣ | yady api kāya-utsāho na bhavati tadā śuklabhojana bhoktavyam | 7 sthāpyāhorātraṃ] <C1023d> 8 utsārayitavyaḥ] CD; om. A, -yam B 9 snānaṃ] BC; snātraṃ AD 10 guggulu-] corr.; gugulu- ABCD • -vibhavatah] ACD; +++ta B $<$ B41v $>$ • puṣpadhūpabalir] BD; -bali AC 11 prajvālayitavyaḥ] BCD; -yam A • tasyaivāgratah] $\mathrm{BD}$; tasaivāgrataḥ $\mathrm{AC} \bullet$ sthāpayitavyaḥ] $\mathrm{D}$; -vyāḥ $\mathrm{ABC}<\mathrm{D} 63 \mathrm{r}>\bullet$ dāsyati] $\mathrm{ABC}$; -anti $\mathrm{D}<\mathrm{A} 80 \mathrm{r}>$ 12 pradhārayati] $\mathrm{BCD}$; dhārayati $\mathrm{A}$. Ms $\mathrm{E}$ continues here after a gap with $<\mathrm{E} 63(22) \mathrm{r}>$ • àjñāpayati] AC; ājñāyati B, ājñāpati DE $12-13$ taṃ karoti] BCDE; om. A 13 -yitavyam] BC; -yatavyam ADE 14 gṛhya-] ABDE; gṛhva- C • netavyam / nāgabhavana-] ABCDpcE; om. Dac 15 vārān] $\mathrm{BC}$; vān $\mathrm{ADE} \bullet$ mantraṃ] $\mathrm{BDE}$; mantra $\mathrm{AC} \bullet$ sarṣapaṃ] $\mathrm{ADE}$; -pa $\mathrm{BC} 16$ okiratavyam] $\mathrm{BCD}$; okitatavyam $\mathrm{AE}$ • varșanti] $\mathrm{BCDE}$; -ati $\mathrm{A} \quad 17$ garuḍapūrṇaṃ] $\mathrm{CD}$; garuḍapūrṇa $\mathrm{AE}$, garuḍapūrṇam B • paśyanti] ACDE; -ati B 18 mūrdhni] CDE; mūdhi A, mūrdhi B • patișyanti] BCDE; pavișyanti A • jalaśoșaś] ABCE; laśoșaś D - bhavati] BCDE; -anti A <A80v> 19 abhrābhi-] BDE; abhrā- A, abhrāti- C 20 -šitavarșa-] BCDE; -śīta- A <B42r> • -tișṭhati] ABCE; -tișțhatisi D <D63v> 21 -yojanārdhena] ABCE; -yonārdhena D 
will perish. Until it is driven out, the sealing of the boundary will be made. Until then all Nāgas send down rain showers duly at the proper time. All flowers, fruits and crops ripen perfectly. Where there is a task, it should be called to mind everywhere only once and it succeeds. A wax Garuḍa should be made. ${ }^{144}$ It should be eight angulas by measure, seated cross-legged, with the wings opened. It should be seated on a Nāga king. The serpent is nine-headed and crowned. [The Garuḍa] should hold a three-headed [Nāga] in the right hand, and jewels and gems in the left. It should be covered with shining gold. It should be touched by colours according to the ritual manual. Having placed it at a high place [covered] with cloths of various kinds [and colours], the mantra should be recited day and night a thousand times. If there is no body-energy, one should take white foods. ${ }^{145}$ Besides one should bathe and it should be thus [continued to be] practised. Bdellium incense should be offered. An offering of flowers and incense should be offered according to one's wealth. A lamp should be lit. These should be placed in front of that. It will appear. It tells [everything] and remembers [to bestow] all boons. It executes all tasks. What is commanded, it does that. It should be kept in a little-frequented, secret place. If there is a drought, then the spell-master should seize it and take it to the residence of the Nāgas. Having placed it at the Nāga residence lake, and offered incense, mustard seeds should be thrown into the middle of the residence after reciting the mantra three times [into each seed]. On the same day all Nāgas send down rain showers. If they do not send rain on the same day, then they see the Nāga residence full of Garudas all around. They will become a single flame. Hot sand will fall on their heads and skulls. The water will dry up. If there is too much rain, he shows $i^{146}$ towards the clouds and stops the rain. It should be shown towards all winds, thunderbolts, cold spells and rainclouds. It stops these in a moment. Thunderbolts do not fall

144 See [4.1] for a wax Nāga figure.

145 It is unclear if the person should fast or if he is on a diet of white foods for this ritual.

146 I.e. the statue. 
bhūyah prabhavișyanti | sarve stambhitā bhavanti | vāyusaṃkṣobhe catuḥpatheșu sthāpayitavyaḥ | athavā nagaradvāre kṣaṇenāpi sarvavāyavạ̣ stambhitā bhavanti | vairambhavāyur api stambhito bhavati | baddhāś ca bhavanti | na ca śakyaṃ bhūyo pravāhayitum | sahadarśanamātreṇa sarve nāgāḥ palāyiṣyanti |

[5.7] sarvagaruḍahṛdayapaṭhitasiddhaparamasiddhavajratuṇ̣̣ā nāma dhāraṇī samāptā|

1 vāyusaṃkṣobhe] ACE; -bho B, -bhya D 2 -patheșu] conj. Tib; -parvateșu ABCDE 3 stambhitā] $\mathrm{BCDE}$; tambhitā A - vairambhavāyur] $\mathrm{BDE}$; vairambhavanti $\mathrm{A}$, vairaḥvyayur $\mathrm{Cac}$, vairahbhavyayur $\mathrm{Cpc} \bullet \mathrm{A}$ omits: api stambhito bhavati $\bullet$ stambhito] BDE; om. A, cumbhito C • baddhāś] corr.; gandhāś ABCE, badhāś D 4 śakyaṃ] BDE; sakṛd AC • sahadarśanamātreṇa] $<\mathrm{C} 1024 \mathrm{u}>\quad 5$ palāyiṣyanti] AE; prapalāyayișyanti B, +++++ C, pravalāyiṣyanti D. C illegible: namātreṇa sarve nāgā palāyiṣyanti $\quad \mathbf{6}$ sarva-] A; sarvaka- $\mathrm{BCDE}<\mathrm{A} 81 \mathrm{r}>\quad$ • $\quad$-siddha- $\left.{ }^{1}\right] \mathrm{AC}$; -siddhā- BDE • -siddha- $\left.{ }^{2}\right]$ ACD; -siddhā- BE 7 samāptā] E; -tạ̣ ABCD 
for seven and a half yojanas all around in the four directions. Cold spells and untimely winds do not prevail again. All are stopped. When there is a disturbance by winds, it should be placed at crossroads ${ }^{147}$ or at the city gate. All winds are stopped in a moment. Even the Vairambha ${ }^{148}$ winds are stopped. They are bound and unable to blow again. Merely upon showing, all Nāgas will run away."

[5.7] The Vajra Beak Dhāraṇi, the Heart of all Garuḍas, Effective upon Recitation, the most Effective One has ended. ${ }^{149}$

147 Cf. Saṃvarodayatantra 21.16: catuḥpathe puradvāre rājadvāre mațhe 'pi vā. 148 BHSD 511: "name or epithet of certain very violent winds" and "name of an ocean." 149 Note that in the Tibetan version there is no indication of a chapter ending here. 
[6.1] atha brahmaviṣnumaheśvarāś catvāraś ca mahārājā yena bhagavāṃs tenopasaṃkrāntā upasaṃkramya bhagavantaṃ tripradakṣinịkṛtya bhagavantam etad avocat | vayam api bhagavan sarve sāmagrībhūtā jvalitavajrāśanituṇ̣ā nāma dhāraṇị̣ bhāṣiṣyāmaḥ | sarvanāgānāṃ hṛdayahāriṇịm hṛdayaśoṣaṇị̣ dușțanāgakulotsādanīm sarvavātameghāśaninivāraṇị̣̄ sarvasasyapuṣpaphalaniṣpādanīṃ dāsyāmaḥ | tad bhagavān adhitișthatu | sarvasattvānāṃ arthāya |

[6.2] atha bhagavān brahmāviṣnumaheśvarāṃś catvāraś ca mahārājān evam āha | bhāṣadhvaṃ kulaputrā bho adhișthitaṃ mayā sarvasattvānām arthāya hitāya sukhāya |

[6.3] atha brahmāviṣṇumaheśvarāś catvāraś ca mahārājā-n-imāṃ dhāraṇīm bhāșante sma |

namo ratnatrayāya | namo bhagavate śākyamunaye tathāgatāyārhate samyaksambuddhāya | namaś caṇḍavajrapāṇaye | namaś caṇḍavajradharāya mahābalaparākramāya | namas trailokyamūrtaye | namaḥ caturṇāṃ mahārājānām | namo vajrāśanijvalitaraudrāțtahāsāya | matha matha pramatha pramatha | jvalitavikṛtavaktra | jaya jaya | mahābalavīryaparākrama | krodharāja | brahme | subrahme | brahmasvare | bho bho nāgādhipate | visara visara | mā te

1 brahma-] AC; brahmā- BDE • -rāś] ACDE; -raś B • catvāraś ca] BDE; catvāro A, ca C 1-2 C illegible: yena bhagavāṃs tenopasaṃkrāntā upasaṃkramya bhagavantaṃ $\mathbf{1}$ yena] BDE; yaita A, ++ C 2 -krāntā upasaṃkramya bhagavantaṃ] E; -kramya A, ++++saṃkramya bhagavataṃ B, ++ C, -krāntā upasaṃkramya bhagavatas D • tri-] BDE; stri- AC • -kṛtya] BCD; -kṛto A, -kṛ E $<$ D64r $>3$ etad] ABpcCDE; eta Bac <E63(22)v $>$ avocat] ABCD; avoca E 4 nāma] DE; nāga$\mathrm{ABC}<\mathrm{B} 42 \mathrm{v}>$ • bhāṣișyāmaḥ] BCD; bhāṣitāmiḥ A, bhāṣitāmaḥ E $\mathbf{5}$ hṛdayahāriṇịm] corr.; -iṇi ABCDE • hṛdayaśoṣaṇịm] B; -ṇi ACDE • -kulotsādanīṃ] D; -krūrocchādanī A, -kulotsādanī BCE 6 -ṇīm] B; -ṇi ACDE • -sasya-] BCDE; -syāsa- Aac, -sasyā- Apc • niṣpādanīṃ] D; niṣpādanī ABC, niṣādanī $\mathrm{E} 7$ bhagavān] $\mathrm{BC}$; -vānn $\mathrm{AE}$, -van $\mathrm{D} \bullet$ adhitișthatu] $\mathrm{BCD}$; -antu $\mathrm{AE}<\mathrm{A} 81 \mathrm{v}>\bullet$ arthāya] $\mathrm{BDE}$; mathayi AC $\mathbf{8}$-maheśvarāṃś] D; -maheśvarāṇaś $\mathrm{AE}$, -maheśvaroś $\mathrm{B}$, -maheśvarāś $\mathrm{C}$ • mahārājān] BCD; mahārān AE 9 bhāṣadhvaṃ] ACDE; bhāṣasva B • kulaputrā] CDE; -putro A, -putra B 10 sukhāya] BCD; -ye AE 11 brahmā-] ABCD; brā- E • -maheśvarāś] BD; -rāḥś A, -rāṃś CE • mahārājā-n-imāṃ] ACDE; mahārājānn imāṃ B • dhāraṇịm] CD; dhāramī A, dhāraṇī $\mathrm{BE} 12$ bhāṣante] $\mathrm{ABCDEp} c$; bhāṣate Eac 13 śākyamunaye] $\mathrm{BCE}$; -ya $\mathrm{AD} 14$ caṇụavajrapāṇaye] $\mathrm{BCE}$; -ya $\mathrm{AD}\langle\mathrm{D} 64 \mathrm{v}\rangle \quad$ - $\quad$-dharāya] $\mathrm{ABCD} p c \mathrm{E}$; -rāya Dac 15 namạ̣] $\mathrm{AE}$; nama $\mathrm{BCD}$ 16 mahārājānām] $<\mathrm{A} 82 \mathrm{r}>\bullet$-hāsāya] $\mathrm{BCDE}$; -hāya A 17 pramatha] $<\mathrm{B} 43 \mathrm{r}>\bullet$ jaya jaya] $\mathrm{BD}$; jaye jaye $\mathrm{AE}$, -viyajaye $\mathrm{C} \bullet$-parākrama] $\mathrm{A}$; -mah $\mathrm{BCDE} \bullet$ krodharāja] $\mathrm{ADE}$; -jah $\mathrm{BC} 18$ nāgādhipate] $\mathrm{A} p c \mathrm{BCDE}$; nādhipate $\mathrm{A} a c \bullet$ visara visara] $\mathrm{BCD}$; visarata visarata $\mathrm{AE}$ 
[6.1] Then Brahmā, Viṣnu, Maheśvara and the Four Great Kings approached the Bhagavān and having approached him circumambulated him three times and addressed the Bhagavān, "O Bhagavān, we too, all assembled, will utter the dhāraṇi called Blazing Vajra Thunderbolt Beak. We will offer this seizer of the heart of all Nāgas, drier of their heart, destroyer of the families of harmful Nāgas, remover of all winds, clouds and thunderbolts, and ripener of all crops, flowers and fruits. May the Bhagavān give his empowerment for the benefit of all beings."

[6.2] Then the Bhagavān addressed Brahmā, Viṣnu, Maheśvara and the Four Great Kings, "Speak, O sons of good family, listen, I have given my empowerment for the benefit, welfare and comfort of all beings."

[6.3] Then Brahmā, Viṣnu, Maheśvara and the Four Great Kings ${ }^{150}$ uttered this dhāraṇi,

"Veneration to the Three Jewels. Veneration to the glorious Säkyamuni, the Tathāgata, Arhat and Perfectly Awakened One. Veneration to Candavajrapāni. Veneration to Candavajradhara of Great Strength and Courage. Veneration to the Embodier of the Three Worlds. Veneration to the Four Great Kings. Veneration to the One with a Fierce and Loud Laughter that Blazes like a Vajra Thunderbolt. Stir, stir, destroy, destroy, $O$ the One with a Blazing Transformed Face, be victorious, be victorious. $O$ the One of Great Strength, Heroism and Courage. $O$ Wrathful King. $O$

150 The reading -mahārājān is likely to have erroneously followed the one in the previous paragraph as "n" does not look like a hiatus-bridger here. 
brahmadạ̣ḍena mūrdhānaṃ sphoțayāma hūṃ hūṃ phaṭ | bhara bhara viṣnucakrahastam | bho pannagendra mātikrama | mā te viṣṇucakreṇa śirasi cchindāmi | bhūṭali bhūṭali bhūṭali bhūṭali bhūṭali || 5 || hūṃ hūṃ phaṭ | muhu muhu muhyantu sarvadușțanāgān sphoțaya hṛdayam | maheśvarajvalitatriśūladhara hana hana hūṃ hūṃ phạ̣ | muci muci | tuṭi tuṭi | bhara bhara | kṣaṇi caturṇām mahārājānāṃ jvalitaśakti | dhara dhara hūm phaṭ | sphura sphura | visphura visphura | carca carca | nāśaya duṣțanāgahṛdayāni | sphoțaya hūṃ hūm phaṭ | saṃhara saṃhara | duṣṭāśanivātameghaśītavātavidyujjvālāṃ bhasmīṃkuru hūm hūṃ phaṭ phat svāhā | samayam anusmara | bho pannagādhipataye | viṣnumūrtaye | bho bho tuṭi tuṭi hūm hūṃ phat phaṭ svāhā | vajrāśanināśāya hūṃ phaṭ svāhā | sarvanāgahṛdayāni sphoțakāya hūṃ phaṭ svāhā | buddhavilokitāya svāhā | brahmāya svāhā | viṣnumūrtaye svāhā | maheśvarajvalitatriśūlāya svāhā | caturmahārājasamayadharāya svāhā | bhujagāya svāhā | bhujagādhipataye svāhā | oṃ dhiri dhiri svāhā | jvalitavajrāya svāhā | romaharṣanāya svāhā | stuṭi suṭi | putreți svāhā | phaṭ phaṭ phaṭ phaṭ phaṭ || 5 ||

[6.4] atha samanantarabhāṣitā jvalitavajrāśanituṇ̣ā nāma dhāraṇī sarvaduṣṭanāgāḥ klinnadurgandhakāyāḥ saṃsthitāḥ | ślathaślathacitrakāyāḥ

1 -daṇdena] DE; -kaṇḍana AC, -daṇḍana B • sphoțayāma] BDE; -yāta AC • bhara bhara] BDE; bhava bhava A, bhara $++\mathrm{C}<\mathrm{C} 1022 \mathrm{~d}\rangle$ 2-3 C illegible: viṣnucakrahastam bho pannagrendra mātikrama mā te viṣnucakreṇa śirasi cchindāmi bhūṭali bhūṭali bhūḍali bhūọali bhūṭali 2 -hastam] ABD; ++ C, -hatam E • mā te] BDE; mā tre A, ++C • śirasi] BDE; śirisi A, +++ C 3 cchindāmi] BDE; -āni A, ++ C • bhūțali bhūṭali bhūțali bhūṭali bhūṭali] E; bhūtalindrațali bhusi A, bhūṭali bhūṭali bhūọali bhūụali bhūṭali ++++++++++++ C, bhūṭali D • || 5 ||] ACDE; om. B 3-4 muhu muhu] ACDE; muhu mu B 4 sarvadușțanāgān] B; -nāgā ACDE • sphoțaya] BCD; -ye AE <E64(71)r> 5 -dhara] $\mathrm{BDE}$; -dharā AC • C illegible: hana hana hūṃ hūṃ phaṭ <A82v> 6 hūṃ] ACDE; hūṃ hūṃ B 7 visphura ${ }^{2}$ ] $<$ D65r $>8$ sphoțaya] BCD; -ye AE • saṃhara saṃhara] $\mathrm{BD} p c \mathrm{E}$; saṃhana saṃhana $\mathrm{AC}$, saṃraha saṃraha Dac $\mathbf{9}$-vidyujjvālāṃ] E; -vidyutkālaṃ A, -vidyujjvālā BD, -vidyulkālā C • bhasmīṃkuru] ACD; ++++ B, bhasmīkuru E • phaṭ phaț] ABCE; phaț D 10 -pataye] ACE; -pate BD 11 phaṭ phaț] ABCE; phaṭ D • vajrāśani-] DE; vajrāśanī- AC; ++śani- B <B43v> • -nās̄āya] em.; -nāśaye A, -nāśaya BCDE 11-12 C illegible: hā | sarvanāgahṛdayāni sphoțakāya 12 sphoțakāya] BDE; -kāye A, ++ C 13 svāhāê] <A83r> 14 -samaya-] em. Tib; -sama- ABCDE • bhujagāya] BCD; bhujamgāya AE • bhujagādhipataye] $\mathrm{BD}$; bhujamgādhipataye $\mathrm{AE},+++++$ taye $\mathrm{C} 16$ suṭi] $\mathrm{ABCD} p c \mathrm{E} ;$ om. Dac • phat phat phaṭ phat phaț] ABCE; phaț D • || 5 ||] ACDE; om. B 17 samanantara-] BCDE; samantara- A 17-18 C illegible: tuṇ̣ā nāma dhāraṇi sarvadușțanāgāḥ <D65v> 18 sarvadușțanāgāḥ] ADE; -nāgāṃ $\mathrm{B}$, ++ C • ślathaślathacitrakāyāḥ] ABDE; +++++++++ C 
Brahmā. O Subrahmā. O Brahma-sound. Listen, listen, O Nāga Chief. Spread, spread. May we not make your head burst by Brahma-punishment, ${ }^{151}$ hūm hüm phaț. Provide, provide a hand with Viṣnu's discus. O Serpent chief, do not neglect, may I not cut your head with Viṣnu's discus, O Bhūtalī, O Bhūtalī, O Bhūtalì, O Bhūtalī, O Bhūtalī. Hūm hūṃ phaț. Bewilder, bewilder, stupefy all harmful Nāgas, burst their heart. O Bearer of Maheśvara's Blazing Trident. Kill, kill, hūm hūm phaț. Muci, muci, tuți tuți, provide, provide, hurt ${ }^{152}$ O Blazing Power of the Four Great Kings. Hold, hold, hūm phaț. Shine, shine. Sparkle, sparkle. Injure, injure, destroy the heart of harmful Nāgas. Burst, hūm hūm phaț. Destroy, destroy. Reduce harmful thunderbolts, winds, clouds, cold spells, gales and the blaze of lightning to ashes, hūm hūm phat phat svāhā. Keep the vow. Listen $O$ Serpent chiefs. O Embodiers of Viṣnu. Listen, listen, tuṭi tuṭi hūm hūm phaț phaț svāhā. Svāhā to the Vajrathunderbolt destroyer, hūm phaț. Svāhā to the One who Bursts the Heart of all Nāgas, hūm phaț. Svāhā to the One Beheld by the Buddha. Svāhā to Brahmā. Svāhā to the Embodier of Viṣnu. Svāhā to Maheśvara's Blazing Trident. Svāhā to the One who Keeps the Vow ${ }^{153}$ of the Four Great Kings. Svāhā to the Serpent. Svāhā to the Serpent chief. Om dhiri dhiri svāhā. Svāhā to the One with a Blazing Vajra. Svāhā to the One with the Bristling of the Hair. Stuṭi suṭi putreți svāhā. Phaț phaț phat phat phaț."

[6.4] Immediately after the dhāraṇi called Blazing Vajra Thunderbolt Beak had been uttered, the bodies of all harmful Nāgas became stinking and foul-smelling. Their bodies became very weak and spotted [with leprosy], and falling at the feet

151 Note that brahmadaṇda appears three times in the Mahāmāyūrĩ: brahmadaṇdatejohatam viṣaṃ, svasti sarvapreșakātaḥ, kālarātrītaḥ, kālapāśātaḥ, mṛtyudaṇ̣āạ̣, brahmadaṇ̣̂̄taḥ, iṇụradaṇḍātah (...) and brahmadaṇḍah parvatarājā.

152 Kșaṇi may also have once been given twice in the Sanskrit.

153 Cf. Amoghapāśakalparāja 10b: oṃ dușțasatvavibodhani samasamayadhare svāhā. 
sambhūtā bhagavataḥ pādayor nipatyaivam āhụ̣ | trāyatu bhagavan jugupsitā vayaṃ bhagavan sadevakena nașțā vayaṃ bhagavan na bhūyo bhagavan jambudvīpe sattvān vihețhayiṣyāmaḥ | na ca vihiṃsayiṣyāmaḥ | antaśaḥ prekṣitam api na prekṣiṣyāmaḥ | kị̣ punar avatāram iti |

[6.5] athāsyopacāro bhavati | sahasmaraṇamātreṇa anayā sarvanāgānāṃ śarīram khaṇ̣akhaṇḍam višīryante | klinnakāyā durgandhipūtino bhavanti | sarṣapam ekaviṃśati vārān parijapya caturdiśaṃ kṣeptavyam | sarvanāgā baddhā bhaviṣyanti | saptayojanaṃ samantena sīmābandho bhaviṣyati | vajram aștottaraśata vārān parijapya nāgā vārayitavyāḥ | ekavelā smārya sarvavātameghāśaniṃ nivāryeta | sarve vinaśyanti | sahasmaraṇamātreṇa sarvāśanayaḥ kṣaṇād vinaśyanti | yadi vajrāśanir bhavati muhūrtamātreṇa udakaṃ pravartayiṣyati | aśanikāle vajraṃ bhrāmayitavyam | yatra diśi bhrāmayati tatra diśi aśaniḥ krāmayati | sarvāśanayaḥ patanti | pratyūṣe rahogatah pratisaṃlīnaḥ paryañkamudrāṃ badhvāyaṃ mantro dvātriṃśad vārān smārayitavyaḥ | sahapravartitamātreṇa sarve vātameghāśanayo vinaśyanti | sarvadușțanāgā vinaśyanti | na prabhavanti | sarșapaṃ caturdikṣu kṣeptavyam | samvatsaraṃ sīmābandhạ̣ kṛto bhavati | sarvavātameghāśanayo baddhā bhaviṣyanti | sarvanāgā vaśyā bhaviṣyanti | saputrapautrāḥ saparṣadaḥ satatasamitaṃ sadānubaddhā bhaviṣyanti | sarvakarmakaro bhaviṣyanti |

1 trāyatu] BD; -antu ACE • bhagavan] A; -vān BCDE • jugupsitā] BDE; -tāḥ AC 2 vayaṃị $\mathrm{ABCE}$; yaṃ $\mathrm{D}<\mathrm{A} 83 \mathrm{v}>\bullet$ sadevakena] B; -nā ADE, + C • bhūyo] BDE; bhūyāh A, ++ C. C illegible: vayam bhagavan sadevakena nașțā vayaṃ bhagavan na bhūyo <C1023u $>\quad 3$ jambudvīpe] ABCD; dvīpya E • -yiṣyāmaḥ] ABCDpcE; -yitașyāmaḥ Dac • vihimssayiṣyāmaḥ] C; vahișyāmahe A, vihimasayișyāmahe $\mathrm{BD}$, vahisayișyāmahe $\mathrm{E} \quad$ - antaśaḥ] $\mathrm{BCDE}$; anantaśah A <B44r> 5 athāsyopacāro] $\mathrm{BD}$; atha sopacāro $\mathrm{ACE} \bullet$-mātreṇa] $\mathrm{BCD}$; -mātre $\mathrm{AE} \bullet$ anayā] $\mathrm{ABDE}$; punaryā $\mathrm{C}<\mathrm{E} 64(71) \mathrm{v}>\quad \mathbf{6}$ bhavanti] BDE; bhavati AC 7 ekavimśati] DE; evimśati AC, ekavimuśa $\mathrm{B}$ 8 -bandho] BCDE; -bandhe A • bhavișyati] D; -anti ABCE 9 -śata] ABpcCDE; -śaśata Bac • vārān] BCDE; vāvārān A <A84r • • vārayitavyāḥ] ACDE; +rayitavyāḥ B <D66r> 10 nivāryeta] C; nivāryanme $\mathrm{A}$, nivāryete $\mathrm{B}$, nivāryate $\mathrm{D}$, nivāryante $\mathrm{E} \bullet$-smaraṇa-] $\mathrm{BDE}$; -smara- $\mathrm{AC} 11$ kṣaṇād] $\mathrm{BCDE}$; -ān A • yadi] BCDE; yani A • bhavati] ApcBCDE; bhavavati Aac • muhūrta-] BCD; muhūtra- AE 12 pravartayișyati] ACDE; -anti B 13 bhrāmayati] $\mathrm{BCD}$; kramayati $\mathrm{AE} \bullet$ tatra] BCDE; tatah A • krāmayati] BCDE; krāmā A 14 pratisaṃlīnah] $<$ B44v $>\bullet$ mantro] BCE; -trau AD 15 smārayitavyaḥ] D; -vyam ABCE • vātameghāśanayo] ADE; -iyo $\mathrm{BC}<\mathrm{A} 84 \mathrm{~V}>16$ sarṣapam] $\mathrm{CDE}$; -pa $\mathrm{AB} \quad$ - caturdikșu] BDE; catudikșa A, catudikșaṃ C 17 samvatsaram] ADE; sarvānsaram B, savatsaraṃ C 18 sarvanāgā] ABDE; ++++ C • bhavișyanti²] BDE; -ati AC • saparșadaḥ] ACDE; sapārșadaḥ B <D66v $>19$ satatasamitaṃ] ACDE; sametasamitam B • -baddhā] BCDE; -buddhā A 
of the Bhagavān they said, “O Bhagavān, save us. O Bhagavān, we are detested by [the world] together with its Devas. O Bhagavān, we are destroyed. O Bhagavān, we will not harm beings in Jambudvīpa again. We will not hurt them. Furthermore, we will not even throw a [hostile] look. How much more [to mention] a descent. ${ }^{154}$

[6.5] "Now its offering follows. Merely upon calling it to mind, the bodies of all Nāgas fall to pieces. Their bodies become stinking, foul-smelling and putrid. Having enchanted mustard seeds twenty-one times, these should be scattered in the four directions. All Nāgas will be bound. There will be a closing of the boundaries for seven yojanas all around. Having enchanted a vajra 108 times, the Nāgas should be warded off. Having called it to mind only once, one can ward off all winds, clouds and thunderbolts. All are destroyed. Merely upon calling it to mind, all thunderbolts are destroyed in a moment. If there are vajrathunderbolts, water will come forth merely in an instant. ${ }^{155}$ At the time of thunderbolts the vajra should be moved around. Whichever direction it is moved, thunderbolts proceed there. All thunderbolts fall. At dawn being alone in privacy, having made the cross-legged gesture, this mantra should be called to mind thirty-two times. Merely upon reciting, all winds, clouds and thunderbolts are destroyed. All harmful Nāgas are destroyed. They do not prevail. Mustard seeds should be scattered in the four directions. The sealing of the boundaries is made for a year. All winds, clouds and thunderbolts will be bound. All Nāgas will be subdued. They will always follow constantly ${ }^{156}$ along with their sons, grandsons and retinues. They will perform all tasks. Having enchanted a pot ${ }^{157}$

154 Here and in the next section Nāgas appear to roam above in the skies and descend (when causing harm) or fall (when punished) from there.

155 Cf. [4.1].

156 Cf. Mahāpratisarā [51]: nityānubaddhā.

157 Note that the Tibetan version reflects a variation between "jars" and "bells" ghața and ghanțā in Sanskrit. Cf. [1.10] and the next footnote. 
ghațam ekaviṃśati vārān parijapyāśanikāle vā dātavyam | sarvadușțanāgānāṃ mūrdhā sphuṭati | ākāsaā bhūmitale bhavanti | iyaṃ dhāraṇi sarvatrāpratihatā |

[6.6] atha bhagavān mahāgaruḍendrabrahmavișṇumaheśvarāṃś ca sādhukāram adāt | sādhu sādhu mahābrahma subhāṣitā iyaṃ vāg udāhṛtā mahāvidyā iyaṃ dhāraṇīmantrapadā jambudvīpe sthāpitā | sarvasattvānāṃ hitasukhārtham | duștanāgānām akṛpānām akāruṇyahiṃsakānāṃ damanārthāya | nigrahārthāya | paradaṇḍakarmānupradānāya |

\section{[6.7] atha sāgaro nāgarājā}

samantākāraparikaracchatrākaranāgarājapramukhair atipremataijaskamaharddhikamahānāgarājair anyaiś ca koṭiniyutaśatasahasrair 10 dușṭanāgaiḥ sārdhaṃ yena bhagavāṃs tenopasaṃkrāmad upasaṃkramya bhagavataḥ pādau śirasābhivandya bhagavantam etad avocat | vayaṃ bhagavan mahatī nāgaparṣat saṃnipatitā | saparṣatsaparivārāḥ sarve sāmagrībhāvena paścime kāle paścime samaye sarvajambudvīpakānāṃ sattvānāṃ sarvapuṣpaphalasasyapatrapalāśān rakṣiṣyāmaḥ | sarvavātāśaniśītoṣnāni nivārayiṣyāmaḥ | kālena kālaṃ varșadhārā-m-utsṭjāmaḥ | tṛ̣agulmoṣadhisasyān virohayāmaḥ | svaśapathapratijñayā tathāgatasamayam

1 ghațam ekaviṃśati] $\mathrm{ABCD} p c \mathrm{E}$; ghațakaviṃśati Dac • dātavyam] B; -vyā ADE, -vyāḥ C 2 mūrdhā] em.; mūdhī A, tāṃ mūrdhān B, taṃ mūrdhā C, tāṃ mūrdhnā DE • sphuțati] C; sphuțiti AE, sphoțayati B, sphuțuti D <C1030d> • ākāśā] BDE; ādāśā A, +++ C 3 C illegible: vān mahāgaruḍendrabrahmaviṣnumaheśvarāṃś ca - bhagavān] BE; bhagan ADac, bhaga+ $\mathrm{C}$, bhagavan $\mathrm{D} p c \bullet$-brahma-] AD; -brahmā- $\mathrm{BE},++\mathrm{C}<\mathrm{A} 85 \mathrm{r}>\bullet$-maheśvarāṃś ca] E; -maheśvarāś ca $A B D,+++++C$ <E68(27)r> 4 mahābrahma] BCD; mahādrāṇa A, mahābrāhmaṇa E 4-5 C illegible: subhāṣitā iyaṃ vāg udāhṛtā mahāvidyā iyam dhāraṇimantra- 4 subhāṣitā] BE; subhāṣitāni A, ++++ C, subhāṣita D • udāhṛtā] BD; udāhṛtāna AE, ++++ C <B45r> 7 damanārthāya] $\mathrm{BCD}$; damanārthāye $\mathrm{AE} \bullet$ nigrahārthāya] BCD; -ye AE 10 -premataijaska-] $\mathrm{CDE}$; -prematraijaska- A, -premataijasā- $\mathrm{B}\langle\mathrm{D} 67 \mathrm{r}\rangle$ • anyaiś] ABCE; anaiś D 11 sārdhaṃ] <A85v> 12 bhagavataḥ] BCD; taḥ A, bhagavataṃ E • śirasābhivandyal BCDE; -vande A • bhagavantam] BCDE; bhagavaitam A • bhagavan] AB; bhagam CE, bhagavān D 13 mahatī] ACDE; mahati B • nāgaparșat] BCDE; -varșaṃ A - D includes saṃnipatitā | saparșat as a marginal addendum • $\quad$ saparșatsaparivārāḥ] DpcE; sarṣapanasaparivārāḥ A, sarṣapasaparivārāh $\mathrm{B}$, saparșatsuparivārāḥ C, saparivārāḥ Dac sāmagrībhāvena] $\mathrm{BCD}$; samayagībhāvena $A E 14$ paścime kāle paścime samaye] A; paścime kāle $B$, paścime samaye paścime kāle $\mathrm{CDE} \bullet$ sattvānāṃ] BD; sattvānāṃ sattvānāṃ ACE 15 -palāśān] corr.; -phalāśān ACDE, -phalāsāna $\mathrm{B} \quad 16$ nivārayișyāmah] $\mathrm{BCDE}$; nivāsayiṣyāmah $\mathrm{A}<\mathrm{B} 45 \mathrm{v}>$ 17 tṛ̣nagulmoṣadhisasyān virohayāmaḥ] ABCE omit this sentence 
twenty-one times, it should be offered ${ }^{158}$ at the time of lightning. The head of all harmful Nāgas burst. They will fall from the sky to the ground. This dhârañi is unobstructed everywhere."

[6.6] Then the Bhagavān praised the great Garuḍa Lord, ${ }^{159}$ Brahmā, Viṣnu and Maheśvara, "Well done, well done, O Great Brahmā, well spoken is this speech. A great spell is uttered. These dhärani-mantrapadas are established in Jambudvipa for the benefit, welfare and comfort of all beings. It is for the subduing and restraining of hostile and harmful Nāgas who do not have compassion and pity. It is for the giving of punishment to the enemy." 160

[6.7] Then Sāgara Nāga king, together with great Nāga kings of extraordinary kindness, energy and great supernatural power, headed by Samantākāraparikaracchatrākara Nāga king, and with other harmful Nāgas, numbering ten million million hundred thousands, approached the Bhagavān, went up to him and having bowed down with their heads at his feet addressed the Bhagavān, " $O$ Bhagavān, we have gathered as a great Nāga assembly. Together with our assemblies and retinues we will all completely protect all flowers, fruits, crops, leaves and foliage of all beings of Jambudvipa in the last time, in the last age. We will ward off all winds, thunderbolts, cold spells and heatwaves. We will send down rain showers duly at the proper time. We will grow grass, bush, herbs and crops. We will keep the vow of the Tathāgatas with our own assertion of the curse. We

158 Note that the Tibetan version gives "resounded", reflecting vāditavyam.

159 Note that Garuda has not been mentioned before in this chapter.

160 Para-daṇda may also mean "highest punishment." 
anupālayiṣyāmaḥ | sarvasattvānām āśāṃ paripūrṇamanorathā paripūrayiṣyāmaḥ | na vihiṃsayiṣyāmah | yadi bhagavan yathāyam kalparājāmantradhāraṇīpūrvoktāni guṇaviśeșāni atikrameyuh | mā ca vayam bodhim abhisambhotsyāmahe | ayaṃ śapathạ̣ |

tadyathā | oṃ țaki caki guli gumuli sasa gugu tịti viriți huyu huhu riṭi svāhā |

ayaṃ bhagavan nāgaśapathah | paścime kāle paścime samaye dușțanāgāśaniatiṿ̛șṭakālavṛștivātameghāśaniśītākālavāyuvidyutpātakāle ayaṃ śapatha vidyādhareṇa uccaśaraṇe vā parvate vā sapta vārān pūrvābhimukham uccasvareṇa uccārayitavyam | sarṣapaṃ parijapya caturdiśaṃ kṣeptavyam | sahakșiptenoccāritamātreṇa sarvanāgānāṃ śarīrāṇi śatadhā viśīryeyuh | vināśayeyuḥ | tmā bhavanti sațanti† | tatạ̣ śīghraṃ varṣadhārā-m-utș̣janti | bhagavatoktam ity evaṃ bhujagādhipate dhāraṇiyam iti |

[6.8] āryavajratuṇ̣a nāma samayakalparājaḥ parisamāptaḥ |

1 āśāṃ] C; āṃśā A, āśā BDE • paripūrṇamanorathā] BCDE; -tha A <A86r> 2 yathāyaṃ] <D67v> 4 bodhim] BCD; bodhimaṇde AE - abhisambhotsyāmahe] BCE; 'bhisambhotsyāmahe A, sambhotsyāmahe D <C1031u> 5 țaki] ACDE; uki B <E68(27)v $>$ caki] BCE; vaki AD • sasa] ACDE; suma B • viriți] BC; ciriți ADE • riți] ACDE; ciṭi B 6-8 D includes anāvṛștîakālavṛștivātameghāśaniśîtākālavāyuvidyutpātakāle ayaṃ śapatha vi as a marginal addendum

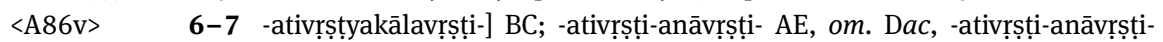
akālavrșți- Dpc • -ŝîtā-] em.; -līta- A, -śīta- BCD $p c$ E, om. Dac •-vidyutpāta-] BCDpcE; -vidyula- A, om. Dac 8 uccaśaraṇe] CDE; -śareṇe A, -śareṇa B • pūrvābhimukham] B; pūrvamukham A, pūrvāṅmukham CDE 9 sarșapam] $\mathrm{ABCE}$; sarșa D <B46r> • kṣeptavyam] DE; prakṣeptam A, +++ B, kṣeptavya C 10 sahakșiptenoccārita-] $\mathrm{AE}$; sahakșiptenauccārita- $\mathrm{BC}$, sahakșiptesahakșiptenauccārita- D 11 vināśayeyuḥ] BCDE; om. A • mā] BCDE; imāṃ A • sațanti] BC; satanti AE, sabhanti D 12 evaṃ] BCDE; āva A • bhujagādhipate] CD; bhujamgādhipate $\mathrm{AE}$, bhujagādhipateyam $\mathrm{B}<\mathrm{D} 68 \mathrm{r}>\quad 13$ nāma] $\mathrm{ACDE}$; nāma dhāraṇī $\mathrm{B}$ • parisamāptaḥ] D; samāptaḥ ABCE. C adds | śubham |, D adds | śubhamangalaṃ jagat | 
will fulfil the wishes of all beings satisfying their desires. We will not hurt them. O Bhagavān, if we neglect the special virtues taught previously in this ${ }^{161}$ mantradhäranī of the King of Manuals, may we not completely attain awakening. This is the curse:

“Namely, oṃ țaki caki guli gumuli sasa gugu țiți viriți huyu huhu riți svāhā.

"O Bhagavān, this is the Nāga curse. In the last time, in the last age, at the time of harmful Nāgas, thunderbolts, excessive rain, untimely rain, winds, clouds, thunderbolts, cold spells, untimely winds and lightning, this curse should be recited in a loud voice by the spell-master seven times, facing east, at an elevated dwelling ${ }^{162}$ or mountain. Having enchanted mustard seeds, these should be scattered in the four directions. Merely upon scattering and reciting, the bodies of all Nāgas crumble into a hundred pieces and perish. ${ }^{163}$ Then they send down rain showers quickly. This has been taught by the Bhagavān, $\mathrm{O}$ Serpent chiefs, you should keep it like that."

[6.8] The King of Ritual Manuals called Noble Vajra Beak Vow has ended.

161 Could ayam stand for asmin here?

162 Compare uccaśarana with uccasara [2.27] uccaśarasi, ūrdhvasarasi [4.1] and uccasthāna [1.13] [3.15] [5.6].

163 Note the cruxed Sanskrit here. The Tibetan translation gives "they will be obstructed." 
